\title{
Essays on the political economy of state government saving and the role of budget stabilization funds
}

\author{
Gary Albert Wagner \\ West Virginia University
}

Follow this and additional works at: https://researchrepository.wvu.edu/etd

\section{Recommended Citation}

Wagner, Gary Albert, "Essays on the political economy of state government saving and the role of budget stabilization funds" (1999). Graduate Theses, Dissertations, and Problem Reports. 1048.

https://researchrepository.wvu.edu/etd/1048

This Dissertation is protected by copyright and/or related rights. It has been brought to you by the The Research Repository @ WVU with permission from the rights-holder(s). You are free to use this Dissertation in any way that is permitted by the copyright and related rights legislation that applies to your use. For other uses you must obtain permission from the rights-holder(s) directly, unless additional rights are indicated by a Creative Commons license in the record and/ or on the work itself. This Dissertation has been accepted for inclusion in WVU Graduate Theses, Dissertations, and Problem Reports collection by an authorized administrator of The Research Repository @ WVU.

For more information, please contact researchrepository@mail.wvu.edu. 


\title{
Essays on the Political Economy of State Government Saving and the Role of Budget Stabilization Funds
}

\author{
Gary A. Wagner \\ Dissertation submitted to the \\ College of Business and Economics \\ at West Virginia University \\ in partial fulfillment of the requirements for the degree of \\ Doctor of Philosophy \\ in \\ Economics
}

\begin{abstract}
Russell S. Sobel, Ph.D., Chair
Ronald J. Balvers, Ph.D.

Anthony Davies, Ph.D.

Stratford M. Douglas, Ph.D.

George W. Hammond, Ph.D.

Department of Economics

Morgantown, West Virginia

1999
\end{abstract}

Keywords: Budget Stabilization Funds, Political Economy, Saving, Fiscal Policy

Copyright ( 1999 Gary A. Wagner 


\title{
ABSTRACT \\ Essays on the Political Economy of State Government Saving and the Role of Budget Stabilization Funds
}

\author{
Gary A. Wagner
}

This dissertation explores the saving behavior of state governments in the context of the ability of states to weather recessionary periods. The first chapter of the dissertation discusses the role of savings as a policy option for state decision-makers in light of the fiscal constraints facing state governments, reviews the previous literature that has examined the savings behavior of state governments, and outlines the research agenda for the dissertation. Chapter 2 provides statistics on the post-World War II savings of states to explore recent trends in their savings behavior and discusses the data employed in the dissertation. The third chapter examines an implication of the common pool problem associated with public sector savings by investigating how anticipated future changes in the controlling parties of states' legislatures affect the current level of saving. The results provide evidence that state saving is adversely impacted by future changes in controlling political parties, suggesting that politically unstable states may be ill-prepared to deal with recessions relative to politically stable states. Chapter 4 of the dissertation examines the role that political stability and other factors have had on states' choices to adopt budget stabilization funds. The results provide evidence that states which have experienced more long-term political instability, have been severely hit by recessions, and have expenditure and/or tax limitation laws in place, are more likely to adopt a budget stabilization fund as an additional vehicle for saving. The final research chapter of the dissertation investigates the effectiveness of budget stabilization funds by examining how states' savings behavior has changed as a result of utilizing budget stabilization funds. The results from this chapter provide evidence that budget stabilization funds governed by explicit deposit and withdrawal rules can assist state decision-makers in saving and thus enhance a state's ability to mitigate recessions in the future. Chapter 6 provides a summary of the dissertation and discusses areas of future research investigating state saving and budget stabilization funds. 


\section{ACKNOWLEDGMENTS}

I am indebted to my dissertation chair, Russell Sobel, for his guidance during this dissertation and throughout my tenure in graduate school. He has taught me more economics than I ever imagined, and his commitment to improving all aspects of my research and passion for economics served as a continuous source of motivation. My research abilities and understanding of economics will forever reflect his influence.

I would also like to thank my remaining committee members, Dr. Ronald Balvers, Dr. Stratford Douglas, Dr. George Hammond, and Dr. Anthony Davies, for their commitment to excellence. The advice and suggestions they provided greatly improved the quality of this dissertation.

I am also grateful to many individuals at Youngstown State University who provided me with outstanding guidance during my undergraduate education. I must first thank Keith Lepak for recognizing potential in me that I did not see in myself. I am also indebted to Tod Porter, Teresa Riley, Ebenge Usip, Dennis Petruska, Rochelle Ruffer, William Binning, David Porter, Paul Sracic, and David Pollack for their encouragement and belief in my ability to pursue graduate study.

Many thanks to Jean-Paul Szczyglowski and Patricia Papp, whose advice greatly enhanced my chances of success at graduate school.

A final thanks to my family, for without their continual faith this dissertation would have never become a reality. I am forever indebted to my parents, who through their actions more than their words taught me the meaning of commitment. 


\section{TABLE OF CONTENTS}

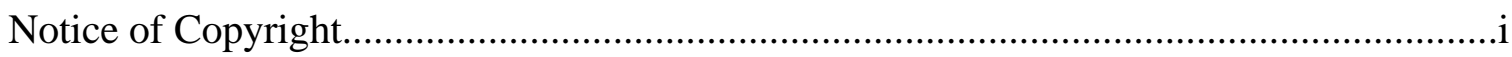

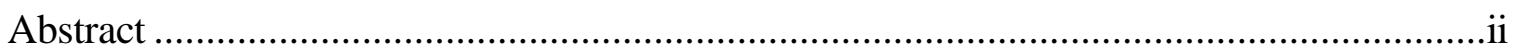

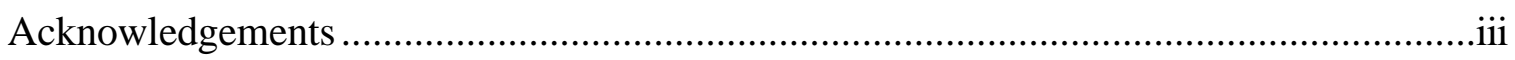

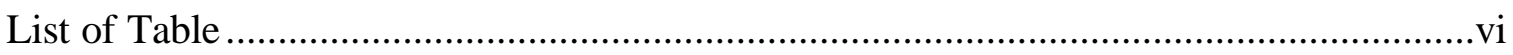

List of Figures ....................................................................................................vii

Chapter 1:

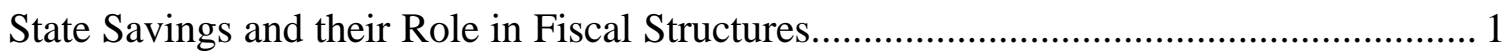

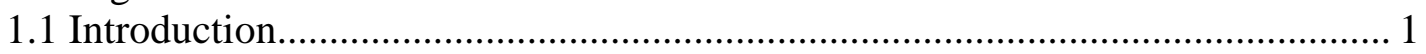

1.2 Fiscal Constraints Facing States' Decision-Makers ……….................................. 3

1.3 Previous Literature and Savings as a Policy Choice........................................... 10

1.4 Dissertation Research Agenda ....................................................................... 15

Chapter 2:

Recent Trends in the Savings Behavior of State Governments ....................................... 19

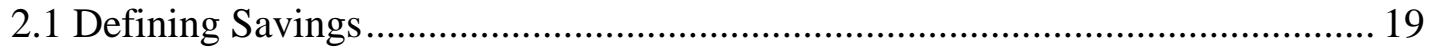

2.2 Facts and Figures Regarding States' Saving................................................... 21

2.3 Budget Stabilization Fund Data ……………………....................................... 31

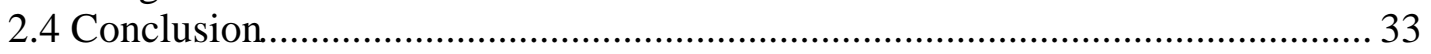

Chapter 3:

Political Control and Public Sector Savings: Life Cycle Evidence from the States ......... 35

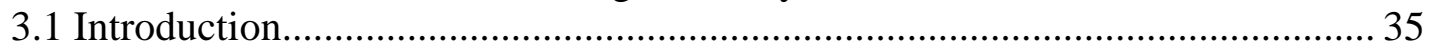

3.2 Previous Investigations of State Fiscal Behavior............................................... 38

3.3 Theoretical Treatment ............................................................................... 41

3.4 Specifying the Empirical Model and Data Description...................................... 50

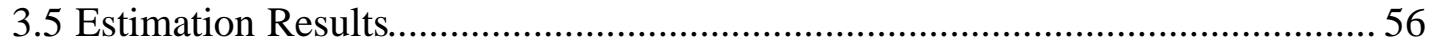

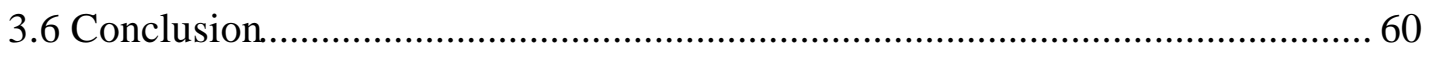

Chapter 4:

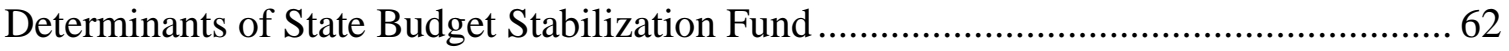

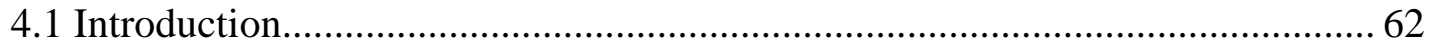

4.2 States' Reliance on Budget Stabilization Funds ................................................. 68

4.3 Empirical Methodology.............................................................................. 74

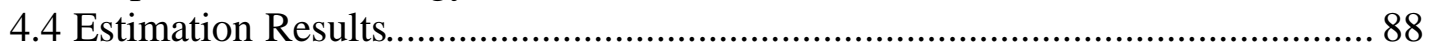

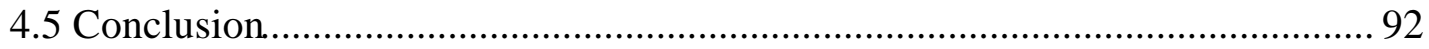




\section{Chapter 5:}

Are State Budget Stabilization Funds Only the Illusion of Savings? .......................... 95

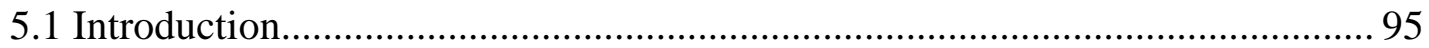

5.2 The Role of Budget Stabilization Funds in States' Saving.............................. 100

5.3 Estimating the Change between States' Pre-Budget Stabilization Fund and

Budget Stabilization Fund Savings Behavior...................................................... 108

5.4 The Role of Budget Stabilization Fund Characteristics in Influencing Savings

Behavior Changes ......................................................................................... 118

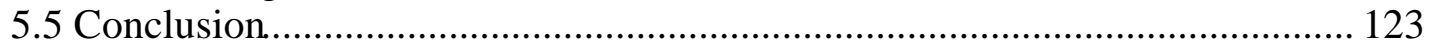

\section{Chapter 6:}

Conclusion and Prospects for Future Research................................................... 125

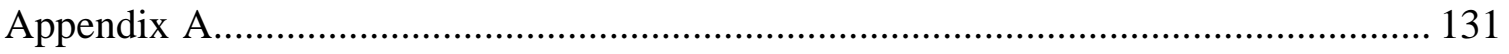

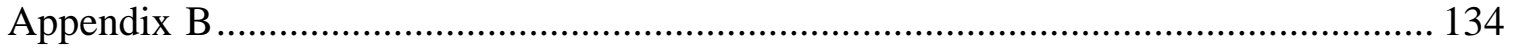

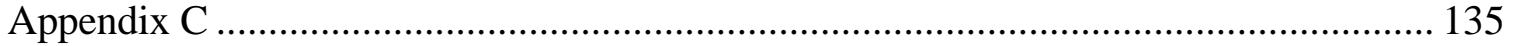

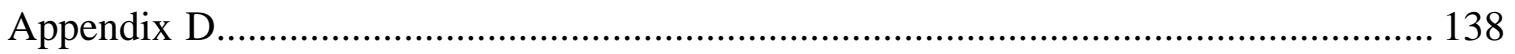

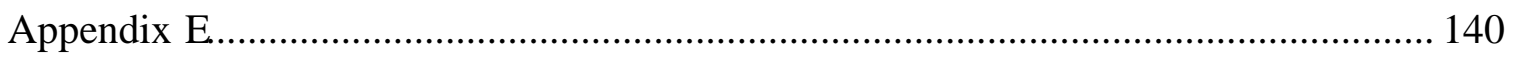

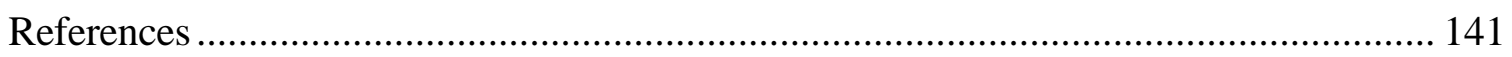




\section{LIST OF TABLES}

Table 1.1 - Summary of State Fiscal Constraints........................................................ 5

Table 2.1 - States' Average Current Savings Behavior 1945-1996................................. 23

Table 2.2 - States' Average Total Balances Behavior 1945-1996................................... 25

Table 2.3 - Summary of States' Budget Stabilization Fund Usage ................................. 30

Table 2.4 - Comparision of NASBO Reported Balances and Data

Obtained from Each State: Fiscal Year 1994 .............................................. 33

Table 3.1 - Variables Employed in Political Control Empirical Model........................... 52

Table 3.2 - Impact of Political Control on States' Current Savings ................................ 57

Table 4.1 - Adoption Dates of State Budget Stabilization Funds .................................. 71

Table 4.2 - Determinants of State Budget Stabilization Fund Adoption......................... 89

Table 5.1 - Structure of State Budget Stabilization Funds.......................................... 101

Table 5.2 - Budget Stabilization Fund Usage 1975-1996 .......................................... 107

Table 5.3 - Estimated Change in States' Savings Rates............................................. 114

Table 5.4 - Estimated Change in States' Total Balances........................................... 115

Table 5.5 - Impact of Budget Stabilization Fund Requirements on Estimated

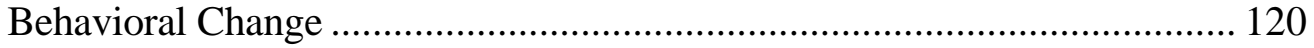




\section{LIST OF FIGURES}

Figure 2.1 - Average Per Capita Current Savings 1945-1996 …................................... 22

Figure 2.2 - Aggregate Total Balances as a Percentage of GDP 1950-1996 ................... 27

Figure 2.3 - Aggregate Total Balances and Aggregate Total Budget Stabilization Fund Balances 1945-1996.................................................................... 29

Figure 4.1 - Aggregate Budget Stabilization Fund Balances as a Percentage of

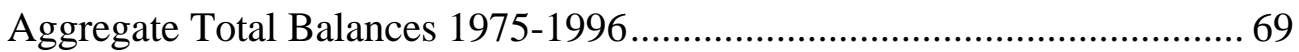

Figure 5.1 - Average Per Capita Budget Stabilization Fund Balances and Average Per Capita Total Balances 1975-1996.................................................... 106 


\section{Chapter 1}

\section{State Savings and their Role in Fiscal Structures}

\subsection{Introduction}

State governments are active savers. At the end of fiscal year 1996 aggregate reserve balances retained by states exceeded $\$ 19$ billion, or more than 0.6 percent of Gross Domestic Product. Despite its magnitude, very little research has been conducted to understand the savings behavior of state governments. This dissertation will attempt to answer several central questions regarding state savings and relate the implications to states' abilities to deal with fiscal crises.

This introductory chapter of the dissertation will discuss the role of savings as a policy option in the context of the fiscal constraints facing state governments and briefly outline the remaining chapters in the dissertation. Chapter 2 will focus on recent trends in the savings behavior of states and discuss the data used in the dissertation. Chapter 3 examines an implication of the 'common pool' problem associated with public sector savings by investigating how anticipated future changes in the controlling parties of states' legislatures affect the current level of savings. Chapter 4 of the dissertation examines the role that political, and other factors, has had on states' choices to adopt budget stabilization funds as an additional vehicle for saving. Chapter 5 investigates the effectiveness of budget stabilization funds as a means for saving by comparing states' pre-stabilization and post-stabilization fund savings behavior. In addition, Chapter 5 also investigates the role that specific stabilization fund characteristics have played in the behavioral change experienced by states since adopting a stabilization fund. Finally, Chapter 6 will conclude the dissertation by reviewing the conclusions and implications 
from each chapter and also discuss future prospects for research investigating states' savings.

States' use of savings is important as a means to help alleviate fiscal stress. According to a 1993 U.S. General Accounting Office survey of states, of the 32 states that had recently experienced budget deficits, nearly one-third of the aggregate deficit was correcting using savings. Although an investigation into the nature of state fiscal crises is interesting in its own right, such an investigation is not the primary focus of the dissertation. Holcombe and Sobel (1997), in their book Growth and Variability in State Tax Revenue: An Anatomy of State Fiscal Crises, have examined the causes of state fiscal crises in detail and it useful to briefly discuss their findings.

Broadly speaking, state fiscal stress is a situation in which the demands for state expenditures exceed the state's supply of revenue. While many factors contribute to a state's fiscal stress, Holcombe and Sobel note that there are sources of continuous fiscal stress and sporadic sources of fiscal stress. Continuous sources of state fiscal strain, such as the growth in Medicaid expenditures, various unfunded federal mandates, rising school enrollments, and reduced federal aid, contribute to state fiscal stress but are not the primary cause of state fiscal crises. ${ }^{1}$ According to Holcombe and Sobel, fluctuations in the growth of a state's revenue stream is the most influential factor affecting a state's fiscal health. Holcombe and Sobel note that such fluctuations in a state's revenue stream may come from two sources: fluctuations in the state's economy and fluctuations in the state's tax bases. Although states may reduce some cyclical variability in the growth of

\footnotetext{
${ }^{1}$ See Holcombe and Sobel (1997), Gold (1995), Poterba (1994), Dye and McGuire (1992), and Gramlich (1991) for a discussion of the causes of the state fiscal crisis of the early 1990s.
} 
their revenue streams by utilizing tax bases which are negatively correlated over the business cycle, states cannot completely remove the effects of cyclical fluctuations on revenue streams since they cannot diversify away market fluctuations. As a result, it is virtually impossible for states' decision-makers to know precisely when the next contraction will arise and exactly how their revenue streams will respond to that contraction.

\subsection{Fiscal Constraints Facing States' Decision-Makers}

The options available to a state's decision-makers to mitigate periods of fiscal stress and fiscal crises are limited by the state's institutional structure. ${ }^{2}$ Most states face a complex set of fiscal constraints. The most well known fiscal constraint facing state governments is balanced budget laws. Every state, with the exception of Vermont, is subject to some form of balanced budget rule. These laws can broadly be classified as ex ante and ex post balanced budget rules. The Advisory Commission on Intergovernmental Relations (ACIR, 1987) classifies state balanced budget rules into five categories: (1) the governor is required to submit a balanced budget; (2) the legislature is required to adopt a balanced budget; (3) the state may carry forward a budget deficit to be corrected in the next fiscal year; (4) the state may not carry forward a budget deficit into the next budget cycle (which is 2 years for the 20 states operating on a biennial cycle); and (5) the state may not carry forward a budget deficit into the next fiscal year. Categories (1) and (2) are examples of ex ante rules placing constraints on behavior prior to the fiscal year and do

\footnotetext{
${ }^{2}$ For a general overview of the role of institutions in influencing state fiscal behavior see Poterba (1996), Bohn and Inman (1996), and Knight and Levinson (1999b).
} 
not require any actions to remedy an end-of-the-year deficit. Category (3) permits perpetual debt finance so long as planned expenditures in the next fiscal year plus the current deficit do not exceed expected revenue. The final two categories, (4) and (5), at least theoretically force states to take some actions if an end-of-the-year deficit arises.

Despite the variation in balanced budget rules across states, most states' balanced budget laws are stock rather than flow in nature. ${ }^{3}$ Consequently, a majority of balanced budget laws do not prohibit deficits in a given fiscal year as long as the state has sufficient funds on hand to remedy the revenue shortfall. Thus, states that have accumulated sufficient reserve balances (savings) may run a deficit in any given fiscal year, thereby affording their decision-makers greater flexibility in dealing with periods of fiscal stress. Table 1.1, which summarizes each state's fiscal constraints in place as of 1998, illustrates each state's ACIR (1987) balanced budget classification(s).

Strong empirical evidence suggests that stringent balanced budget rules, such as categories (4) and (5), have more impact on state fiscal behavior than less stringent laws. Poterba (1994), using data from 1988-1992, finds that states with stringent balanced budget rules reduced per capita expenditures by $\$ 44$ in response to a $\$ 100$ per capita unanticipated budget deficit, as opposed to a $\$ 17$ reduction in per capita expenditures by states with weak balanced budget rules. In contrast though, Poterba finds no statistical difference between the per capita tax responses of states with strict balanced budget rules and states with weak balanced budget rules in response to a $\$ 100$ per capita unanticipated budget deficit. This suggests that states with strict balanced budget rules in place tend to

\footnotetext{
${ }^{3}$ See Gramlich (1991) for a discussion.
} 
Table 1.1 - Summary of State Fiscal Constraints

\begin{tabular}{|c|c|c|c|c|c|c|}
\hline State & $\begin{array}{c}\text { ACIR } \\
\text { BBR Category }\end{array}$ & $\begin{array}{c}\text { Expenditure } \\
\text { limitation law }\end{array}$ & $\begin{array}{c}\text { Tax limitation } \\
\text { law }\end{array}$ & $\begin{array}{c}\text { Supermajority } \\
\text { tax increase }\end{array}$ & $\begin{array}{l}\text { Referendum } \\
\text { debt approval }\end{array}$ & $\begin{array}{c}\text { Mandate } \\
\text { funding rule }\end{array}$ \\
\hline $\mathrm{AL}$ & 5 & & & & $\sqrt{ }$ & 1988 \\
\hline$\overline{\mathrm{AK}}$ & 1,3 & 1982 & & & $\sqrt{ }$ & \\
\hline$\overline{A Z}$ & 5 & 1978 & & 1992 & $\sqrt{ }$ & \\
\hline$\overline{\mathrm{AR}}$ & 5 & & & 1934 & & \\
\hline $\mathrm{CA}$ & 1,3 & 1979 & & 1979 & $\sqrt{ }$ & 1973 \\
\hline $\mathrm{CO}$ & 5 & 1991,1992 & 1992 & 1992 & $\sqrt{ }$ & 1981 \\
\hline$\overline{\mathrm{CT}}$ & $1,2,3$ & 1991,1992 & & & & \\
\hline$\overline{\mathrm{DE}}$ & 5 & 1978 & & 1980 & & \\
\hline FL & 5 & & 1994 & 1971 & & 1978 \\
\hline GA & 5 & & & & $\sqrt{ }$ & \\
\hline $\mathrm{HI}$ & $1,4,5$ & 1978 & & & & 1979 \\
\hline ID & 5 & 1980 & & & $\sqrt{ }$ & \\
\hline $\mathrm{IL}$ & 1,2 & & & & & 1981 \\
\hline IN & 5 & & & & $\sqrt{ }$ & \\
\hline IA & 5 & 1992 & & & $\sqrt{ }$ & \\
\hline $\mathrm{KS}$ & 5 & & & & $\sqrt{ }$ & \\
\hline KY & 4,5 & & & & $\sqrt{ }$ & \\
\hline LA & 2 & 1993 & 1979 & 1966 & & 1991 \\
\hline $\mathrm{ME}$ & 5 & & & & $\sqrt{ }$ & 1992 \\
\hline $\mathrm{MD}$ & $1,2,3$ & & & & & \\
\hline MA & 1 & & 1986 & & & 1981 \\
\hline $\mathrm{MI}$ & 3 & & 1978 & & & 1979 \\
\hline $\mathrm{MN}$ & 4 & & & & $\sqrt{ }$ & \\
\hline $\mathrm{MO}$ & 5 & & 1980,1996 & & $\sqrt{ }$ & 1980 \\
\hline MS & 5 & 1992 & & 1970 & $\sqrt{ }$ & \\
\hline MT & $2,4,5$ & 1981 & & & & 1974 \\
\hline $\mathrm{NE}$ & 5 & & & & $\sqrt{ }$ & \\
\hline $\mathrm{NV}$ & 1,2 & 1979 & & & & 1993 \\
\hline $\mathrm{NH}$ & 1 & & & & & 1984 \\
\hline NJ & 5 & 1990 & & & $\sqrt{ }$ & \\
\hline NM & 5 & & & & $\sqrt{ }$ & 1984 \\
\hline $\mathrm{NY}$ & 1 & & & & & \\
\hline $\mathrm{NC}$ & 5 & 1991 & & & & \\
\hline ND & 4 & & & & $\sqrt{ }$ & \\
\hline $\mathrm{OH}$ & 5 & & & & $\sqrt{ }$ & \\
\hline $\mathrm{OK}$ & 5 & 1985 & & 1992 & & \\
\hline OR & 4 & 1979 & & 1996 & $\sqrt{ }$ & \\
\hline PA & $1,2,3$ & & & & & \\
\hline RI & 5 & 1992 & & & $\sqrt{ }$ & 1979 \\
\hline $\mathrm{SC}$ & 3,5 & 1980,1984 & & & $\sqrt{ }$ & 1993 \\
\hline SD & 5 & & & 1978 & $\sqrt{ }$ & 1978 \\
\hline TN & 3,5 & 1978 & & & & \\
\hline TX & 2,4 & & & & $\sqrt{ }$ & \\
\hline UT & 5 & 1989 & & & $\sqrt{ }$ & \\
\hline \multicolumn{7}{|l|}{ VT } \\
\hline VA & 4 & & & & $\sqrt{ }$ & \\
\hline WA & 3 & 1993 & & 1993 & $\sqrt{ }$ & 1980 \\
\hline WV & 5 & & & & $\sqrt{ }$ & \\
\hline WI & 3 & & & & $\sqrt{ }$ & \\
\hline $\mathrm{WY}$ & 4 & & & & $\sqrt{ }$ & \\
\hline
\end{tabular}

Sources: ACIR (1987), NCSL (1998), Kiewiet and Szakaly (1996), Knight (1998a), and Knight (1998b). 
rely more heavily on expenditure reductions to remedy unexpected deficits than do states with ex ante balanced budget rules.

In addition, Poterba also finds that states with strict balanced budget rules adjust both expenditures and taxes to account for more than the unexpected budget deficit (a $\$ 120$ per capita adjustment for every $\$ 100$ per capita unexpected deficit), while states with less stringent balanced budget rules adjust expenditures and taxes to mitigate only $\$ 79$ of every $\$ 100$ per capita unexpected budget deficit. Moreover, Bohn and Inman (1996) find that states with strict balanced budget rules have a lower annual average probability of running a budget deficit than do states with weak balanced budget rules.

Given this evidence that states with strict balanced budget rules face budget deficits less frequently and respond more vigorously to deficits than states with weak balanced budget rules, one might expect states with strict balanced budget rules to experience more volatile business cycles. Bohn and Inman (1996), using a panel of 47 states over the period from 1970 to 1991, find no statistical difference between the business cycle volatility of states with strict balanced budget rules and states with weak balanced budget rules. Bohn and Inman explain the lack of increased business cycle volatility for states with stringent balanced budget rules as being dependent on states' savings. They find, on average, that states with strict balanced budget rules save about $\$ 100$ per capita more than states with weak balanced budget rules, which is consistent with the findings of Alt and Lowry (1994). Moreover, Bohn and Inman also find that states with strict balanced budget rules also experience significantly less cyclical volatility in their savings than states with weak balanced budget rules. Thus, Bohn and Inman assert that states with strict balanced budget rules may use savings as a means to 
ensure that fiscal limits do not bind, thereby limiting fluctuations that may be caused by prohibiting budget deficits.

While the estimates of Poterba (1994) indicate that states rely on expenditure reductions and tax increases to mitigate unanticipated shocks, the GAO's (1993) study seems to indicate that states consider savings to be a vital policy tool. From the standpoint of a state's decision-makers, research also suggests that savings may dominate both expenditure reductions and tax increases as a policy option. Using state level data from 1990 and 1991, Sobel (1998) finds that both expenditure reductions and tax increases significantly increased states' legislative turnover rates. Thus, states' decisionmakers may have an incentive to maintain fungible balances as an alternative to expenditure reductions and/or tax increases for the purpose of weathering recessions.

States also use many outlets other than savings during periods of fiscal stress in an effort to remedy revenue shortfalls. Aside from accounting gimmicks, such as accelerating tax collections and deferring payments between fiscal years to temporarily delay a deficit, many states rely partly on debt to remedy short-run fiscal stress. While only 9 states prohibited issuing any guaranteed debt in 1990, most states required either voter approval or supermajority legislative approval to issue guaranteed debt (Kiewiet and Szakaly, 1996). In terms of non-guaranteed debt such as revenue bonds, only 15 states had any limits in place in 1990 (Kiewiet and Szakaly, 1996). States that required voter approval to issue debt in 1990 are cited in Table 1.1.

Not surprisingly, von Hagen (1991), Bunch (1991), and Kiewiet and Szakaly (1996) find that states with more stringent restrictions on the issuance of guaranteed debt, such as constitutional restrictions limiting the quantity of debt and voter approval, issue 
less general obligation debt and more revenue debt than states that do not require voter approval to issue debt or have weak constitutional debt restrictions. In addition, Kiewiet's and Szakaly's finding that total per capita outstanding debt of states which strictly limit general obligation debt is statistically smaller than the total per capita debt of states which do not limit general obligation debt provides evidence that restricting general obligation debt has caused states to reduce the quantity of debt issued. While much of the nonguaranteed debt issued by states is not subject to constitutional or statutory limits, and thus may be potentially useful as a source of revenue in lean times, the fact that nonguaranteed debt generally pays a higher rate of interest may actually increase the degree of fiscal strain states feel over time if non-guaranteed debt is continuously utilized as a policy choice (Forbes, Fischer, and Peterson, 1981). Moreover, Bohn and Inman (1996) find that capital investment is lower for states with strict balanced budget rules than for states with weak rules, which they claim indicates that states with strict balanced budget rules are using non-guaranteed debt at the expense of capital investment to finance state expenditures.

Thus, while some states appear to use debt as means to finance expenditures in the short-run, the use of savings as a policy option may also dominate the issuance of debt. Since bond rating agencies, such as Moody's and Standard and Poor's, consider all fungible monies and outstanding debt when rating state bonds, states with higher levels of total debt (both guaranteed and non-guaranteed) and smaller surpluses (savings) may find themselves faced with increasing costs for capital investment if the state's bond ratings are lowered. Thus, the issuance of debt as a policy option may not only increase future fiscal strain, it may also increase the cost of capital investments, which may be 
particularly adverse for states already experiencing reduced capital investments as a result of fiscal limits.

In addition, many states' decision-makers are faced with the existence of tax and expenditure limitation laws designed to limit the growth in the state's spending and/or tax revenue. In general, tax and expenditure limitation laws specify the maximum increase in the rate of growth in the state's tax revenues and expenditures from one year to the next. The limits vary widely across states but are typically based on the growth in real personal income or population growth plus inflation. The year each state adopted their expenditure and/or tax limitation law is provided in Table 1.1 .

The evidence of the effectiveness of tax and expenditure limitation laws has been mixed, but generally illustrates that such laws have been binding. Cross-sectional studies by Abrams and Dugan (1986), Cox and Lowery (1990), and Bails (1990) all find that tax and expenditure laws are not significant in influencing states' fiscal behavior. However, more complex time-series or panel studies by Dugan (1988), Stansel (1994), Ruben (1995), and Elder (1992) suggests that expenditure limitation laws, but not tax limitation laws, have influenced states' fiscal behavior. All of the time-series and/or panel studies find evidence that the enactment of expenditure limitation laws significantly reduces the growth in government spending. Elder (1992) also finds that the growth in tax revenue is significantly lower as a result of expenditure limitations, but that tax revenue growth is independent of tax limitation laws. Moreover, Poterba (1994) finds that states with expenditure and tax limitation laws in place increase taxes less than states without such laws in response to a $\$ 100$ per capita unanticipated budget deficit. 
While the empirical evidence supports the notion that expenditure limitation laws have more influence than tax limitation laws, a tax limitation law may still have a dramatic impact on a state's ability to raise revenue during a recession since decisionmakers will be constrained in how much they can increase taxes.

Another potential barrier to raising revenue is the existence of supermajority voting rules that require approval of two-thirds of a state's decision-makers in order to increase taxes. Knight (1998a), using an instrumental variables approach to account for the potential endogeneity of supermajority rules, finds that states which require supermajorities for tax increases have a significantly lower average tax rate than states that do not require a legislative supermajority.

Finally, to satisfy fiscal constraints many states have followed the model of the federal government and have shifted financial responsibility to local governments and often do not provide funds necessary to meet such obligations. While 19 states require mandates given to local governments be fully funded, the majority do not (Knight, 1998b). Thus, states may shift the financial burden of some services to local governments and bear little or no expense. States that possess mandate funding requirements are provided in Table 1.1, denoting the year in which the rule was adopted.

\subsection{Previous Literature and Savings as a Policy Choice}

The usefulness of savings as policy option during periods of depressed revenue requires that states actually do save. Traditionally, state savings took the form of surplus balances in the state's general fund account. A state's general fund account is an account from which expenditures can be made to finance any good or service at the discretion of the 
legislature. All states earmark at least a fraction of their revenue, often having separate accounts for specific expenditures, so surplus funds retained by a state in any account are typically transferred to the state's general fund. Monies held in the state's general fund may accumulate over time, but in terms of state accounting practices general fund balances are non-accumulating balances. This means that at the end of any given fiscal year surplus funds are automatically treated as revenue in the next fiscal year. Thus in order for general fund surpluses to exist in times of fiscal stress, states' decision-makers must possess the fiscal discipline to resist spending surplus balances during expansionary periods.

In recent decades however, states have begun to rely more heavily on budget stabilization funds as an additional vehicle for saving. A budget stabilization fund, often referred to as 'rainy day fund,' is an account separate from the state's general fund in which typically a fraction of general fund surplus balances are retained. ${ }^{4}$ Prior to the recession of the early 1980s only 10 states utilized budget stabilization funds, but that number has grown to 44 by the end of 1998 and the legislatures of Oregon and Illinois considered legislation to adopt reserve accounts during $1998 .{ }^{5}$ A state's ability to use savings to mitigate fiscal stress will be dependent on the funds available from the state's

\footnotetext{
${ }^{4}$ Unlike general fund accounts, which are treated as revenue in the coming fiscal year, the accounting convention with stabilization funds is that the monies held in the fund are left to accumulate over time. Thus, stabilization fund balances are not automatically treated as a component of future revenue.

${ }^{5}$ Information regarding Oregon's and Illinois' consideration of a budget stabilization fund can be found on the Internet at http://www.ost.state.or.us/news/eedbudstab_02031999.htm [Accessed 23 July 1999] and http://www.ioc.state.il.us/FiscalFocus/ffmenu.cfm [Accessed 23 July 1999] in the February/March 1999 edition.
} 
general fund and budget stabilization fund since their sum is the total quantity of fungible balances available to a state at the end of any fiscal year.

In a broader sense, state budget stabilization funds are essentially self-insurance schemes aimed at providing states with a source of fungible balances to deal with unanticipated shocks. During the 1970s the federal government developed a countercyclical revenue sharing plan, enacted by the Public Works Employment Act of 1976, that was designed to compensate state and local governments for losses in revenue growth resulting from recessions. The program would provide funds to state and local governments when the seasonally adjusted national unemployment rate exceeded some target value, and the allocation of these funds across states depended on the total funds available (which was linked to the difference between the national unemployment rate and the target unemployment rate) and individual state unemployment rates. Vogel and Trost (1979) examined the counter-cyclical revenue sharing program and argued that states would benefit very little for several reasons. First, they argued that the use of the national unemployment rate and state unemployment rates to allocate funds is not precisely linked to states' revenue growth. Next, the funds provided by the federal government were likely to be much less than the revenues lost by states. Finally, there was likely to be long lags between the end of the recession and the disbursement of funds.

The notion of insuring states against contractions received little attention in the years following Vogel and Trost (1979), and the counter-cyclical revenue sharing program was rescinded in 1984. However, the recent formation of the European Monetary Union (EMU) has once again propelled public sector insurance schemes to the 
forefront of economic research ${ }^{6}$ Much of this recent literature focuses on the possible advantages and disadvantages of risk pooling between states (or countries in the case of the EMU) and the role that regional insurance may play. While state budget stabilization funds can be thought of as "counter-cyclical self-insurance" for mitigating recessionary periods, I do not explore the potential benefits to states from risk pooling or forming regional stabilization funds. However, the notions of political control resulting from the public sector common pool problem examined in Chapter 3 and the role that stabilization fund rules play in states' gains to savings explored in Chapter 5 apply to the broader literature which has investigated risk pooling and regional insurance among the U.S. states and EMU nations.

The research investigating the savings behavior of state governments has tended to focus on the role of budget stabilization funds in assisting states' efforts to save rather than on the role of savings to mitigate fiscal stress. However, in examining the state fiscal crisis of the early 1990s, Sobel and Holcombe (1996a) calculate the degree of fiscal stress experienced by states. Measuring fiscal stress as the amount of expenditure reductions plus the amount of discretionary tax increases less their long-run trend in expenditures, they compute the quantity of savings each state would have needed to have on hand to maintain their long-run expenditure growth rate throughout the recession without relying

\footnotetext{
${ }^{6}$ The use of a single currency in the EMU nations essentially eliminates individual countries from utilizing monetary policy as a tool to deal with asymmetric shocks, thereby leaving fiscal policy as the primary tool. Thus, investigations focusing on regional or state-specific stabilization funds to deal with both symmetric and asymmetric shocks should be particularly fruitful in coming years. For recent research exploring regional insurance schemes in the U.S. see Athanasoulis and Wincoop (1998), Asdrubali, Sorenson, and Yosha (1996), and Sorenson and Yosha (1997). For investigations in regional risk sharing in the EMU see von Hagen (1998), von Hagen and Hammond (1998), and Sorenson and Yosha (1998).
} 
on increasing taxes for additional revenue. They find that only Kansas and Hawaii had sufficient savings to maintain their long-run growth in expenditures throughout the recession without any need for tax increases. The states in the worst savings position, as calculated by Sobel and Holcombe, were Alaska and Connecticut. Both states had accumulated savings less than 20 percent of what was needed to maintain expenditure growth without relying on tax increases.

While Sobel's and Holcombe's investigation is suggestive that states may not save enough, the optimal quantity of savings is dependent on the preferences of the state's decision-makers. It may be the case that states' decision-makers desire to reduce expenditure growth and/or increase taxes to some extent during slowdowns rather than relying solely on savings. In an editorial addressed to the State of Oregon regarding the adoption of a budget stabilization fund, Oregon State Treasurer Jim Hill stated that "this is not to say that a reserve fund makes the state recession proof; it does not. However, it does give the state some breathing room during recession to craft a reasonable, solution to the problem."7

Research that has investigated budget stabilization funds does suggest that states' fiscal health has improved as a result of utilizing budget stabilization funds. Examining the impact that stabilization funds had on states' abilities to cope with fiscal stress during the 1990-1991 recession, Sobel and Holcombe (1996a) find that states with budget stabilization funds experienced fewer reductions in expenditures below their long-run growth rate than did states without stabilization funds. Sobel and Holcombe also find that

\footnotetext{
${ }^{7}$ Jim Hill's Opinion/Editorial was accessed online at http://www.ost.state.or.us/ews/eedbudstab_02031999.htm [Accessed 23 July 1999].
} 
states whose stabilization funds had explicit deposit requirements experienced significantly less fiscal stress than states whose budget stabilization funds did not contain such requirements. More recently, Knight and Levinson (1999a), using a panel of data from 1984-1997, find that states with budget stabilization funds save more than states without budget stabilization funds (but the difference is not statistically significant), and that total savings increases with the adoption of stabilization funds. In addition, states with budget stabilization funds have been found to experience less volatile business cycles than states which do not have budget stabilization funds (Levinson, 1998).

\subsection{Dissertation Research Agenda}

While the limited research investigating the savings behavior of state governments does suggest that savings and budget stabilization can be effective policy tools, many unanswered questions remain. The dissertation will provide new insights into understanding the savings behavior of states by examining several aspects of states' savings behavior.

Before proceeding to the research chapters, Chapter 2 presents and discusses some descriptive data regarding the post-World War II savings behavior of state governments. Included in Chapter 2 is a discussion concerning states' use of budget stabilization funds in recent decades.

An issue in public sector saving which has thus far been untouched in the literature is the common pool problem associated with savings. Since the right to access and allocate the common pool of a state's savings is granted to the political party or coalition which controls the political outcome, a state's savings may be adversely affected 
by an anticipated change in the controlling party. If decision-makers currently controlling the political outcome expect to lose their ability to control outcomes in the future, then they may opt to increase current spending and reduce current savings while they are still guaranteed control over the allocation of funds. Chapter 3 investigates this implication of the common pool problem by developing a theoretical model which describes why a representative legislator will opt to increase current spending, thereby reducing current saving, when his prospects for controlling future political outcomes diminish. An empirical model, which is based on the theoretical model in Chapter 3, is estimated to test this implication of the common pool problem. I find strong evidence in support of the notion that states' legislators opt to increase current spending and reduce current saving when a change in the future controlling party of a state's lower house is expected. The implication of this finding is that public sector savings may be systematically adversely impacted by anticipated changes in political control. Thus, states that are more politically unstable than other states will be less prepared to deal with periods of fiscal stress, all other factors constant.

While political manipulation of states' savings by legislators for self-gain is possible due to the common pool problem, budget stabilization funds have the potential to provide states with a vehicle for saving than can lessen the common pool problem. In states' general fund accounts, a simple majority vote of the state's legislators is all that is required (along with executive approval) to allocate funds. With budget stabilization funds, states can reduce political manipulation of savings by placing restrictions on the manner in which funds are to be allocated to and from the stabilization fund. In essence, political manipulation of states' savings resulting from changes in political control is a 
short-run problem since a one-time anticipated change in the controlling parties will adversely affect only the current level of savings. Systematic political manipulation of states' saving resulting from changes in political control is more of a long-run problem. States which experience systematic changes in their controlling parties over a long period of time should, on average, save less than states which are more politically stable, ceteris paribus. Since saving funds may be beneficial to all legislators because it reduces the need to rely on expenditure cuts and tax increases, decision-makers in states which have witnessed more systematic political instability will have more to gain from saving than decision-makers in states which have been politically stable. Thus, decision-makers in states which have experienced systematic political instability may be more likely to adopt a budget stabilization fund as a solution to the long-term problems with political control resulting from the common pool problem.

Chapter 4 examines the determinants of state budget stabilization fund adoption to investigate the role that various political and economic factors have had on states' choices. Estimating an empirical model consisting of 46 states over the period from 1945 to 1996 , I find evidence consistent with the notion that states which have experienced more political instability over the long-run are more likely to adopt stabilization funds, all other factors constant. I also find strong evidence that states hit more severely by recessions are more likely to adopt budget stabilization funds, ceteris paribus. Moreover, I find that states that have expenditure and tax limitation laws in place are also more likely to adopt budget stabilization funds, suggesting that some states adopted stabilization funds as a means to circumvent the fiscal restrictions adopted during the 'tax revolt' of the late 1970s and early 1980s. 
The final research chapter examines the effectiveness of budget stabilization funds in aiding states' savings. While research by Sobel and Holcombe (1996a) and Knight and Levinson (1999a) suggest that budget stabilization funds have enhanced states' fiscal health, these studies have been restricted to examining states' uses of stabilization funds only after 1983 due to data limitations. Using data obtained from each state over their entire history of stabilization fund usage, I estimate an intervention model for each state separately to examine how the state's average rate of saving and average total balances have changed as a result of adopting a budget stabilization fund. I find that one state has experienced a significantly higher average rate of saving after adopting a stabilization fund, but more than one-third of states have experienced significantly higher average total balances after adopting funds. This provides very strong evidence that the states that have benefited from stabilization funds have not done so by saving more in a given year, rather they have benefited by retaining the funds that they do save longer. Moreover, I also find evidence that the structure of state budget stabilization funds plays a very large role in the gains to savings experienced by states. Specifically, I find that states whose stabilization funds contain explicit deposit and withdrawal rules are much more likely to enhance their fiscal health, and thus their ability to mitigate recessions, than are states whose budget stabilization funds are governed solely at the discretion of the state's legislature.

Finally, Chapter 6 concludes the dissertation. The methodology and importance of each chapter are reviewed in the context of the policy implications from each chapter for states' abilities to deal with fiscal crises. The concluding chapter also provides prospects for future areas of research regarding states' savings and budget stabilization funds. 


\section{Chapter 2}

\section{Recent Trends in the Savings Behavior of State Governments}

\subsection{Defining Savings}

As alluded to in the introduction, states have long been active savers. The fiscal constraints facing states' decision-makers allow states to save surplus funds that can then be allocated in the future. To understand the nature of states' savings behavior it is necessary to make a distinction between two definitions of savings used throughout the dissertation.

Most states rely on both general fund balances and budget stabilization fund balances as their source of reserve balances. While monies retained in the state's general fund may accumulate over time, for the state's accounting purposes general fund surpluses are non-accumulating funds. This means that any fiscal-year-end general fund surplus at time $t$ becomes a component of the state's general fund revenue at time $t+1$. Hence, if Ohio has a $\$ 100$ million surplus in the state's general fund at the end of fiscal year 2000 and forecasts general fund revenue in fiscal year 2001 to be $\$ 1$ billion, the state's decision-makers would plan their level of expenditures in fiscal year 2001 using a revenue expectation of $\$ 1.1$ billion rather than $\$ 1$ billion.

In contrast to general fund surpluses, monies retained in the state's budget stabilization fund are accumulating balances, which means that these funds are not automatically treated as revenue in the upcoming fiscal year. Thus, states' decisionmakers do not typically plan future expenditures based upon the state's balance in their budget stabilization fund. Hence the common definition of savings, which is current revenue less current expenditures, can be obtained for a given state at time $t$ by summing 
the change in the state's general fund position between time $t$ and $t-1$ and the change in the state's budget stabilization fund position between time $t$ and $t-1$. This definition is referred to as a state's current savings in the dissertation. This definition of savings is examined in Chapter 3 when I study how political control influences states' current savings. In addition, this definition is also employed in Chapter 5 as I investigate how the rate at which states save annually has changed as a result of utilizing budget stabilization funds.

An additional measure of a state's fiscal health is the total quantity of fungible balances available at time $t$. As Gold (1995) notes, the total quantity of fungible balances available to a state at any given time is perhaps the best indicator of the state's fiscal position since a state's ability to mitigate periods of fiscal stress will be dependent upon such balances. This definition of 'savings', which is referred to as the state's total balances in the dissertation, is the public sector analog to the consumer definition of wealth. Essentially a state's current savings is a flow measure of savings while the state's total balances is a stock measure of savings. Chapter 5 investigates how states' total balances have changed as a result of enacting budget stabilization funds. Moreover, previous investigations of the savings behavior of state governments, undertaken by Sobel and Holcombe (1996a) and Knight and Levinson (1999a), examined states' total balances rather than states' current savings. 


\subsection{Facts and Figures Regarding States' Saving}

Now that the distinction between a state's current savings and a state's total balances has been introduced, it is useful to examine the magnitude and recent trends in state government savings.

As is evident from Figure 2.1, which plots the average per capita current savings by states over the period from 1945-1996, the average per capita current savings behavior of states has been somewhat volatile. As one would expect, average per capita current savings tends to fall during, or just following, economic contractions. ${ }^{8}$ The fact that annual contributions to total balances decreases (and is often negative) is not surprising given that states' tax bases tend to contract during recessions leaving states' decisionmakers in need of fungible balances to maintain expenditure growth.

Moreover, it is also apparent from Figure 2.1 that the average per capita current savings of states has tended to increase following recessions. The most pronounced increases in average per capita current savings occurred in 1962, 1970, 1976, 1983, and 1993, all of which immediately followed contractions. Given that states often increase taxes during recessions to increase revenue, it is not surprising that current savings tends to rise following recessions since tax bases tend to expand during recoveries and states often do not remove the tax increases instituted during contractions. This combination of higher tax rates and expanding bases often results in a windfall of revenue for states (Mattoon and Testa, 1992). This practice of increasing current savings immediately

${ }^{8}$ The National Bureau of Economic Research (NBER) recession dates appearing in Figure 2.1 include 1945, 1949, 1953-1954, 1957-1958, 1960-1961, 1969-1970, 19731975, 1980-1982, and 1990-1991. In addition, Alaska is excluded from Figure 2.1 due to its extremely volatile current savings behavior. 


\section{Figure 2.1 - Average Per Capita Current Savings 1945-1996}

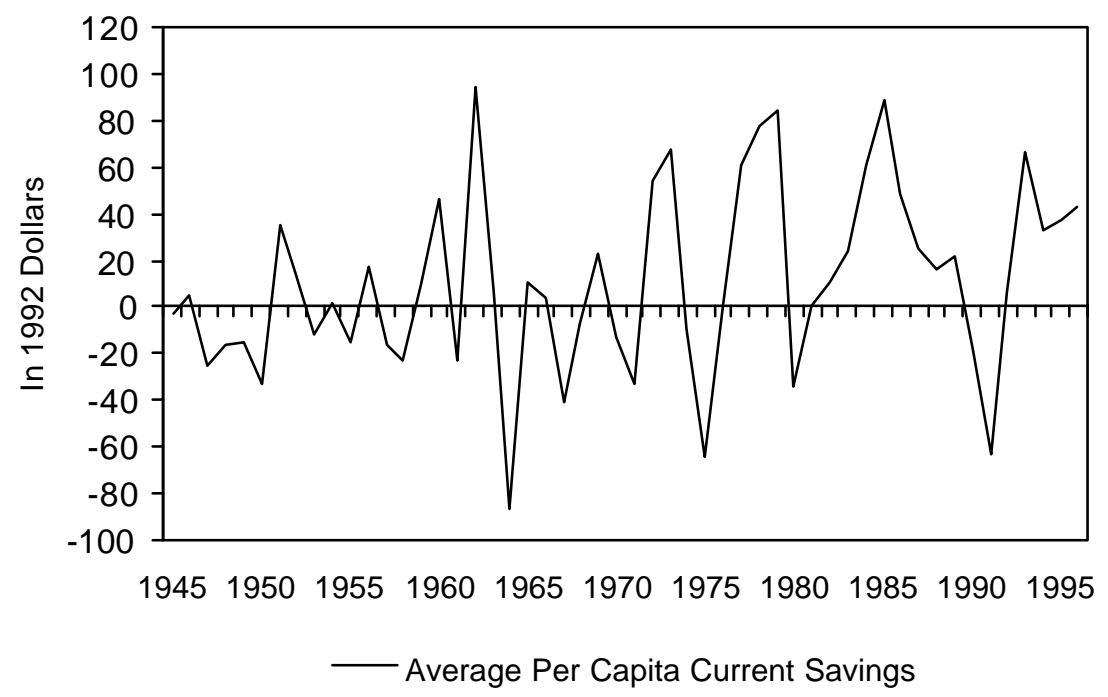

Notes: Excludes Alaska.

following a recession may be interpreted as prudent behavior by states' decision-makers since states are often left with very few reserve balances by the beginning of the recovery phase (Mattoon and Testa, 1992). Thus, it seems that the trend in the current savings behavior of states is to expand their fungible balances immediately following contractionary phases since their reserve balances are likely to be depleted as a result of the recession.

While Figure 2.1 provides average information regarding the current savings behavior of all states, the average per capita current savings of each state is provided in Table 2.1. On average, the majority of states have contributed to total balances rather than dissaving during the post-war era. In fact, 80 percent of states have averaged positive current savings, while only 10 states have averaged dissaving over this period. The largest average dissaver in the post-war period has been Louisiana, averaging an annual deficit of $\$ 3.33$ per person. The state averaging the greatest contributions to 
current savings has been Alaska, saving more than $\$ 118$ per person each year. While this figure is much larger in magnitude than the second largest saving state (which is Delaware at just over $\$ 10$ per person), the figure for Alaska should be interpreted with caution. The State of Alaska is unique regarding fiscal behavior in the sense that the state receives very large royalties from the oil industry making it essentially an outlier when compared to other states.

Table 2.1 - States' Average Current Savings Behavior 1945-1996

\begin{tabular}{|c|c|c|c|c|c|}
\hline State & $\begin{array}{c}\text { Average } \\
\text { Per Capita } \\
\text { Savings }\end{array}$ & $\begin{array}{c}\text { Average } \\
\text { Savings as a } \\
\% \text { of } 1996 \\
\text { Revenue }\end{array}$ & State & $\begin{array}{l}\text { Average } \\
\text { Per Capita } \\
\text { Savings }\end{array}$ & $\begin{array}{c}\text { Average } \\
\text { Savings as } \\
\text { a \% of } \\
1996 \\
\text { Revenue } \\
\end{array}$ \\
\hline Alaska & $\$ \$ 118.92$ & $0.66 \%$ & Montana & \$\$0.74 & $0.04 \%$ \\
\hline Alabama & $-\$ 0.91$ & $-0.03 \%$ & North Carolina & $\$ 1.96$ & $0.09 \%$ \\
\hline Arkansas & $\$ 3.56$ & $0.13 \%$ & North Dakota & $\$ 6.50$ & $0.21 \%$ \\
\hline Arizona & $\$ 1.10$ & $0.05 \%$ & Nebraska & $\$ 2.11$ & $0.08 \%$ \\
\hline California & $-\$ 1.39$ & $-0.01 \%$ & New Hampshire & $-\$ 2.86$ & $-0.08 \%$ \\
\hline Colorado & $\$ 2.01$ & $0.07 \%$ & New Jersey & $\$ 1.70$ & $0.06 \%$ \\
\hline Connecticut & $\$ 3.49$ & $0.11 \%$ & New Mexico & $\$ 5.24$ & $0.07 \%$ \\
\hline Delaware & $\$ 10.07$ & $0.26 \%$ & Nevada & $\$ 3.46$ & $0.12 \%$ \\
\hline Florida & $-\$ 0.61$ & $-0.01 \%$ & New York & $\$ 1.85$ & $0.05 \%$ \\
\hline Georgia & $\$ 0.14$ & $0.002 \%$ & Ohio & $\$ 3.15$ & $0.14 \%$ \\
\hline Hawaii & $\$ 1.93$ & $0.08 \%$ & Oklahoma & $\$ 2.52$ & $0.09 \%$ \\
\hline Iowa & $\$ 2.70$ & $0.10 \%$ & Oregon & $\$ 1.37$ & $0.06 \%$ \\
\hline Idaho & $\$ 3.52$ & $0.13 \%$ & Pennsylvania & $-\$ 0.10$ & $-0.004 \%$ \\
\hline Illinois & $-\$ 0.63$ & $-0.02 \%$ & Rhode Island & $-\$ 0.44$ & $-0.01 \%$ \\
\hline Indiana & $\$ 3.07$ & $0.13 \%$ & South Carolina & $-\$ 0.97$ & $-0.04 \%$ \\
\hline Kansas & $\$ 1.02$ & $0.04 \%$ & South Dakota & $\$ 0.36$ & $0.02 \%$ \\
\hline Kentucky & $\$ 5.69$ & $0.21 \%$ & Tennessee & $-\$ 0.93$ & $-0.05 \%$ \\
\hline Louisiana & $-\$ 3.33$ & $-0.14 \%$ & Texas & $\$ 1.87$ & $0.04 \%$ \\
\hline Massachusetts & $\$ 2.20$ & $0.06 \%$ & Utah & $\$ 1.03$ & $0.07 \%$ \\
\hline Maryland & $\$ 4.40$ & $0.17 \%$ & Virginia & $\$ 0.60$ & $0.03 \%$ \\
\hline Maine & $\$ 2.35$ & $0.08 \%$ & Vermont & $\$ 0.004$ & $0.02 \%$ \\
\hline Michigan & $\$ 2.62$ & $0.09 \%$ & Washington & $-\$ 2.74$ & $-0.07 \%$ \\
\hline Minnesota & $\$ 3.61$ & $0.11 \%$ & Wisconsin & $\$ 4.91$ & $0.17 \%$ \\
\hline Missouri & $\$ 3.77$ & $0.17 \%$ & West Virginia & $\$ 2.58$ & $0.09 \%$ \\
\hline Mississippi & $\$ 2.26$ & $0.08 \%$ & Wyoming & $\$ 6.75$ & $0.17 \%$ \\
\hline
\end{tabular}

Notes: All figures reported are in 1992 dollars (CPI).

Source: Statistical Abstract of the United States and phone survey of states. 
Table 2.1 also reports each state's average total current savings as a percentage of the state's 1996 general fund revenue. As a percentage of revenue, Alaska's average current savings is the largest at 0.66 percent of revenue. However, the average current savings of Delaware, Kentucky, and North Dakota were the next largest as a percentage of the state's 1996 revenue. Most states average current savings were roughly one-tenth of one percent of the state's 1996 general fund revenue.

While ten states have averaged dissaving over the post-war period on an annual basis, this dissaving does not indicate that these states are less prepared for periods of fiscal stress relative to states which averaged positive savings on an annual basis over the same period. Since states' abilities to solve periods of fiscal stress depends on the total quantity of funds available, the states in Table 2.1 which have averaged dissaving from 1945 to 1996 have simply averaged reducing their total balances each year during this time. Table 2.2, which illustrates each state's average per capita total balances over the post-war period, makes this point even more clear. From Table 2.2 one can see that Alabama has maintained average total per capita balances of $\$ 12.38$, yet the state has also averaged dissaving annually over the same period. This implies that while Alabama has funds available to deal with an economic downturn, the state's per capita reserve balances have been declining, on average, during the post-war period.

In addition, several states have averaged negative total balances while averaging positive current contributions to total balances. For instance, Hawaii has averaged the largest total balance deficit while also averaging positive current savings. Hawaii's total balance deficit has averaged $-\$ 38.25$ per person while averaging annual gains to total 
balances of $\$ 1.93$ per person. Thus, while Hawaii's total balances has averaged a deficit, the state has averaged annually increasing their total balances in the post-war era (or reducing their total balance deficit).

Moreover, Table 2.2 illustrates that 9 states have averaged negative total balances over the period from 1945 to 1996 . Of these 9 states, only New Hampshire, Rhode Island, and Washington have also averaged annual dissaving during the post-war period. Hence

Table 2.2 - States' Average Total Balances Behavior 1945-1996

\begin{tabular}{|c|c|c|c|c|c|}
\hline State & $\begin{array}{c}\text { Average } \\
\text { Per Capita } \\
\text { Total } \\
\text { Balances } \\
\end{array}$ & $\begin{array}{c}\text { Average Total } \\
\text { Balances as a } \\
\% \text { of } 1996 \\
\text { Revenue } \\
\end{array}$ & State & $\begin{array}{c}\text { Average } \\
\text { Per Capita } \\
\text { Total } \\
\text { Balances } \\
\end{array}$ & $\begin{array}{c}\text { Average Total } \\
\text { Balances as a } \\
\% \text { of } 1996 \\
\text { Revenue } \\
\end{array}$ \\
\hline Alaska & $\$ 1266.87$ & $12.53 \%$ & Montana & $\$ 42.57$ & $1.38 \%$ \\
\hline Alabama & $\$ 12.38$ & $0.55 \%$ & North Carolina & $\$ 22.64$ & $0.75 \%$ \\
\hline Arkansas & $\$ 43.34$ & $1.50 \%$ & North Dakota & $\$ 64.87$ & $2.16 \%$ \\
\hline Arizona & $\$ 12.46$ & $0.19 \%$ & Nebraska & $\$ 38.17$ & $1.44 \%$ \\
\hline California & $\$ 19.15$ & $0.32 \%$ & New Hampshire & $-\$ 65.87$ & $-2.05 \%$ \\
\hline Colorado & $\$ 47.94$ & $1.70 \%$ & New Jersey & $\$ 14.07$ & $0.48 \%$ \\
\hline Connecticut & $\$ 19.23$ & $0.73 \%$ & New Mexico & $\$ 187.29$ & $4.14 \%$ \\
\hline Delaware & $\$ 86.41$ & $2.36 \%$ & Nevada & $\$ 36.24$ & $0.55 \%$ \\
\hline Florida & $\$ 11.45$ & $0.19 \%$ & New York & $\$ 54.38$ & $1.47 \%$ \\
\hline Georgia & $\$ 17.72$ & $0.52 \%$ & Ohio & $-\$ 3.53$ & $-0.16 \%$ \\
\hline Hawaii & $-\$ 38.25$ & $-0.44 \%$ & Oklahoma & $\$ 56.77$ & $2.44 \%$ \\
\hline Iowa & $-\$ 24.85$ & $-0.97 \%$ & Oregon & $\$ 6.65$ & $0.39 \%$ \\
\hline Idaho & $\$ 42.91$ & $1.41 \%$ & Pennsylvania & $\$ 1.02$ & $0.07 \%$ \\
\hline Illinois & $\$ 10.75$ & $0.46 \%$ & Rhode Island & $-\$ 33.29$ & $-1.02 \%$ \\
\hline Indiana & $\$ 53.85$ & $2.15 \%$ & South Carolina & $\$ 19.14$ & $0.66 \%$ \\
\hline Kansas & $\$ 31.25$ & $1.20 \%$ & South Dakota & $-\$ 1.95$ & $-0.08 \%$ \\
\hline Kentucky & $\$ 11.80$ & $0.47 \%$ & Tennessee & $\$ 15.17$ & $0.54 \%$ \\
\hline Louisiana & $\$ 13.34$ & $0.40 \%$ & Texas & $\$ 71.29$ & $2.46 \%$ \\
\hline Massachusetts & $-\$ 20.61$ & $-0.50 \%$ & Utah & $\$ 7.33$ & $0.30 \%$ \\
\hline Maryland & $\$ 26.62$ & $1.19 \%$ & Virginia & $\$ 17.49$ & $0.71 \%$ \\
\hline Maine & $\$ 34.56$ & $1.22 \%$ & Vermont & $-\$ 6.83$ & $-0.04 \%$ \\
\hline Michigan & $\$ 30.16$ & $1.06 \%$ & Washington & $-\$ 19.12$ & $-0.48 \%$ \\
\hline Minnesota & $\$ 81.98$ & $2.33 \%$ & Wisconsin & $\$ 58.93$ & $1.91 \%$ \\
\hline Missouri & $\$ 34.00$ & $1.42 \%$ & West Virginia & $\$ 4.17$ & $0.12 \%$ \\
\hline Mississippi & $\$ 18.56$ & $0.74 \%$ & Wyoming & $\$ 247.72$ & $6.29 \%$ \\
\hline
\end{tabular}

Notes: All figures reported are in 1992 dollars (CPI).

Source: Statistical Abstract of the United States and phone survey of states. 
most states which have averaged total balance deficits during the post-war period have reduced their total balance deficit with their positive current savings. This dissaving in total balances while maintaining positive current savings is common for states, especially following recessions. If a state has negative total balances equaling $\$ 10$ million, or a deficit in the sum of their general fund and budget stabilization fund, at the beginning of the recovery phase and saves $\$ 1$ million during the next fiscal year, their current savings will be positive and equal to $\$ 1$ million while their total balances remain negative (and equal to $\$ 9$ million).

Of the states averaging total balance deficits, New Hampshire has averaged the largest per capita deficit, exceeding $\$ 65$ per person. Excluding Alaska, the state with the largest average per capita total balances over the post-war period has been Wyoming, with average balances of more than $\$ 247$ per person. New Mexico had the next largest average balances with more than $\$ 187$ per person, and 8 more states have averaged per capita balances of more than $\$ 50$.

While the average per capita balances of each state is an important indicator of each state's ability to survive revenue shortfalls, per capita figures at the level of an individual state make it difficult to ascertain the aggregate magnitude of states' total balances. Figure 2.2, which plots total state balances as a percentage of Gross Domestic Product, illustrates the size of total balances maintained by state governments. As a share of Gross Domestic Product, aggregate state total balances reached its peak in the mid1960s when the stock of savings was roughly 0.7 percent. During the post-war era, aggregate total balances has averaged around 0.3 percent of Gross Domestic Product. 
Aside from large increases in aggregate total balances during the mid-1960s and mid1970s, which subsequently vanished during the next recession, the decade of the 1980s witnessed large aggregate total balances as a percentage of GDP. Throughout the entire decade of the 1980s, aggregate total balances did not fall below 0.2 percent of Gross Domestic Product. In fact, the average annual growth rate in aggregate total balances throughout the 1980 s exceeded 16 percent.

In addition, apart from the aggregate negative total balances which occurred during the 1990-1991 recession, the 1990s seemed poised to be the second decade in a row in which aggregate total balances fair well. Even including the recession years of the

Figure 2.2 - Aggregate Total Balances as a Percentage of GDP 1950-1996

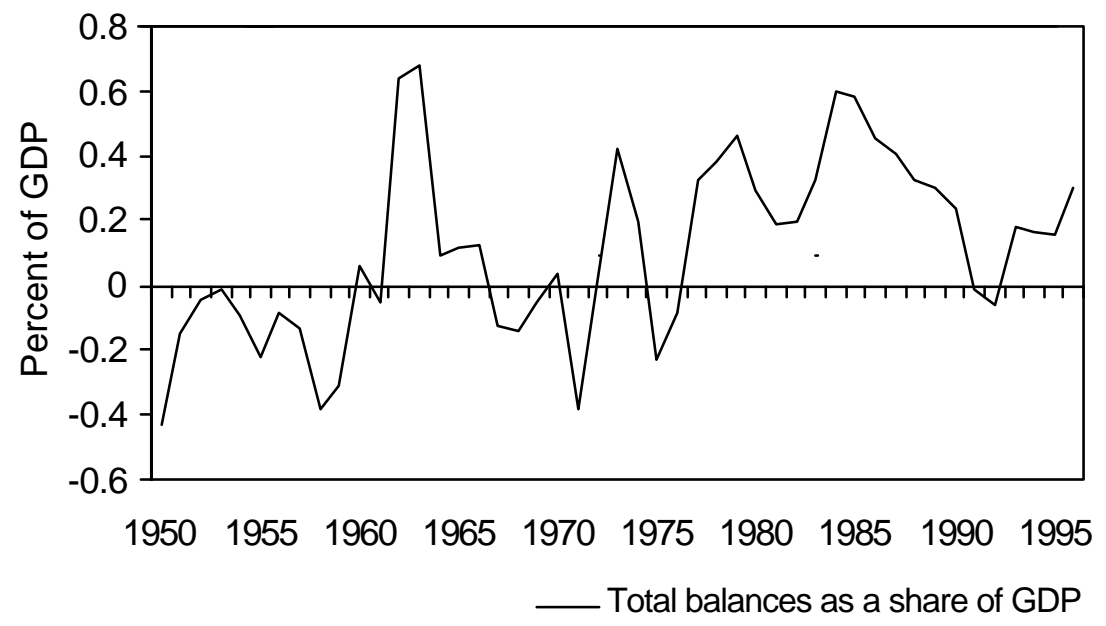

early 1990s, the average growth rate in aggregate total balances from 1990 to 1996 exceeded 83 percent. Between fiscal years 1992 and 1993 aggregate total balances increased more than $\$ 16$ billion, translating into an annual growth rate of more than 490 percent! 
One factor that may have played a role in the large increases in states' total balances over the past two decades is budget stabilization funds. As alluded to in the introduction, most states now utilize stabilization funds in addition to the state's general fund for retaining fungible reserves. Although New York was the first state to begin utilizing a budget stabilization fund in 1945, the vast majority of states did not begin utilizing budget stabilization funds until after 1980 (only ten states utilized budget stabilization funds prior to 1980). While Chapters 4 and 5 address particular questions regarding budget stabilization funds and states' savings behavior, it is useful to provide a general overview of budget stabilization fund usage.

As Figure 2.3 illustrates, aggregate budget stabilization fund balances represent a sizable component of states' total balances, although general fund surpluses continue to account for the majority of total balances. Aggregate stabilization fund balances peaked in 1979 at nearly $\$ 10$ billion before falling to into deficit during the 1980-1982 recession. In recent years, aggregate budget stabilization fund balances have been increasing, reaching more than $\$ 8$ billion dollars by the end of fiscal year 1996.

While budget stabilization funds represent a respectable share of states' total balances, there is no guarantee that the dramatic increase in budget stabilization fund usage has caused the increase in states' total balances over the last two decades. Since budget stabilization balances for most states are deposited from the state's general fund surplus, budget stabilization funds and states' general funds may be fungible substitutes. That is, states' fiscal positions may not be enhanced when the state retains balances in the general fund and a stabilization fund since those balances could have otherwise been 
Figure 2.3 - Aggregate Total Balances and Aggregate Total Budget Stabilization Fund Balances 1945-1996

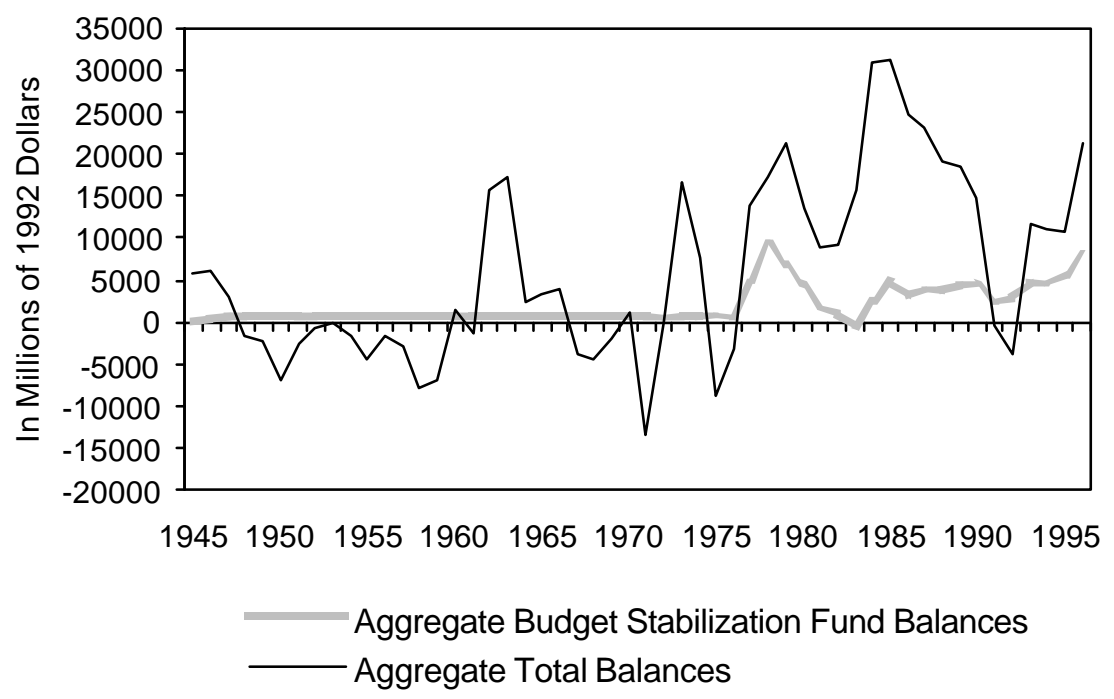

retained in the state's general fund.

The year each state began utilizing budget stabilization funds and each state's average total balances retained in stabilization funds during the 1990s is presented in Table 2.3. As is evident, states' reliance on budget stabilization funds varies, but most states have retained positive average total balances during the 1990s. The only state which has averaged a stabilization fund deficit is California, averaging a deficit of more than $\$ 50$ million. Although it may seem odd that states can run deficits in their stabilization funds, most states' statutes do not prohibit deficits. Since stabilization funds are separate accounts in the state's budget, just like capital accounts for instance, California (as well as other states) is permitted to run a deficit in their stabilization fund by issuing bonds. ${ }^{9}$

\footnotetext{
${ }^{9}$ See California's Government Code Section 16312 and Section 16314.
} 
Table 2.3 - Summary of States' Budget Stabilization Fund Usage (in millions of 1992 dollars)

\begin{tabular}{|c|c|c|c|c|c|c|c|}
\hline State & $\begin{array}{c}\text { Year of } \\
\text { First BSF } \\
\text { Adoption }\end{array}$ & $\begin{array}{c}\text { Total } \\
\text { Balances - } \\
\text { Average of } \\
\text { 1990s }\end{array}$ & $\begin{array}{c}\text { Total } \\
\text { Balances in } \\
\text { BSF - } \\
\text { Average of } \\
\text { 1990s } \\
\end{array}$ & State & $\begin{array}{c}\text { Year of } \\
\text { First BSF } \\
\text { Adoption }\end{array}$ & $\begin{array}{c}\text { Total } \\
\text { Balances - } \\
\text { Average of } \\
\text { 1990s }\end{array}$ & $\begin{array}{c}\text { Total } \\
\text { Balances in } \\
\text { BSF - } \\
\text { Average of } \\
\text { 1990s }\end{array}$ \\
\hline AK & 1986 & $\$ 1294.56$ & $\$ 259.16$ & MT & -- & $\$ 61.52$ & -- \\
\hline $\mathrm{AL}$ & -- & $\$ 125.89$ & -- & $\mathrm{NC}$ & 1991 & $\$ 411.36$ & $\$ 161.61$ \\
\hline AR & -- & $\$ 227.77$ & -- & ND & 1987 & $\$ 105.88$ & $\$ 9.67$ \\
\hline $\mathrm{AZ}$ & 1990 & $\$ 126.80$ & $\$ 64.85$ & $\mathrm{NE}$ & 1983 & $\$ 88.15$ & $\$ 25.87$ \\
\hline $\mathrm{CA}$ & 1976 & $-\$ 2106.72$ & $-\$ 53.90$ & $\mathrm{NH}$ & 1987 & $-\$ 84.84$ & $\$ 10.67$ \\
\hline $\mathrm{CO}$ & 1983 & $\$ 591.16$ & $\$ 200.41$ & $\mathrm{NJ}$ & 1990 & $\$ 67.49$ & $\$ 99.98$ \\
\hline $\mathrm{CT}$ & 1979 & $\$ 56.97$ & $\$ 25.98$ & NM & 1966 & $\$ 238.33$ & $\$ 113.82$ \\
\hline $\mathrm{DE}$ & 1977 & $\$ 320.00$ & $\$ 69.58$ & NV & 1994 & $\$ 35.89$ & $\$ 31.44$ \\
\hline FL & 1959 & $-\$ 480.26$ & $\$ 186.58$ & NY & 1945 & $\$ 1560.67$ & $\$ 78.41$ \\
\hline GA & 1976 & $-\$ 140.86$ & $\$ 129.77$ & $\mathrm{OH}$ & 1981 & $\$ 18.69$ & $\$ 245.81$ \\
\hline $\mathrm{HI}$ & -- & $-\$ 56.01$ & -- & $\mathrm{OK}$ & 1985 & $\$ 311.27$ & $\$ 110.95$ \\
\hline IA & 1984 & $\$ 55.03$ & $\$ 63.56$ & OR & -- & $\$ 253.04$ & -- \\
\hline ID & 1984 & $\$ 215.10$ & $\$ 31.01$ & $\mathrm{PA}$ & 1985 & $-\$ 186.98$ & $\$ 56.71$ \\
\hline IL & -- & $\$ 158.70$ & -- & RI & 1985 & $\$ 184.00$ & $\$ 27.62$ \\
\hline IN & 1982 & $\$ 756.41$ & $\$ 345.82$ & $\mathrm{SC}$ & 1978 & $-\$ 108.06$ & $\$ 136.89$ \\
\hline $\mathrm{KS}$ & 1993 & $\$ 158.95$ & $\$ 18.14$ & SD & 1991 & $\$ 32.09$ & $\$ 12.46$ \\
\hline KY & 1983 & $\$ 515.67$ & $\$ 61.44$ & $\mathrm{TN}$ & 1972 & $-\$ 173.48$ & $\$ 88.05$ \\
\hline LA & 1990 & $-\$ 253.01$ & $\$ 0$ & TX & 1987 & $\$ 1047.48$ & $\$ 39.57$ \\
\hline MA & 1986 & $\$ 110.79$ & $\$ 261.67$ & UT & 1986 & $\$ 107.93$ & $\$ 52.51$ \\
\hline MD & 1986 & $\$ 725.88$ & $\$ 143.73$ & VA & 1992 & $\$ 332.19$ & $\$ 21.37$ \\
\hline $\mathrm{ME}$ & 1985 & $\$ 34.99$ & $\$ 6.39$ & VT & 1988 & $\$ 3.58$ & $\$ 3.21$ \\
\hline MI & 1977 & $\$ 981.95$ & $\$ 512.32$ & WA & 1981 & $-\$ 400.11$ & $\$ 162.52$ \\
\hline $\mathrm{MN}$ & 1981 & $\$ 726.17$ & $\$ 456.57$ & WI & 1981 & $\$ 785.50$ & $\$ 254.40$ \\
\hline MO & 1992 & $\$ 630.22$ & $\$ 17.70$ & WV & 1994 & $\$ 197.95$ & $\$ 9.69$ \\
\hline $\mathrm{MS}$ & 1982 & $\$ 365.92$ & $\$ 95.28$ & WY & 1982 & $\$ 158.08$ & $\$ 19.92$ \\
\hline
\end{tabular}

Notes: Many states have multiple budget stabilization funds so the date of adoption presented is the year in which each state began utilizing their first stabilization fund. See Chapters 4 and 5 for a more thorough discussion of stabilization funds. The average total balances retained in stabilization funds during the 1990s include balances from all stabilization funds.

As Table 2.3 also illustrates, many states have averaged total balance deficits during the 1990s while maintaining positive average stabilization fund balances. This simply implies that states such as Florida, Georgia, Pennsylvania, South Carolina, 
Tennessee, and Washington, have averaged general fund deficits large enough to more than offset their average positive stabilization fund balances.

In addition to states who have averaged general fund deficits, many other states have averaged stabilization fund balances during the 1990s that are in excess of the state's average general fund position. This, at least on the surface, suggests that states consider the use of stabilization funds as an important vehicle for mitigating periods of fiscal stress.

\subsection{Budget Stabilization Fund Data}

While nearly all of the data presented in this chapter and used throughout the dissertation are from common sources, such as the Statistical Abstract of the United States, this dissertation utilizes a new data set on state budget stabilization fund balances and date of fund adoption which has been previously unavailable to the literature.

All previous studies investigating the savings behavior of state governments, namely Sobel and Holcombe (1996a) and Knight and Levinson (1999a), have relied upon data published by the National Association of State Budget Officers (NASBO). Since 1983 the NASBO has published the fiscal-year-end balance of each state's budget stabilization fund(s). However, these studies have been limited because fiscal-year-end balances were not reported separately from the state's general fund balance prior to 1983 .

The data set used in this dissertation was obtained by contacting each states by phone to obtain the fiscal-year-end balances of the state's budget stabilization fund(s) over the state's entire history of budget stabilization fund usage, date(s) of budget stabilization fund(s) adoption, and information regarding the rules governing the use of 
stabilization fund monies. ${ }^{10}$ The data obtained from each state does not match the fiscalyear-end balances reported by the NASBO very well. Table 2.4 illustrates the difference between the fiscal-year-end balances used in the dissertation that were obtained from each state and the fiscal-year-end balances reported by the NASBO.

As is evident from Table 2.4, there are several noticeable, and some quite sizable, differences between the fiscal-year-end balances reported by individual states and the balances reported by the NASBO. Of the 44 states having budget stabilization funds, the difference between the fiscal-year-end balance reported by individual states and the balance reported by the NASBO differ by an absolute value of more than $\$ 100$ million for 8 states, with Alaska's differing by more than $\$ 1$ billion. The average absolute value difference for fiscal year 1994 alone is more than $\$ 77$ million dollars. In the aggregate, the figures reported by each state are $\$ 1.2$ billion more than the aggregate figures reported by the NASBO.

The data obtained from each state possess several advantages over any published data on the fiscal-year-end balances of budget stabilization funds. First, the data provided by the states is likely to be more accurate than the data published by a second-hand source. Second, I obtained the year in which each state's budget stabilization fund was adopted, which was data not published by NASBO. Third, obtaining each state's

\footnotetext{
${ }^{10} \mathrm{I}$ am indebted to the following individuals for their assistance in obtaining these data: Carolyn Middleton, Rick Zelznak, Robert Waisbord, Margaret Feigee, Alan Boifsvert, Bob Harris, David Blowman, Linda Keillor, Bill Smith, Rose Renn, Mark Brown, Calvin McKelvogue, Ron Carson, Steve Winham, Keith Todd, Neil Bergsman, Tim Sullivan, Nancy Rooney, Beth Colosimo, Tom Kynerd, Mark Reading, Gerry Oligmueller, Tom Martin, Nancy Jones, Michael Benze, John Traylor, Emily Sams, Jim Belonus, Frank Rainwater, Bill Anderson, Shawn Ashley, Bill Petersen, Jason Dilges, Bryan Chriske, Lisa Minton, Patrick Ogden, Sheila Rogers, Pam Davidson, John Montgomery, Lori Peal, and Jeff Urry.
} 
fiscal-year-end balance over the state's entire history of stabilization fund usage provides more flexibility to examine the role of stabilization funds in influencing states' fiscal health than had previously been permitted.

Table 2.4 - Comparison of NASBO Reported Balances and Data Obtained from Each State: Fiscal Year 1994 (in millions of nominal dollars)

\begin{tabular}{|c|c|c|c|c|c|}
\hline State & $\begin{array}{c}\text { NASBO } \\
\text { Reported } \\
\text { Balance } \\
\end{array}$ & $\begin{array}{c}\text { State Reported } \\
\text { Balance }\end{array}$ & State & $\begin{array}{c}\text { NASBO } \\
\text { Reported } \\
\text { Balance } \\
\end{array}$ & $\begin{array}{l}\text { State Reported } \\
\text { Balance }\end{array}$ \\
\hline$\overline{\mathrm{AK}}$ & $\$ 1014.5$ & $\$ 2.03$ & MT & -- & -- \\
\hline $\mathrm{AL}$ & -- & -- & $\mathrm{NC}$ & $\$ 175.9$ & $\$ 210.6$ \\
\hline AR & -- & -- & ND & $\$ 0$ & $\$ 0$ \\
\hline $\mathrm{AZ}$ & $\$ 33.5$ & $\$ 42.2$ & $\mathrm{NE}$ & $\$ 24.7$ & $\$ 27.8$ \\
\hline $\mathrm{CA}$ & $-\$ 410$ & $-\$ 362.2$ & $\mathrm{NH}$ & $\$ 20$ & $\$ 20$ \\
\hline $\mathrm{CO}$ & $\$ 134.4$ & $\$ 310$ & NJ & $\$ 155.5$ & $\$ 158.9$ \\
\hline $\mathrm{CT}$ & $\$ 0$ & $\$ 0$ & NM & $\$ 94.2$ & $\$ 156.1$ \\
\hline $\mathrm{DE}$ & $\$ 71.7$ & $\$ 71.7$ & NV & $\$ 0$ & $\$ 19$ \\
\hline FL & $\$ 296.6$ & $\$ 296.2$ & NY & $\$ 134$ & $\$ 134.2$ \\
\hline GA & $\$ 0$ & $\$ 267.2$ & $\mathrm{OH}$ & $\$ 21$ & $\$ 21$ \\
\hline HI & -- & -- & OK & $\$ 91.1$ & $\$ 45.6$ \\
\hline IA & $\$ 34.4$ & $\$ 38.4$ & OR & -- & -- \\
\hline ID & $\$ 18.4$ & $\$ 32.9$ & PA & $\$ 25$ & $\$ 29.8$ \\
\hline IL & -- & -- & RI & $\$ 41.9$ & $\$ 43$ \\
\hline IN & $\$ 205$ & $\$ 370.3$ & $\mathrm{SC}$ & $\$ 66.5$ & $\$ 167$ \\
\hline $\mathrm{KS}$ & $\$ 75$ & $\$ 78$ & SD & $\$ 24.9$ & $\$ 21.6$ \\
\hline KY & $\$ 33.5$ & $\$ 90$ & $\mathrm{TN}$ & $\$ 100$ & $\$ 101.4$ \\
\hline LA & $\$ 0$ & $\$ 0$ & $\mathrm{TX}$ & $\$ 0$ & $\$ 29.1$ \\
\hline MA & $\$ 230.4$ & $\$ 383$ & UT & $\$ 64.3$ & $\$ 41.6$ \\
\hline MD & $\$ 152.6$ & $\$ 161.8$ & VA & $\$ 31.1$ & $\$ 0$ \\
\hline $\mathrm{ME}$ & $\$ 0$ & $\$ 0$ & VT & $\$ 0$ & $\$ 1$ \\
\hline MI & $\$ 61$ & $\$ 775.5$ & WA & $\$ 125$ & $\$ 125$ \\
\hline $\mathrm{MN}$ & $\$ 360$ & $\$ 500$ & WI & $\$ 0$ & $\$ 234.9$ \\
\hline MO & $\$ 20.1$ & $\$ 36.9$ & WV & $\$ 0$ & $\$ 0$ \\
\hline MS & $\$ 160$ & $\$ 162.9$ & WY & $\$ 0$ & $\$ 19.3$ \\
\hline
\end{tabular}

Notes: States for which no figures are reported do not have budget stabilization funds.

Source for the NASBO figures: Fiscal Survey of States, NASBO.

\subsection{Conclusion}

The data presented in this chapter have illustrated the magnitude and recent trends in the

post-war savings behavior of state governments. As the data indicate, most states have 
been active savers in the sense that they have averaged positive current savings over the post-war period. Thus a majority of states have been adding to their total balances over this period, which implies that most states have been enhancing their fiscal positions through saving.

Moreover, the additions to states' total balances have been quite profound in recent decades. Aside from the 1990-1991 recession, aggregate total balances retained by states during the 1980s and 1990s has averaged more than 0.5 percent of Gross Domestic Product. The fact that more than 30 of the 44 states utilizing budget stabilization funds did not adopt their stabilization fund until after 1980 is suggestive that budget stabilization funds have contributed to the savings gains experienced by states in recent years. 


\section{Chapter 3}

\section{Political Control and Public Sector Savings: Life Cycle Evidence from the States}

\subsection{Introduction}

The institutional structure of the public sector essentially affords individual and group decision-makers within government an opportunity to exert disproportionate control over political outcomes. Two ways that individuals and/or groups may control political outcomes is through centralized vote-trading (or block-voting) and agenda control. As McKelvey (1976) first noted, under majority rule any individual that can control pairwise votes in the agenda may obtain any outcome they desire. Since members of the majority party of a legislature control legislative leadership positions, such as committee chair and speaker positions, and thus determine which legislation receives hearings and votes, these individuals (or group if they are acting on the party's behalf) may exert tremendous influence over the political agenda. Experiments by Plott and Levine (1978) illustrated that such agenda control can have a dramatic affect on voting outcomes. Thus members (and leaders of the majority party) can exert tremendous influence on political outcome through their ability to manipulate the agenda.

Second, the majority party can essentially dictate the outcome of any majority rule vote since their numbers are superior. In order to determine the political outcome, the members of the majority must of course all vote in a similar manner. Koford (1982) developed a model in which such block-voting was optimal for parties. In his model, party leaders were responsible for organizing vote-trading among party members in an effort to maximize the party's welfare. In essence, party leaders maximized their party's welfare by organizing the party to vote in a similar manner on legislation which was 
important to party leaders. As a result, any such legislation could be adopted by organizing the votes of the party members. Hence when individual legislators or parties collude on their choice of votes, it provides the group with superior membership the ability to pass or defeat any legislation they desire.

A characteristic feature of public sector savings may cause current savings to be very responsive to future political outcome control. Consider a private sector agent determining her optimal spending/saving decision. For this agent, her saving is under her explicit control. If she decides to save at time $t$ in order to spend the savings at time $t+k$ $(k>0)$, then the funds saved at time $t$ are guaranteed to be available to her in the future assuming she saves the funds in some risk-free instrument. In the public sector, this guarantee does not necessarily hold. Under a multi-party political system governed by majority rule, the right to access (and ultimately spend) public sector savings is determined by the group or party which can control the political outcome. As a result, there is no certainty beyond the previous election that the party currently controlling a state's savings will continue to control the funds in the future. In short, unlike savings of private sector individuals, public sector savings is a common pool governed by an uncertain controlling party. As a result of the known differences between the spending preferences of political parties, if political party A expects to lose control over political outcomes in the future to political party B, party A would be unlikely to save in the current period for fear that the funds will be allocated by party B in a manner not consistent with the preferences of party A. ${ }^{11}$

\footnotetext{
${ }^{11}$ For recent evidence that the composition of state-level spending differs by controlling political parties, see Husted and Kenny (1997) and Gilligan and Matsusaka (1995).
} 
In this chapter I develop a simple extension of the Life Cycle/Permanent Income model (hereafter LCPI) which can be used to formalize the effect that uncertain future political control has on an individual legislator's preferences for spending and saving. The representative legislator is assumed to maximize the present value of his utility over his infinite lifetime by choosing the level of government expenditures, subject to the state's resource constraints, to maximize the net benefits of government spending in his district. The legislator is assumed to face uncertainty regarding his reelection and his future prospects of being a member of the majority party (affording him the ability to control political outcomes). Unlike the standard private sector agent LCPI models in which agents' optimal choice of consumption is based solely on initial wealth and permanent income, the model presented here has the feature that the level of spending arising from the legislator's optimal choice is influenced not only by fiscal variables such as revenue, interest rates, and fungible assets, but also by his expected future political environment. The model implies that as a legislator's compound probability of being reelected and part of the majority party in the future diminishes, he will opt to forgo current saving in favor of current spending while he is ensured control over allocation decisions. Thus, the model implies that legislators face a trade-off in their expenditure/saving decision between the desire to smooth the net benefits of government spending to their district and the desire to spend the funds while control is certain.

To test empirically the theoretical implications of the model, I estimate a two-way fixed effects model for 39 states over the period from 1973 to 1995 . Employing binary variables of changes in the future controlling party in each legislative house to capture the effect of changes in future political outcome control and the weighted average of turnover 
rates in the state's legislature to capture the expected probability of reelection, the estimation results provide evidence that an actual change in the state's majority party in the lower house adversely affects states' current savings in the year prior to the change. In fact, the results indicate that a future change in the controlling party of a state's lower house reduces current real per capita savings by an average of 68 dollars. F-tests for the joint significance of political party changes in both the lower and upper house of a state's legislature reveal that future political outcome control is a significant determinant of the current level of savings. The results suggest that state fiscal behavior may be systematically affected by changes in the state's political environment if the change is expected, implying that politically unstable states may be ill-prepared for future recessions relative to politically stable states, other factors remaining constant.

The remainder of the chapter proceeds in the following manner. Section 3.2 briefly discusses states' use of savings as a fiscal tool and previous research examining state fiscal behavior. Section 3.3 develops the theoretical model that can be used to examine the impact that political reelection and the prospects for political control have on an individual legislator's preferences for current spending/saving and serves as the foundation for the empirical estimation. Section 3.4 chronicles the transition from theory to measurement, while Section 3.5 presents the estimation results. Section 3.6 concludes the chapter.

\subsection{Previous Investigations of State Fiscal Behavior}

Previous investigations of state fiscal behavior have focused almost exclusively on expenditures and no previous research has addressed the common pool problem inherent 
in public sector saving. Most of the previous research examining public sector spending has been based on Down's (1957) median voter model. ${ }^{12}$ In general, these models have attempted to explain public sector fiscal behavior as a function of variables reflecting preferences of the pivotal constituent. However, research by Morton (1991), Greene and Nelson (1994), and Poole and Rosenthal (1996) suggests that the behavior of legislators can not be accurately proxied using the preferences of a representative consumer. Morton (1991) claims that inefficiencies in the decision-making process of the public sector, such as cost asymmetries across voters and barriers to political competition, drive these differences between constituent and legislator preferences. In addition, Poole and Rosenthal (1996), using data for the United States Senate, reject the notion that legislators are agents for constituents even when controlling for vote-trading and reelection considerations.

In contrast to the static median voter models, recent work by Holtz-Eakin et al. (1994) and Dahlberg and Lindstrom (1998) utilized a Life Cycle/Permanent Income (LCPI) framework for studying state and local government expenditures which forms the basis for the model developed in Section 3.3. One of the key features of the LCPI framework is that agents are forward looking. They make choices based on information that often extends well beyond one period. In the LCPI models of Holtz-Eakin et al. (1994) and Dahlberg and Lindstrom (1998), they examine public sector spending assuming a representative private sector agent (or bureaucrat) to determine the share of

\footnotetext{
${ }^{12}$ For some of the initial models utilizing the median voter theory see Barr and Davis (1966), Davis and Hines (1966), and Bergstrom and Goodman (1973). For recent applications of the median voter model see Holcombe (1980), Gramlich and Rubinfeld (1982), Holcombe (1989), and Turnbull and Mitias (1995).
} 
aggregate state and local spending that is explained by permanent as opposed to current resources. Their models, while similar in theory but differing in data aggregation, provide an interesting contrast of results. Holtz-Eakin et al. (1994), examining aggregate state and local expenditures in the U.S., find that nearly 100 percent of state and local expenditures are determined by current rather than permanent resources. Dahlberg and Lindstrom (1998) on the other hand, find that most (around 90 percent) of local expenditures in Sweden are determined by permanent rather than current resources.

While the general intertemporal framework utilized by previous researchers is insightful for examining public sector decisions, their choice to model a private sector agent (or bureaucrat) ignores central differences between the private and public sector. In the public sector, decisions are not made solely by one individual, rather they are determined by a collection of individual legislators. As alluded to earlier, research suggests that differences between the preferences of legislators and the preferences of constituents may be substantial. Ignoring the institutional differences between the private and public sector may induce a source of bias into the theory presented. For instance, if public sector decisions were made by a benevolent social planner that always acts as his constituents desire and was not subject to removal from office, implying that they faced no uncertainty about their prospects for future control of political outcomes, then the public sector's decision-making problem would be perfectly analogous to the consumer's problem. However, this is not the case. Legislators face uncertainty regarding their political survival and their prospects for future control of political outcomes. Thus, the model developed in Section 3.3 focuses on the choices and constraints facing an individual legislator rather than a representative consumer. 


\subsection{Theoretical Treatment}

\subsubsection{The model}

The model developed here assumes a representative legislator that maximizes the present value of his lifetime utility, $V$, by choosing the level of government expenditures in each period subject to the state's resource constraint. Although the legislator must vote on the total size of the budget, his political survival is determined by the individuals (voters) within his district. So as long as the legislator continues to seek reelection, and thus requires votes from his district, he faces a powerful incentive to cater to his constituency. As a result, I assume that the legislator derives no utility from the level of government expenditures per se, rather he derives utility only from the government expenditures in his district in excess of revenue obtained from his district, which I refer to as the net benefits of spending. Hence in an effort to maximize his utility, the legislator attempts to maximize the net benefits of government expenditures in his district in any given period by choosing the total size of the budget.

The net benefits (or net spending) to the district is defined as the difference between government expenditures in the district and revenue obtained from the district. Thus, we may write the net benefits to district $i$ at time $t$ as $N B_{t}^{i}=G_{t}^{i}-R_{t}^{i}$, where $G_{t}^{i}$ and $R_{t}^{i}$ are government expenditures to district $i$ at time $t$ and revenues obtained from district $i$ at time $t$ respectively.

Defining $\theta_{t}^{i}$ and $\gamma_{t}^{i}$ as the share of total government expenditures and total revenue share corresponding to district $i$, we may write the net benefits to district $i$ as $N B_{t}^{i}=\theta_{t}^{i} G_{t}-\gamma_{t}^{i} R_{t}$, where $G_{t}$ and $R_{t}$ are the total amounts of government expenditures and revenue at time $t$. Both $\theta_{t}^{i}$ and $\gamma_{t}^{i}$ are assumed to depend on an indicator function, 
denoted $I_{t}$, which reflects one of two possible outcomes for the legislator. The first outcome, in which the indicator function equals one, is a situation in which the legislator is reelected and part of the majority party. This outcome is the scenario under which the legislator has the ability to control the political outcome. The ability to control political outcomes will have a substantial impact on his ability to direct government expenditures toward his district while simultaneously diverting taxes. However, since legislators systematically face uncertainty regarding reelection, the outcome in which a legislator is reelected and part of the majority party is not certain. Thus, we shall assume that the indicator function equals one with probability $P_{t}$, where $P_{t}$ is the legislator's exogenous compound probability of being reelected and part of the majority party.

The second outcome, under which the indicator function equals zero, is a situation in which the legislator is either not reelected or not part of the majority party. Under this scenario, the legislator is assumed to lose his ability to control the political outcome. The probability that such an event is realized is of course $1-P_{t}$. From the perspective of the legislator, the desirable outcome occurs when he is reelected and part of the majority party. This ensures that he will have greater control over the allocation of spending and taxes. Thus, over his infinite lifetime, a representative legislator should care about his prospects for controlling the political outcome in every period since the realization of such an event (which is represented by the indicator function) governs his ability to direct expenditures and redirect taxes. If the legislator is presently a member of the majority party and the majority party always votes as a uniform coalition, then the individual legislator will have the ability to control the outcome over members of the minority party. 
In addition, it is assumed that the legislator's district's share of total expenditures and total revenue, the legislator's compound probability of being in office and a member of the majority party, and the state's revenue are all known in period $t$ prior to the legislator's choice of expenditures in period $t$. Revenue obtained by the state is assumed to be exogenous and deterministic, which precludes the legislator from a precautionary motive for saving.

Using the definitions of net benefits described above and omitting the superscript $i$, the legislator's lifetime utility function, $V$, may be written as:

$$
V=\underset{\left\{G_{t}\right\}_{s=0}^{\infty}}{M A X} E_{0}\left\{\sum_{s=0}^{\infty}\left[\beta^{s} U\left[\theta\left(I_{s}\right) G_{s}-\gamma\left(I_{s}\right) R_{s}\right] \prod_{t=0}^{s} I_{t}\right]\right\}
$$

where $E_{0}$ is the legislator's expectation of future events conditional on information available at time $0, U$ is the legislator's time-separable utility function which is assumed to be concave in its function argument for all $t$ and twice continuously differentiable, and $\beta=(1 / 1+\rho)$ is the legislator's discount factor (with discount rate $\rho$ ) which is assumed to be positive and constant over time. Substituting the probability that a legislator is reelected and part of the majority party for the indicator function in equation (3.1) and setting $P_{0}=1$, allows us to write the legislator's maximization as:

$$
V=\begin{gathered}
M A X \\
\left\{G_{t}\right\}_{s=0}^{\infty}
\end{gathered} \quad \sum_{s=0}^{\infty}\left\{\beta^{s} U\left[\theta_{s} G_{s}-\gamma_{s} R_{s}\right] \prod_{t=0}^{s} P_{t}\right\}
$$

subject to

$$
A_{t+1}=\left(1+r_{t}\right) A_{t}+R_{t}-G_{t}
$$


where $A_{t}$ denotes the state's stock of fungible assets available at time $t$, and $r_{t}$ is the real rate of interest at which the state can lend and borrow freely which is assumed to be exogenous. $^{13}$

The choice to model the state's resource constraint as permanent rather than current resources coincides with the Holtz-Eakin et al. (1994) and Dahlberg and Lindstrom (1998) framework. Both Inman (1983) and Holtz-Eakin (1994) have argued that actual spending of state governments does not have to coincide with planned expenditures outlined in the state's budget. In fact, of the 49 states currently utilizing some form of a balanced budget rule, only 17 states have constitutional requirements that the Governor submit and sign, and the legislature adopt, a balanced budget. In a majority of states, legislators (and the Governor) are merely required to adopt a balanced budget projection no matter how unrealistic it may be. ${ }^{14}$

The model can be thought of almost as a general case of a standard consumer LCPI model. If the representative legislator were replaced by a single social planner or a

13 To simplify the model, we do not distinguish between not being reelected and not being a member of the majority party. In either situation, which occurs with probability $1-P_{t}$, the model implies that the legislator will receive no utility because the future becomes irrelevant for the legislator. If a legislator is elected to office again in the future we assume that future savings is independent of previous savings since future savings will depend on the optimization facing future legislators. In addition, this simplification ignores any utility premium for holding public office over the private sector. Sobel (1992) developed a model in which such a utility premium was crucial to a legislator's endogenous choice to remain in office. In his model, a legislator could optimally shirk himself out of office if his choice in office increased his expected utility in the private sector. The decision to ignore such a distinction greatly simplifies the derivation of the model without altering the qualitative results.

${ }^{14}$ For specific information regarding state balanced budget rules, see Budget Processes in the States, September 1997, National Association of State Budget Officers. Moreover, Holtz-Eakin et al. (1994, p.160) cite an example in which the Governor of New Jersey submitted a budget to the legislature which had little chance of being realized. 
representative private sector agent that were not subject to issues such as reelection and political districts, then the model breaks down into the basic LCPI model in which private sector agents prefer perfect expenditure smoothing so long as private consumption and government expenditures are separable in the agent's utility function (which is the finding of Dahlberg and Lindstrom, 1998). Thus the model captures how features of public sector decision-making, such as political control and reelection, can force government expenditures to deviate from the consumer-preferred smooth path. ${ }^{15}$

To solve the model, we may apply dynamic programming methods and substitute the equation of motion, equation (3.3), into the objective function and rewrite the objective function to contain both a current and future component. Doing so allows us to rewrite the objective function as:

$$
V\left(A_{t}, X_{t}\right)=\stackrel{M A X}{G_{t}}\left\{U\left(\theta_{t} G_{t}-\gamma_{t} R_{t}\right)+\beta P_{t+1} V\left(A_{t+1}, X_{t+1}\right)\right\}
$$

where the value function, $V\left(A_{t}, X_{t}\right)$, is the maximum obtained value from the legislator's optimization. $X_{t}$ is a vector of the model's state variables at time $t$. Since $P_{t}$ is a probability which is realized at time $t$ prior to the choice of spending, it acts only as scalar in the model. As a result, the probability that a legislator is reelected and part of the

\footnotetext{
${ }^{15}$ The fact that optimal government expenditures should follow a smooth path can easily be derived for a representative private sector agent using the LCPI model. As long as the agent's rate of time preference equals the real interest rate and private sector consumption is separable from government expenditures, private sector agents would prefer a smooth expenditure path. See Dahlberg and Lindstrom (1998) for such a derivation. An interesting extension to this model would integrate the notions of expenditure smoothing, tax smoothing (see Barro, 1979) and credit markets conditions (Poterba and Rueben, 1997) into a model with an uncertain political climate. Unfortunately, such a model is beyond the scope of this chapter. An interesting note to such a model is that Strazicich (1997, 1996), using state-level data, found no evidence that states engage in tax smoothing.
} 
majority at time $t+1$ serves essentially as a state variable at time $t$. In addition, since the future component of the value function, $V\left(A_{t+1}, X_{t+1}\right)$, assumes optimal behavior in every future period, $X_{t+1}$ includes not only the state variables from time $t+1$, but also the state variables from every future period. Thus, $X_{t+1}=\left\{\left\{R_{t+k}\right\},\left\{P_{t+k+1}\right\},\left\{r_{t+k}\right\}\right\}$ for $k=1, \ldots, \infty$.

Formulating the model in this framework allows for a straightforward examination of the comparative statics, which is presented in Section 3.3.2. To obtain the first-order condition, we may differentiate equation (3.4) with respect to the choice variable which yields:

$$
\theta_{t} U_{N}\left(\theta_{t} G_{t}-\gamma_{t} R_{t}\right)=\beta P_{t+1} V_{A}\left(A_{t+1}, X_{t+1}\right)
$$

where $U_{N}$ is the derivative of the utility function with respect to the net benefits argument. While useful for comparative statics, the intuition from equation (3.5) is rather difficult given the future component of the value function. ${ }^{16}$ However, using the value function we may derive an equivalent first-order condition that can easily be interpreted. Differentiating equation (3.4) with respect to $A_{t}$ using the envelope theorem yields:

$$
V_{A}\left(A_{t}, X_{t}\right)=\beta P_{t+1}\left(1+r_{t}\right) V_{A}\left(A_{t+1}, X_{t+1}\right) .
$$

Combining equation (3.5) and (3.6) gives us:

$$
V_{A}\left(A_{t}, X_{t}\right)=\left(1+r_{t}\right) \theta_{t} U_{N}\left(\theta_{t} G_{t}-\gamma_{t} R_{t}\right)
$$

\footnotetext{
16 The transversality condition for the model requires that $\lim _{t \rightarrow \infty} \beta^{t} \prod_{s=0}^{t} P_{s} V_{A}\left(A_{t+1}^{*}, X_{t+1}\right) A_{t+1}^{*}=0$, where $A_{t+1}^{*}$ is an optimum.
} 
Substituting equation (3.7) into the left hand side of equation (3.5) and substituting the one period update of equation (3.7) into the right side of equation (3.5) yields:

$$
\theta_{t} U_{N}\left(\theta_{t} G_{t}-\gamma_{t} R_{t}\right)=\beta P_{t+1}\left(1+r_{t+1}\right) \theta_{t+1} U_{N}\left(\theta_{t+1} G_{t+1}-\gamma_{t+1} R_{t+1}\right)
$$

which is the common formulation of the first-order condition in this type of model.

Unlike the standard private sector agent LCPI model in which the evolution of government spending between periods is determined by the relative intertemporal prices, this formulation implies that the evolution of government spending between periods depends on relative prices and the legislator's expected political environment. Notice in equation (3.8) that the legislator's realized and expected compound probability of being reelected and a member of the majority party act as additional discount factors in the legislator's optimal choice of expenditures (through its effect on $\boldsymbol{\theta}_{t}$ ). If the legislator's expected probability of being reelected and part of the majority at time $t+1$ tends to zero, then this reduction serves to discount future utility. As a result, when the compound probability that he will be reelected and part of the majority falls, ceteris paribus, the legislator will opt to increase spending in the current period (while he is guaranteed to control the outcome) and forgo current saving. The incentive to save is greatly diminished when a legislator's prospects for controlling the outcome shrink because he is aware that any savings at time $t$ may not be accessible by him at time $t+1$. Thus, a utilitymaximizing legislator will choose to increase spending in the current period, thereby increasing his current utility, while he in ensured control over political outcomes if it is likely that his position will change in the future. In short, the model implies that legislators face a trade-off between the desire to smooth the net benefits of government 
expenditures and their desire to spend (and save) funds while they control the means of allocation. As the prospects of controlling the means of allocation in the future diminish, the legislator will deviate from the smooth net benefits path in the current period. The model suggests that legislators will follow a 'help yourself first policy.' Even though private sector agents may prefer a smooth level of expenditures over time, once the legislator perceives his political survival or his prospects for political control are in jeopardy, he will choose to increase spending in the current period to maximize the (certain) net benefits of spending.

\subsubsection{The determinants of public sector saving}

The impact of all the state variables on current savings can be obtained from equation (3.5) given that savings in the current period, $S_{t}$, is defined as the difference between current revenue and current spending. Since revenue obtained by the state at time $t$ is exogenous to the choice of realized savings, equation (3.4) allows us to write savings as:

$$
S_{t}(\cdot)=R_{t}-G_{t}\left(r_{t}, A_{t}, R_{t},\left\{R_{t+k}\right\},\left\{P_{t+k}\right\},\left\{r_{t+k}\right\}\right) \text { for } k=1, \ldots, \infty \text {. }
$$

Since government expenditures at time $t$ depends on all future values of revenue, interest rates, and the probability of being reelected and part of the majority, current savings will also depend on these variables. Signing the effects of these variables on current expenditures gives us their a priori impact on the current level of savings. These comparative statics are derived in Appendix A.

The impact of current fungible assets $\left(A_{t}\right)$ and future revenue $\left(R_{t+1}\right)$ can be conclusively signed to negatively impact current savings. The model predicts that legislators save less in a given year when they have a larger stock of fungible assets at 
their disposal. Also, the model implies that when legislators expect increased revenue in the future they opt to increase current spending in favor of saving. Thus we have,

$$
\begin{aligned}
& \frac{\partial S_{t}}{\partial A_{t}}<0 \\
& \frac{\partial S_{t}}{\partial R_{t+k}}<0 \text { for } k=1, \ldots, \infty
\end{aligned}
$$

On the other hand, current revenue and the compound probability that the legislator is reelected and part of the majority in the coming election can be shown to have a positive impact on current saving. Hence,

$$
\begin{gathered}
\frac{\partial S_{t}}{\partial P_{t+1}}>0 \\
\frac{\partial S_{t}}{\partial R_{t}}>0
\end{gathered}
$$

However, in order for current revenue to positively impact current saving, it is sufficient that $\theta_{t}>\gamma_{t}$. The intuition of this condition is that legislators will opt to save in the face of increased revenue during any period in which his share of district expenditures exceeds his district's revenue share to ensure a smooth flow of net benefits to his district in the future.

Finally, both current and future interest rates can not be conclusively signed from the model. Thus,

$$
\begin{aligned}
& \frac{\partial S_{t}}{\partial r_{t}}>0 . \\
& \frac{\partial S_{t}}{\partial r_{t+k}}>0 \text { for } k=1, \ldots, \infty .
\end{aligned}
$$


Since no theoretical restrictions were placed on the state's fungible assets $\left(A_{t}\right)$, current interest rates ambiguously impact current saving. However, since it is likely that states will primarily hold positive wealth in practice, it is likely that increases in current interest rates will increase current spending (through the income effect) and reduce current saving. In short, while neither the impact of current nor future interest rates on current saving can be signed, it is likely that increases in current interest rates adversely impact current savings as a result of the income effect.

\subsection{Specifying the Empirical Model and Data Description}

\subsubsection{The empirical model}

A first-order linear approximation to equation (3.9) is estimated utilizing a two-way fixed effects model for 39 states. ${ }^{17}$ According to theory, equation (3.9) implies that current savings will depend on all future values of revenue, real interest rates, and the probability of being reelected and part of the majority. To keep the empirical model estimable, equation (3.9) is estimated using both one and two periods of future values. Given that legislators discount the future and the fact that a majority of states have at least one house following a two-year election cycle, it is unlikely that future values extending beyond two periods play a significant role in legislators' decisions. Formally, the one period fixedeffects model may be expressed as:

$$
S_{i t}=\phi+\eta_{i}+v_{t}+\beta_{1} r_{i t}+\beta_{2} A_{i t}+\beta_{3} R_{i t}+\beta_{4} r_{i t+1}+\beta_{5} R_{i t+1}+\beta_{6} P_{i t+1}+\varepsilon_{i t}
$$

${ }^{17}$ Generally in LCPI models researchers are interested in details regarding the form of the utility function so they tend to estimate the Euler equations directly. The focus of this chapter is not to obtain information regarding an average legislator's utility function, but rather to determine the extent to which changes in controlling political parties and reelection considerations influence states' current savings. 
where $\phi$ is the common constant term, $\eta_{i}$ are the state-specific effects, $v_{t}$ are the timespecific effects, $N$ is the state index, $T$ is the time index, and $\varepsilon_{i t}$ is the error term assumed to be uncorrelated over time and between states. According to theory, the primary hypothesis is that $\beta_{6}<0$, which implies that as a legislator's prospects for controlling political outcomes diminish, she will opt to increase current spending in favor of current saving. The model in Section 3.3 also implies that we should expect $\beta_{2}<0, \beta_{3}>0, \beta_{5}<$ 0 , and $\beta_{1}$ and $\beta_{4}$ ambiguous.

\subsubsection{Data Description and variable definition}

In the empirical model, $S_{i t}$ is state $i$ 's real per capita saving at time $t$, which is calculated as the difference between the change in the state's real general fund revenue and real general fund expenditures plus the real per capita change in the balance of the state's budget stabilization fund. This common formulation of savings addresses only the contributions to savings in a given year rather than the total quantity of savings available to allocate and is consistent with the definition employed in the theoretical model.

We define the state's fungible assets available at time $t\left(A_{t}\right)$ as the real per capita sum of the state's previous general fund position plus the state's previous real per capita budget stabilization fund balance. The definitions and source of all the variables are included in Table 3.1 .

$R_{i t}$ is state $i$ 's real per capita general fund revenue at time $t$ less any revenue surplus at time $t-1$. Since general fund surpluses at time $t-1$ is a component of the 


\section{Table 3.1 - Variables Employed in Political Control Empirical Model}

\begin{tabular}{|c|c|}
\hline$S_{i t}=$ & real per capita current savings of state $i$ at time $t$. [in dollars] ${ }^{1,2,5}$ \\
\hline$A_{i t}=$ & real per capita assets of state $i$ available at time $t$. [in dollars] ${ }^{1,2,5}$ \\
\hline$R_{i t}=$ & $\begin{array}{l}\text { real per capita general fund revenue of state } i \text { at time } t \text { less any } \\
\text { general fund revenue surplus at time } t-1 \text {. [in dollars] }]^{1,5}\end{array}$ \\
\hline$r_{i t}=$ & $\begin{array}{l}\text { real interest rate of state } i \text { 's twenty-year general obligation bonds } \\
\text { between at time } t .{ }^{3}\end{array}$ \\
\hline TURNOVER $_{i t+1}=$ & $\begin{array}{l}\text { weighted average of legislative turnover rate in state } i \text { 's lower } \\
\text { and upper house at time } t+1 \text {. [percent } * 100]^{4}\end{array}$ \\
\hline$\Delta$ Lower $_{i t+1}=$ & $\begin{array}{l}\text { ' } 1 \text { ' if there was a change in the controlling party of state } i \text { 's lower } \\
\text { house between time } t \text { and } t+1.4\end{array}$ \\
\hline$\Delta$ Upper $_{i t+1}=$ & $\begin{array}{l}1 \text { ' if there was a change in the controlling party of state } i \text { 's upper } \\
\text { house between time } t \text { and } t+1.4\end{array}$ \\
\hline \multicolumn{2}{|c|}{$\begin{array}{l}\text { Notes: All variables in real terms were deflated using the CPI }(1992=100) . \\
\text { Sources: } \\
{ }^{1} \text { Data on state general fund expenditures and revenue are from various issues of the Statistical } \\
\text { Abstract of the United States. } \\
{ }^{2} \text { Data on the balance of state budget stabilization funds were obtained from each individual state. } \\
{ }^{3} \text { The relative yield difference (from New Jersey) on twenty-year general obligation bonds was obtained } \\
\text { from the 'Chubb Relative Value Study', conducted biannually by the Chubb Corporation. The interest rate } \\
\text { for the benchmark state of New Jersey was approximated using the interest rate on Moody's index of ten- } \\
\text { year state general obligation bonds. See text for a thorough discussion of this variable. } \\
{ }^{4} \text { Data on the number of members in each political party and legislative turnover rates were obtained from } \\
\text { various issues of the Book of States and Statistical Abstract of the United States. } \\
5 \text { State population data were obtained from the Bureau of Economic Analysis, Department of the Census. }\end{array}$} \\
\hline
\end{tabular}

fungible assets available at time $t$, a collinearity problem will exist if the surplus revenue component is not subtracted from current revenue.

Moreover, data on state-level interest rates $\left(r_{i t}\right)$ were obtained from the Chubb

Relative Value Study which is conducted biannually by the Chubb Insurance Company.

This study provides information on the yield of twenty-year state general obligation

bonds relative to the benchmark state of New Jersey. Since bond yields on ten and

twenty-year municipal bonds are highly correlated, the yield on New Jersey's twenty-year 
general obligation bond is proxied using the nominal interest rate from Moody's Investor Services index of ten-year AAA state general obligation bonds. The interest rates for all remaining states are then computed from the New Jersey proxy using the data provided by the Chubb Relative Value Study. ${ }^{18}$

The probability that a legislator is reelected and part of the majority $\left(P_{i t+1}\right)$ is proxied using three variables. The probability that a legislator is reelected is proxied using the weighted average of legislative turnover rates (TURNOVER $\left.{ }_{i t+1}\right)$ in both houses of the state's legislature. ${ }^{19}$ The higher the turnover rate, the less likely a given legislator is to be reelected. Thus an increase in the turnover rate, which lowers the legislator's probability of being reelected and part of the majority, should reduce current saving in favor of current spending according to the theory. In addition, the probability that the majority party retains control over is proxied using binary variables of the actual change in the controlling party of each house in the state's legislature. If legislators are assumed to form their expectations regarding the future rationally, which implies that on average their expectation will be correct, we may approximate the ex ante change with the ex post

\footnotetext{
${ }^{18}$ The starting year of my sample was determined by the fact that the Chubb Relative Value Study did not begin until 1973. The Chubb Relative Value Study excludes the following states which do not issue general obligation bonds: AR, AZ, CT, IA, ID, IN, $\mathrm{KS}, \mathrm{NE}, \mathrm{SD}$, and WY. MN is also excluded from the sample because legislators in Minnesota were elected without party designation for several years in the sample period making it impossible to determine the controlling party. Bayoumi et al. (1995) previously used data from the Chubb Relative Value Study and their paper provides a more thorough explanation of the data and survey methodology. I would like to thank Thomas Swartz of the Chubb Insurance Company for his assistance in obtaining these data.

${ }^{19}$ I also examined the impact of turnover rates in states' legislatures using separate variables for both the lower house and upper house but found no qualitative difference in the empirical results.
} 
information. ${ }^{20}$ Hence, $\Delta$ Lower $_{i t+1}\left(\Delta\right.$ Upper $_{i t+1}$ ) takes on the value of 1 if the lower house (upper house) experienced a change in their controlling party between time $t$ and $t+1$, and is zero otherwise. This specification will allow us to ascertain the impact that an actual change (as a proxy for the anticipated change) in the controlling party had on the level of savings in a given year. According to the theory, a reduction in the probability that a legislator will remain part of the majority will cause him to forgo current saving in favor of current spending. Thus, we would expect $\Delta$ Lower $_{i t+1}$ and $\Delta$ Upper $_{i t+1}$ to exhibit a negative effect on current savings.

\subsubsection{Issues in estimation}

The use of a two-way fixed effects model for the empirical investigation can control for institutional factors not explicitly addressed in the theoretical model. The theoretical model ignores fiscal constraints such as balanced budget rules, expenditure and tax limit rules, and does not explicitly account for credit market conditions because they are not the primary focus of the chapter. However, there has been some evidence suggesting that these factors influence state fiscal behavior. ${ }^{21}$ Thus it is necessary to include the statespecific effects to control for any impact on individual states that such rules may have in order to isolate the impact of an anticipated change in the state's controlling parties. The

\footnotetext{
${ }^{20}$ Under the assumption of rational expectations, all values of future variables in the empirical model were approximated using actual values.

${ }^{21}$ Evidence that balanced budget rules affect state fiscal behavior can be found in von Hagen (1991), Poterba (1994, 1995), Alt and Lowry (1994), Bohn and Inman (1996), and Levinson (1998). Evidence that expenditure and tax limitation laws influence states can be found in Elder (1992). For research concerning the role of credit markets in affecting state behavior, see Goldstein and Woglom (1992), Bayoumi et al. (1995), and Poterba and Rueben (1997).
} 
inclusion of time-specific effects will absorb the impact that any aggregate economic shock may have on states.

In addition, the timing of states' elections causes the values of the political variables two periods in the future to be zero. Since the fiscal data are in fiscal years and the political data are in calendar years, fiscal year 1995 occurs simultaneously with election year 1994. Thus for the future political environment to affect current fiscal behavior as the theory suggests, the 1994 election year will only impact fiscal 1994 because the election is realized when savings decisions in 1995 have been made. Hence, the two period future values of TURNOVER ${ }_{i t+1}, \Delta$ Lower $_{i t+1}$, and $\Delta$ Upper $_{i t+1}$, which occurs simultaneously with fiscal year 1996, have no realization since the next elections occur in the subsequent year. As a result, these political variables have been excluded from the two future period model of equation (3.11).

Moreover, since the average real per capita savings of Alaska was \$2222 during the sample period (1973-1995) and its nearest neighbor was Delaware at $\$ 325$, the choice to include Alaska in the empirical model introduces heterogeneity which implies that Ordinary Least Squares (OLS) estimates of equation (3.11) will not be efficient. ${ }^{22}$ To compound the problem, Cochrane-Orcutt estimates of first-order serial correlation were computed separately for each state using the OLS residuals from both models. The results from the one period future model are presented in Table B1 in Appendix B and illustrate substantial heterogeneity across states. Since the data are pooled, a Generalized Methods of Moments (GMM) estimator is used to efficiently estimate the standard errors. I assume a general error covariance structure that allows for constant correlation within individual

\footnotetext{
${ }^{22}$ Excluding Alaska did not change the qualitative results of the model.
} 
states over time and constant correlation between states over time. These assumptions imply a covariance structure which may be written as:

$$
\Sigma=\left[\begin{array}{ccccc}
\sigma_{11} I & \sigma_{12} I & \ldots & \ldots & \sigma_{1 N} I \\
\sigma_{21} I & \sigma_{22} I & \ldots & \ldots & \ldots \\
\ldots & \ldots & \sigma_{33} I & \ldots & \ldots \\
\ldots & \ldots & \ldots & \ldots & \ldots \\
\sigma_{N 1} I & \ldots & \ldots & \ldots & \sigma_{N N} I
\end{array}\right]_{N T x N T}
$$

where $\Sigma$ is the error covariance matrix, $\sigma_{i j}$ is the covariance between the $i^{\text {th }}$ and $j^{\text {th }}$ states, and $I$ is an identity matrix with dimension $\mathrm{T} \times \mathrm{T}$. This system error covariance structure, which has dimension NT x NT, may also be expressed as $\Sigma=\sigma_{i j} A \otimes I$ for $i, j=1, \ldots, N$, where $A$ is a matrix of ones having dimension $\mathrm{N} \times \mathrm{N}$ and $\otimes$ is the Kronecker product. The GMM estimator for efficient standard errors is given by:

$$
\operatorname{Var}(\hat{\beta})=\left(X^{\prime} X\right)^{-1}\left(X^{\prime} \Sigma X\right)\left(X^{\prime} X\right)^{-1}
$$

where $X$ is the matrix of $\mathrm{K}$ regressors including the constant term, state-specific effects, and time-specific effects having dimension NT x $(\mathrm{K}+\mathrm{N}+\mathrm{T}-2)$.

\subsection{Estimation Results}

The estimation results of equation (3.11) with heterogeneity-corrected standard errors provide some interesting findings and are presented in Table 3.2. The model which includes two future values of real per capita revenue and real interest rates performs slightly better than the model which only includes values from one future period, but both models seem to fit the data very well as indicated by the significant F-Tests (both at the 1 percent level) and $\bar{R}^{2}$ in excess of 0.86 . 
Table 3.2 - Impact of Political Control on States' Current Savings

Dependent Variable: Current savings $\left(S_{i t}\right)$

\begin{tabular}{|c|c|c|}
\hline & One future period & Two future periods \\
\hline Variables & Sample period: 1973-1995 & Sample period: $1973-1994$ \\
\hline Constant $(\phi)$ & $\begin{array}{l}-1962.700^{* * * *} \\
(234.964)\end{array}$ & $\begin{array}{c}-2093.500^{* * *} \\
(210.820)\end{array}$ \\
\hline$A_{i t}$ & $\begin{array}{l}-0.159 \\
(0.177)\end{array}$ & $\begin{array}{l}-0.150 \\
(.108)\end{array}$ \\
\hline$R_{i t}$ & $\begin{array}{c}0.811^{* * *} \\
(0.120)\end{array}$ & $\begin{array}{c}0.881^{* * *} \\
(0.115)\end{array}$ \\
\hline$R_{i t+1}$ & $\begin{array}{l}-0.076 \\
(.106)\end{array}$ & $\begin{array}{l}-0.332^{* *} \\
(0.142)\end{array}$ \\
\hline$R_{i t+2}$ & -- & $\begin{array}{l}0.252^{* *} \\
(0.101)\end{array}$ \\
\hline$r_{i t}$ & $\begin{array}{l}-0.072 \\
(0.089)\end{array}$ & $\begin{array}{l}-0.061 \\
(0.082)\end{array}$ \\
\hline$r_{i t+1}$ & $\begin{array}{l}-0.039 \\
(0.089)\end{array}$ & $\begin{array}{l}-0.049 \\
(0.081)\end{array}$ \\
\hline$r_{i t+2}$ & -- & $\begin{array}{l}-0.139^{*} \\
(0.082)\end{array}$ \\
\hline Turnover $_{i t+1}$ & $\begin{array}{c}0.015 \\
(0.484)\end{array}$ & $\begin{array}{l}0.160 \\
(0.451)\end{array}$ \\
\hline$\Delta$ Lower $_{i t+1}$ & $\begin{array}{c}-70.145^{* * *} \\
(25.540)\end{array}$ & $\begin{array}{c}-66.343^{* * *} \\
(25.241)\end{array}$ \\
\hline$\Delta$ Upper $_{i t+1}$ & $\begin{array}{c}-4.531 \\
(55.520) \\
\end{array}$ & $\begin{array}{l}-21.020 \\
(53.95) \\
\end{array}$ \\
\hline $\begin{array}{l}\text { F-Test } \\
\text { ( } \Delta \text { Lower and } \Delta \text { Upper ) }\end{array}$ & $2.391^{*}$ & $2.409^{*}$ \\
\hline Sample size & 897 & 858 \\
\hline F-Test (Model) & $83.430^{* * *}$ & $92.110^{* * *}$ \\
\hline $\bar{R}^{2}$ & 0.862 & 0.880 \\
\hline
\end{tabular}

Notes: Significance levels are as follows: ${ }^{* * *}$ denotes significance at the 1 percent level, ${ }^{* *}$ at the 5 percent level, and ${ }^{*}$ at the 10 percent level. GMM standard errors in parentheses. Both models were estimated with fixed state-specific and time-specific effects that are not reported. 
With respect to the individual regressors, changes in the controlling parties of the states' houses $\left(\Delta\right.$ Lower $_{i t+1}$ and $\Delta$ Upper $_{i t+1}$ ) have the largest marginal effect on savings in both models in the direction predicted by the theory, yet only actual changes in the controlling party of the states lower house is statistically significant. As is evident from Table 3.2, an actual change in the controlling party of the lower house causes a reduction in the current real per capita savings by more than 70 dollars in the one period future model and more than 66 dollars in the two period future model, both significant at the 1 percent level. This finding is consistent with the theoretical implication that individual legislators will opt to increase current expenditures (and forgo current savings) when they anticipate that their ability to control the outcome in the future may be jeopardy. Moreover, the F-test for the joint significance of $\Delta$ Lower and $\Delta$ Upper reveal in each model that the variables are jointly significant at the 10 percent level. Thus, there is some evidence that the common pool of public sector savings may make states' current savings susceptible to systematic fluctuations. From the standpoint of policy, anticipated changes in the state's political structure prior to a fiscal crisis may adversely impact the state's prospects for a smooth recovery. One reason that current savings proves to be more responsive to changes in the controlling party of the state's lower house may be that many states require appropriations bills to originate in the lower house. ${ }^{23}$ According to the National Association of State Budget Offices (NASBO), fifteen states require that spending legislation begin in the lower house and several others require that the origin of such legislation changes between the lower and upper house with each legislative session.

\footnotetext{
${ }^{23}$ Legislative Budget Procedures: A Guide to Appropriations and Processes in the States, Commonwealths, and Territories, National Association of State Budget Offices.
} 
The variable included to capture the effect of reelection uncertainty, TURNOVER ${ }_{i t+1}$, has an estimated sign which is inconsistent with theory yet it is insignificantly different from zero. Considering that changes in the controlling party of the state's lower house is significant and the legislative turnover rate is not, the results suggest that states' savings responds much stronger to changes in the specific controlling party than simply to changes in membership.

Of the fiscal variables in the model, revenue proves to be the most significant determinant of current savings. In both the one and two period models, per capita revenue in the current period is significant at the 1 percent level. In the model incorporating fiscal variables from two future periods, all revenue variables are significant, but revenue two periods in advance $\left(R_{t+2}\right)$ is inconsistent with the model's theory. In addition, the estimated sign of the state's fungible assets $\left(A_{t}\right)$ is consistent with the theory, but it is also not statistically significant at least at the 10 percent level. With the exception of the two period in-advance interest rate $\left(r_{i t+2}\right)$, which is significant, the interest rate facing states proved to have very little influence on states' current savings decisions.

To summarize the empirical results, both models illustrate that current savings has been adversely affected by actual future changes in the controlling party of states' lower houses. This finding is consistent with the theoretical model's implication that legislators will forgo current saving in favor of current spending in the face of uncertainty regarding their future ability to control political outcomes, and it is also robust with respect to the inclusion of future fiscal variables. Hence, the empirical results provide support for the claim that legislators will increase current spending while they are ensured control over the means of allocation if their future control is in jeopardy. 


\subsection{Conclusions}

States are active savers and the use of savings as a fiscal policy tool for states has increased dramatically during the last two decades. Understanding the factors which influence a state's current savings can provide insights regarding states' abilities to deal with future fiscal crises. However, the decision-making process of the public sector induces additional complexities which are not present in simliar consumer optimization models. Since the group or political party which controls that state's legislature has tremendous influence over political outcomes due to agenda-setting power and blockvoting, and contintuation of this power is uncertain due to systematic elections, public sector savings suffers from the common pool problem. That is, no one political party which currently has control over political outcomes, and thus access to savings, can ever be certain that they will indefinitely control political outcomes in the future. If the spending preferences between parties is different, which research by Husted and Kenny (1997) and Gilligan and Matsusaka (1995) suggests, then expected changes in the state's future controlling party should adversely impact current savings as legislators opt to spend the funds while they are ensured control.

This chapter develops a simple extension of the basic LCPI model which can be used to analyze the effect of political reelection and political control on states' current saving. The model assumes a representative legislator that chooses the total level of government spending in each period of their infinite life to maximize the net benefits of government spending in his district, subject to the state's resource constraint. As the legislator's expected probability of being reelected and part of the majority party diminishes, and with it his chance for controlling future political outcomes, the 
legislator's optimal choice is to increase expenditures in the current period while he is ensured control of the means of allocation. If legislator's are assumed to be homogenous, then an anticipated change in the state's controlling party will increase the state's current expenditures and reduce current savings. Thus if legialators form expectations rationally, the model implies that states' current savings will be succetpible to systematic flucuations due to changes in the state's political environment.

Using a panel of 39 states over the period from 1973 to 1995, a two-way fixed effects model is estimated based on the theoretical model. Employing a binary variable for both the state's upper and lower house to capture the effect of an actual change in the future majority party, the empirical results provide evidence in support of the theory. The estimation results reveal that a change in the future controlling party of states' lower house is correlated with current real per capita savings falling by an average of more than 68 dollars. Thus, this chapter provides evidence that states' current savings may be influenced systematically by changes in the state's political environment, implying that politically stable states should, on average, save more than politically unstable states. Thus states' abilities to mitigate fiscal stress will be influenced by anticipated changes in states' political environments.

The next chapter examines the determinants of state budget stabilization fund adoption and investigates the role that political control may have had on states' choices. 


\section{Chapter 4}

\section{Determinants of State Budget Stabilization Fund Adoption}

\subsection{Introduction}

States have dramatically expanded their use of budget stabilization funds as a source of precautionary balances during the last twenty years. While New York became the first state to adopt a budget stabilization fund in 1945 , the majority of states did not adopt budget stabilization funds until after 1980. Of the 44 states currently utilizing budget stabilization funds, only 10 states adopted their stabilization fund prior to $1980 .{ }^{24}$ Although every year of the 1980s, with the exception of 1980 and 1989, witnessed states adopting stabilization funds for the first time, the bulk of stabilization fund adoption occurred between 1981 and 1986, when 20 states adopted funds. The conventional view regarding the increase in stabilization fund usage that occurred during the 1980s, which has been advocated by Gold (1983) and Sobel and Holcombe (1996a), is that states adopted stabilization funds in response to the severity of the 1980-1982 recession. This view holds that states adopted stabilization funds because the lack of reserves that existed prior to the recession forced states to rely heavily on expenditure cuts and tax increases to mitigate the recession's impact. The purpose of this chapter is to investigate the factors that influenced states' decisions to adopt budget stabilization funds.

Research by Sobel and Holcombe (1996a), Levinson (1998), and Knight and Levinson (1999a) suggests that budget stabilization funds may be an effective means to

\footnotetext{
${ }^{24}$ The states which do not have budget stabilization funds as of 1998 include AL, AR, HI, IL, MT, and OR. While Alabama has a budget stabilization fund, it may only be used for the education portion of their budget, and thus is not a stabilization account for the state's general fund.
} 
enhancing a state's fiscal health. Levinson (1998) finds that states with budget stabilization funds experienced less volatile business cycles than states that did not possess stabilization funds, and Sobel and Holcombe (1996a) find that states with well structured budget stabilization funds experienced fewer reductions in expenditures below their long-run growth rate during the 1990-1991 recession than did states without stabilization funds.

More recently, Knight and Levinson (1999a) find that states with budget stabilization funds save more than states without budget stabilization funds and that states' total balances are higher after adopting a budget stabilization fund, suggesting that budget stabilization funds do in fact enhance states' fiscal positions and their abilities to remedy revenue shortfalls.

From a theoretical standpoint it does not matter whether states save funds only in a stabilization fund, only in the general fund, or both, since general fund surpluses and budget stabilization fund balances earn the same market return and are both subject to inflation risk and systematic risk. There are however several potential advantages to retaining monies in a budget stabilization fund rather than the general fund which may play a role in a state's decision to adopt a budget stabilization fund. First, unlike the federal government most states face numerous fiscal constraints, such as balanced budget laws and tax and expenditure limitation laws, which may limit their decision-makers' options in the event of a revenue shortfall. In fact, expenditure laws in some states mandate that a fraction of any general fund surplus be returned to citizens. Hence adopting a budget stabilization fund may provide a state with a means to circumvent such fiscal limitations. 
Second, a state's decision-makers may collectively decide to save funds in a budget stabilization fund as opposed to the general fund as a means to avoid political manipulation by legislators for self-gain since greater restrictions can be placed on the use of budget stabilization fund balances than can be placed on general fund balances. Political manipulation of a state's stock of savings may occur in a number of ways. First, Weingast et al. (1981) developed a model in which legislators have a strong incentive to spend more than is efficient since the political structure (i.e. political districts) allows legislators to provide centralized benefits of government expenditures with decentralized costs. The excess spending in their model derives from the fact that the public sector tax base is a common pool. In fact, Weingast et al. show that the difference between the efficient level of government spending and the actual level of government spending increases as the number of political districts increases because the opportunities to localize the benefits of government spending while spreading the costs expand.

An empirical test of the Weingast et al. model, conducted by Gilligan and Matsusaka (1995) using state-level data over the period from 1960-1990, found that expenditures are positively correlated with the number of seats in the upper house of a state's legislature. ${ }^{25}$ So if legislators face a strong incentive to spend excessively, the demands they place on surplus funds may be quite high. Thus, one political motive for adopting a budget stabilization fund may represent somewhat of a prisoner's dilemma scenario. Individually, legislators may each prefer to spend any general fund surplus in accordance with her preferences. However, given Sobel's (1998) finding that expenditure

\footnotetext{
${ }^{25}$ Gilligan and Matsusaka (1995) also find that the level of state government spending is greater than can be explained by variables reflecting constituent interests which suggests that the spending may be inefficiently high.
} 
reductions and tax increases significantly increased states' legislative turnover rates, the potential benefits to legislators from saving the funds may be so high that legislators opt to establish a stabilization fund to retain surplus funds.

The notion that individuals may voluntarily select collective constraints governing their behavior is not a novel idea. As Buchanan (1990, p. 4) has noted:

"It is essential to acknowledge, near the outset of the discussion, that individuals choose to impose constraints or limits on their own behavior primarily, if not exclusively, as part of an exchange in which the benefits they are anticipated from the reciprocally extended restrictions on the actions of others with whom they interact along the boundaries of private spaces and within the confines of acknowledged public spaces."

The fact that most states now have budget stabilization funds may arise from the cooperative agreement of individual legislators, despite the fact that each may increase his or her own utility by spending surplus funds. Buchanan also notes that "a necessary condition for cooperation in social interaction is the prospect for positive expected gains by all parties, or, in the gainer-loser terminology, the prospect that there be no net losers." Thus if states' decision-makers perceive budget stabilization funds as a viable means of saving which ensures positive gains to all involved, they may collectively agree to establish a reserve account.

Next, general fund surpluses may also succumb to political manipulation as a result of the common pool problem associated with public sector savings. Since legislators who control the political outcome have the means to allocate spending as they desire, an anticipated change in the state's controlling parties may adversely affect the current level of savings because legislators in control may decide to spend existing balances and reduce current saving while they are ensured the voting power to dictate the 
composition of spending. Chapter 3, which estimates a panel of states over the period from 1973-1995, finds empirical support for this claim. However, the results from Chapter 3 illustrate the impact of a one-time anticipated change in states' controlling parties on states' current level of savings. The findings of Chapter 3 imply that over a much longer period of time states which have experienced more changes in political control will witness greater reductions in their current savings than states which have been politically stable, all other factors constant. This suggests that if states' decisionmakers are aware that they may be better off when the funds are saved, meaning no "net losers" in the spirit of Buchanan, then states which have experienced more changes in political control over the long-run will have more to gain from saving than states which have experienced very little long-term political instability. As a result, decision-makers in states that have a long-run problem with political instability may establish a stabilization account in an effort to reduce political manipulation resulting from the common pool problem.

A final potential advantage of budget stabilization funds is that states' decisionmakers may perceive such instruments as a means to continue, or enhance, fiscal discipline. States' decision-makers that have not had the fiscal discipline necessary to save monies in the general fund may choose to adopt a budget stabilization fund in the hopes of enhancing their fiscal health. In contrast, states whose legislators are committed to saving may decide to adopt a budget stabilization fund as a way to ensure fiscal health is maintained. Moreover, since bond rating agencies consider a state's ability to mitigate periods of fiscal stress in their rating calculus, a state's decision-makers may decide to 
utilize a budget stabilization fund as a way to ensure the state's bond ratings are not lowered.

Using data on the year of adoption for each state's budget stabilization fund, a panel probit model is estimated over the period from 1945-1996 to examine the role that state fiscal limitations, economic conditions, political climate, and commitment to saving have had on states' decisions to adopt stabilization funds. The empirical results provide evidence consistent with the notion that political control has influenced states' choices. I find that states which have experienced more changes in political control over the previous twenty years are more likely to adopt budget stabilization funds. This suggests that decision-makers in states that have a long-term problem with political instability may see budget stabilization funds as a means to reduce systematic political manipulation of their savings.

The estimates also reveal evidence consistent with a political prisoner's dilemma motive for adopting a stabilization fund since the number of seats in states' upper houses is positively correlated with adoption. In addition, I also find that states hit harder during recessions are more likely to adopt stabilization funds, which is likely to explain a fraction of the large number of adoptions that occurred during the 1980s. However, the empirical results also indicate that the existence of both tax and expenditure limitation laws significantly increases the probability a state will adopt a budget stabilization fund. This finding is important because it provides evidence that many states which adopted stabilization funds in the mid-1980s probably did so in response to the 'tax revolt' rather than the 1980-1982 recession. Finally, I find that the unpredictability of states' revenue 
over the business cycle and the state's current fiscal condition are also significant determinants of stabilization fund adoption.

The remainder of the chapter proceeds as follows: Section 4.2 briefly examines states' saving and their reliance on budget stabilization funds, Section 4.3 outlines the empirical methodology, Section 4.4 presents the empirical results, and Section 4.5 concludes the chapter.

\subsection{States' Reliance on Budget Stabilization Funds}

While states save to help mitigate periods of fiscal stress, the motivation for doing so may be as much political as it is economic. In the absence of savings, states must either use deficit financing (when permitted) and/or rely on expenditure reductions and tax increases to remedy revenue shortfalls. ${ }^{26}$ Given Sobel's (1998) finding that expenditure reductions and tax increases significantly increased states' legislative turnover rates, states' decision-makers would appear to face a strong incentive to save as an additional option to weather recessions. Relying heavily on tax increases and expenditure reductions during an economic downturn could prolong the recession by reducing private sector expenditures. Moreover, the issuance of new debt, while potentially beneficial in the short-run, may be harmful if systematically selected as a policy choice if a state's bond ratings are reduced since the state will face increased costs for capital investment and other borrowing in the future.

\footnotetext{
${ }^{26}$ According to Gold (1995) and Fisher (1996) states may also rely on accounting gimmicks, such as accelerating tax collections, to temporarily delay deficits.
} 
The majority of aggregate state savings continues to be retained in the general fund despite the dramatic increase in the number of states utilizing budget stabilization funds over the last two decades. Cross-sectional evidence that states' general funds are the primary instrument of saving is provided in Table 4.1, which reports fiscal-year-end balances of each state's stabilization fund and general fund. Only 12 states had budget stabilization fund balances at the end of fiscal year 1996 that exceeded the state's general fund balance. In fact as Figure 4.1 shows, since 1975 the aggregate share of total balances retained in budget stabilization funds has rarely been higher than 50 percent. Over this period states have retained an average of slightly more than 20 percent of total balances in budget stabilization funds. The large dip in Figure 4.1 which occurred in fiscal year

Figure 4.1 - Aggregate Budget Stabilization Fund Balances as a Percentage of Aggregate Total Balances 1975-1996

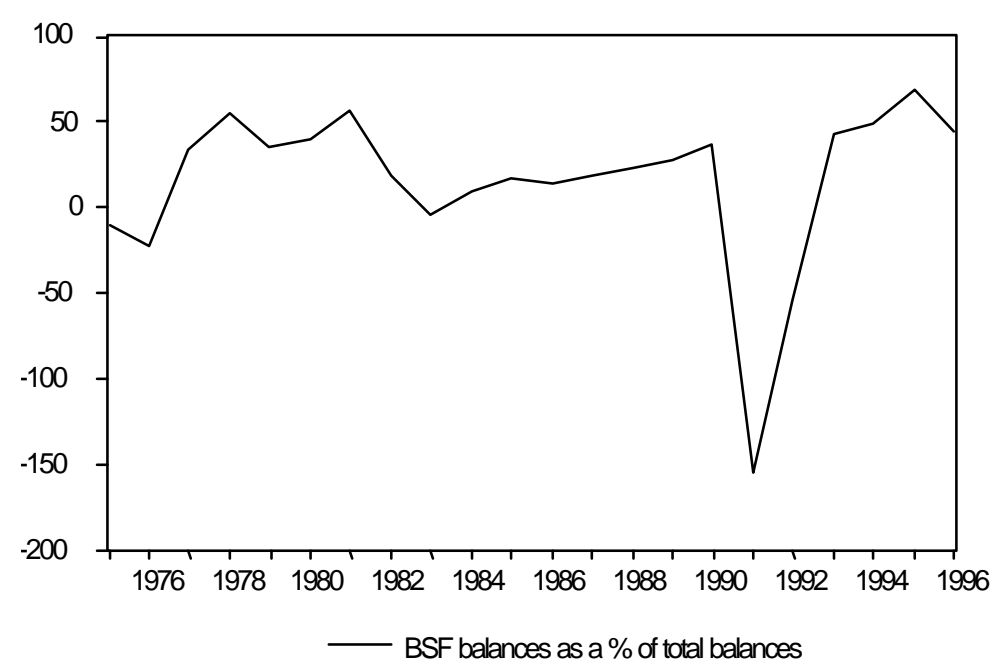

Notes: Only includes states which have stabilization funds.

1992, is the result of a small aggregate general fund deficit and a larger positive aggregate stabilization fund balance. Since only 29 states are prohibited by balanced budget laws from running general fund deficits in a given fiscal year, the fiscal strain 
generated by the recession resulted in many states witnessing significant deficits in their general fund along with massive reductions in budget stabilization fund balances.

While monies retained in budget stabilization funds represent a minority of total balances in the aggregate, states' experiences with stabilization funds are suggestive that their decision-makers believe they are a useful means of saving. As is evident from Table 4.1, California, Iowa, and New Mexico each utilized a stabilization fund, which was authorized annually by appropriations legislation, prior to formal adoption. In fact, New Mexico began utilizing their stabilization fund informally 12 years before the fund was continuously adopted. One would imagine that if the decision-makers in these states did not obtain benefits from utilizing a budget stabilization fund, they could have simply chosen not to make the fund a continuous account.

Additional anecdotal evidence of decision-makers' perception of stabilization fund effectiveness may be derived from the fact that several states have adopted multiple funds and no state has removed a stabilization fund without replacing the fund with a similar vehicle for saving. In Idaho for example, a stabilization fund was initially adopted in 1984, which was entitled the Budget Reserve Fund, but this fund was replaced July 1, 1999 by the Budget Stabilization Fund. Both the Budget Reserve Fund and Budget Stabilization Fund served the purpose of providing fungible balances, but the Budget Stabilization Fund placed greater restrictions on the manner in which funds are to be deposited and withdrawn. ${ }^{27}$

\footnotetext{
${ }^{27}$ See Idaho Code 59.814.
} 
Table 4.1 - Adoption Dates of State Budget Stabilization Funds

\begin{tabular}{|c|c|c|c|c|c|}
\hline$\overline{\text { State }}$ & Fund Name & $\begin{array}{c}\text { Year of first } \\
\text { Use } \\
\end{array}$ & $\begin{array}{c}\text { Year of formal } \\
\text { Adoption }\end{array}$ & $\begin{array}{c}\text { Real per capita BSF } \\
\text { balance } 1996^{\dagger}\end{array}$ & $\begin{array}{c}\text { Real per capita General } \\
\text { Fund balance } 1996 \\
\end{array}$ \\
\hline $\mathrm{AK}$ & Budget Reserve Fund & 1986 & 1986 & & \\
\hline AK & Constitutional Budget Reserve & 1990 & 1990 & $\$ 6.49$ & $\$ 2534.38$ \\
\hline $\mathrm{AL}$ & -- & -- & -- & -- & $-\$ 20.64$ \\
\hline $\mathrm{AZ}$ & Budget Stabilization Fund & 1990 & 1990 & $\$ 47.64$ & $\$ 10.01$ \\
\hline AR & -- & -- & -- & -- & $\$ 195.14$ \\
\hline $\mathrm{CA}$ & $\begin{array}{l}\text { Special Fund for Economic } \\
\text { Uncertainties }\end{array}$ & 1976 & 1985 & $\$ 3.12$ & $-\$ 17.00$ \\
\hline $\mathrm{CO}$ & $\begin{array}{l}\text { Required Fund Balance } \\
\text { (non-accumulating) }\end{array}$ & 1983 & 1983 & $\$ 36.74$ & $\$ 131.65$ \\
\hline $\mathrm{CT}$ & Budget Reserve Fund & 1979 & 1979 & $\$ 22.25$ & $\$ 171.71$ \\
\hline DE & Budget Reserve Account & 1977 & 1977 & $\$ 109.75$ & $\$ 474.51$ \\
\hline FL & Working Capital Fund & 1959 & 1959 & & \\
\hline FL & Budget Stabilization Fund & 1992 & 1992 & $\$ 25.89$ & $-\$ 39.36$ \\
\hline GA & Revenue Shortfall Reserve & 1976 & 1976 & $\$ 38.41$ & $-\$ 29.91$ \\
\hline $\mathrm{HI}$ & -- & -- & -- & -- & $\$ 113.42$ \\
\hline ID & Budget Stabilization Fund & 1984 & 1984 & $\$ 24.19$ & $\$ 168.36$ \\
\hline IL & -- & -- & -- & -- & $\$ 16.31$ \\
\hline IN & $\begin{array}{l}\text { Counter-Cyclical Revenue and } \\
\text { Economic Stabilization Fund }\end{array}$ & 1982 & 1982 & $\$ 68.61$ & $\$ 100.38$ \\
\hline IA & Cash Reserve Fund & 1984 & 1994 & & \\
\hline IA & Economic Emergency Fund & 1984 & 1992 & $\$ 113.65$ & $-\$ 15.88$ \\
\hline KY & $\begin{array}{c}\text { Budget Reserve Trust Fund } \\
\text { Account }\end{array}$ & 1983 & 1983 & $\$ 46.80$ & $\$ 226.51$ \\
\hline $\mathrm{KS}$ & General Fund Ending Balance & 1993 & 1993 & $\$ 0$ & $\$ 68.90$ \\
\hline LA & $\begin{array}{c}\text { Revenue Stabilization and Mineral } \\
\text { Trust Fund }\end{array}$ & 1990 & 1990 & $\$ 0$ & $-\$ 157.00$ \\
\hline ME & Rainy Day Fund & 1985 & 1985 & $\$ 27.78$ & $\$ 73.45$ \\
\hline MD & Revenue Stabilization Account & 1986 & 1986 & $\$ 82.63$ & $\$ 117.53$ \\
\hline MA & Commonwealth Stabilization Fund & 1986 & 1986 & $\$ 80.49$ & $\$ 8.15$ \\
\hline MI & $\begin{array}{l}\text { Countercyclical Budget and } \\
\text { Economic Stabilization Fund }\end{array}$ & 1977 & 1977 & $\$ 107.66$ & $\$ 45.65$ \\
\hline
\end{tabular}




\begin{tabular}{|c|c|c|c|c|c|}
\hline State & Fund Name & $\begin{array}{c}\text { Year of first } \\
\text { Use }\end{array}$ & $\begin{array}{l}\text { Year of formal } \\
\text { Adoption }\end{array}$ & $\begin{array}{c}\text { Real per capita BSF } \\
\text { balance } 1996^{\dagger}\end{array}$ & $\begin{array}{c}\text { Real per capita General } \\
\text { Fund balance } 1996\end{array}$ \\
\hline MN & Budget Reserve Account & 1981 & 1981 & & \\
\hline $\mathrm{MN}$ & Cash Flow Account & 1995 & 1995 & $\$ 111.59$ & $\$ 87.72$ \\
\hline MS & $\begin{array}{c}\text { Working Cash Stabilization Reserve } \\
\text { Fund }\end{array}$ & 1982 & 1982 & $\$ 68.36$ & $\$ 7.99$ \\
\hline MO & Budget Stabilization Fund & 1992 & 1992 & $\$ 4.91$ & $\$ 215.42$ \\
\hline MT & -- & -- & -- & -- & $\$ 106.23$ \\
\hline $\mathrm{NC}$ & Savings Reserve Account & 1991 & 1991 & $\$ 61.84$ & $\$ 78.63$ \\
\hline ND & Budget Stabilization Fund & 1987 & 1987 & $\$ 0$ & $\$ 398.64$ \\
\hline $\mathrm{NE}$ & Cash Reserve Fund & 1983 & 1983 & $\$ 9.91$ & $\$ 117.62$ \\
\hline $\mathrm{NH}$ & $\begin{array}{c}\text { Revenue Stabilization Reserve } \\
\text { Account }\end{array}$ & 1987 & 1987 & $\$ 15.58$ & $\$ 105.19$ \\
\hline $\mathrm{NJ}$ & Surplus Revenue Fund & 1990 & 1990 & $\$ 30.79$ & $\$ 65.60$ \\
\hline NY & Tax Stabilization Reserve Fund & 1945 & 1945 & & \\
\hline NY & Constitutional Reserve Fund & 1993 & 1993 & $\$ 11.75$ & $\$ 116.73$ \\
\hline NM & Tax Stabilization Reserve & 1966 & 1978 & $\$ 61.28$ & $\$ 50.76$ \\
\hline NV & Budget Stabilization Designation & 1994 & 1994 & $\$ 69.21$ & $\$ 68.65$ \\
\hline $\mathrm{OH}$ & Budget Stabilization Fund & 1981 & 1981 & $\$ 67.56$ & $\$ 79.53$ \\
\hline OK & Constitutional Reserve Fund & 1985 & 1985 & $\$ 31.36$ & $\$ 66.95$ \\
\hline OR & -- & -- & -- & -- & $\$ 91.98$ \\
\hline PA & Tax Stabilization Reserve Fund & 1985 & 1985 & $\$ 13.81$ & $\$ 28.29$ \\
\hline RI & $\begin{array}{l}\text { Budget Reserve and Cash } \\
\text { Stabilization Account }\end{array}$ & 1985 & 1985 & $\$ 48.22$ & $-\$ 49.41$ \\
\hline $\mathrm{SC}$ & General Reserve Fund & 1978 & 1978 & & \\
\hline $\mathrm{SC}$ & Capital Reserve Fund & 1986 & 1986 & $\$ 48.76$ & $-\$ 102.32$ \\
\hline SD & Budget Reserve Fund & 1991 & 1991 & $\$ 22.33$ & $\$ 30.68$ \\
\hline $\mathrm{TN}$ & Revenue Fluctuation Reserve & 1972 & 1972 & $\$ 17.26$ & $-\$ 63.85$ \\
\hline TX & Economic Stabilization Fund & 1987 & 1987 & $\$ 0.37$ & $\$ 51.48$ \\
\hline UT & Budget Reserve Account & 1986 & 1986 & $\$ 31.88$ & $\$ 75.02$ \\
\hline VA & Revenue Stabilization Fund & 1992 & 1992 & $\$ 11.52$ & $\$ 42.03$ \\
\hline VT & Budget Stabilization Trust Fund & 1988 & 1988 & $\$ 7.44$ & $\$ 49.60$ \\
\hline WA & Emergency Reserve Fund & 1981 & 1981 & $\$ 0$ & $-\$ 64.32$ \\
\hline WI & Required Reserve & 1981 & 1981 & & \\
\hline WI & Budget Stabilization Fund & 1985 & 1985 & $\$ 102.23$ & $\$ 144.12$ \\
\hline WV & Revenue Shortfall Reserve Fund & 1994 & 1994 & $\$ 27.03$ & $\$ 105.27$ \\
\hline
\end{tabular}




\begin{tabular}{|c|c|c|c|c|c|}
\hline State & Fund Name & $\begin{array}{c}\text { Year of first } \\
\text { Use }\end{array}$ & $\begin{array}{c}\text { Year of formal } \\
\text { Adoption } \\
\end{array}$ & $\begin{array}{c}\text { Real per capita BSF } \\
\text { balance } 1996^{\dagger}\end{array}$ & $\begin{array}{c}\text { Real per capita General } \\
\text { Fund balance } 1996\end{array}$ \\
\hline$\overline{\mathrm{WY}}$ & Budget Reserve Account & 1982 & 1982 & $\$ 8.03$ & $\$ 368.04$ \\
\hline
\end{tabular}

Source: Phone survey of states.

${ }^{\dagger}$ For states with multiple funds, per capita budget stabilization fund balance is the sum of all funds. 
Given that previous research and states' uses of budget stabilization funds over time suggest that they are an effective means to enhancing saving, it is somewhat surprising that not all states have selected to utilize stabilization funds. The following section of the chapter outlines the empirical methodology used to investigate the determinants of state budget stabilization fund adoption.

\subsection{Empirical Methodology}

\subsubsection{Empirical model}

To investigate the determinants of state budget stabilization fund adoption, a panel probit model is estimated over the period from $1945-1996 .{ }^{28}$ Since it is of primary interest to examine the determinants of states' decisions to adopt budget stabilization funds, we assume that once a state has adopted a budget stabilization fund it becomes an irreversible choice. That is, once a state adopts a budget stabilization fund no further observations from the state are included in the sample. The results from the model are therefore conditional on never having adopted a stabilization fund. ${ }^{29}$ The interpretation of the estimated parameters isolates the role the exogenous variables played in influencing a

\footnotetext{
28 The dates of first use rather than formal adoption are used in the empirical model (see Table 4.1). In addition, states that have multiple stabilization funds are included in the model using the date the first fund was adopted. A panel probit model was selected over a parametric or Cox proportional hazard model because both types of hazard models require the selection of an explicit starting date and the Cox proportional model further assumes that the baseline hazard is the same for each state at a given point in time.

${ }^{29}$ Moreover, excluding observations after a state adopts greatly simplifies the empirical methodology due to the possibility of simultaneity bias. If one or more of the regressors in the model changes after a state adopts a fund, then a simultaneous equations framework must by employed.
} 
state's choice to adopt a stabilization rather than their role in influencing a state's decision to adopt and retain a stabilization fund.

The general form of the model estimated may be expressed as:

$$
y_{i t}^{*}=x_{i t} \beta+\varepsilon_{i t} \quad \text { for } i=1, \ldots, N ; t=1, \ldots, T \text {. }
$$

where $x_{i t}$ is a $k$-dimensional vector of observed exogenous variables, $\beta$ is an unknown parameter vector to be estimated, $N$ is the state index, $T$ is the time index, and $\varepsilon_{i t}$ is the unobserved disturbance assumed to be distributed i.i.d. $\mathrm{N}\left(0, \sigma^{2}\right) \cdot{ }^{30}$ In addition, we do not observe $y_{i t}^{*}$ directly, rather we observe a censored form of $y_{i t}^{*}$ where:

$$
y_{i t}= \begin{cases}1 & \text { if } y_{i t}^{*}>0 \\ 0 & \text { otherwise }\end{cases}
$$

Given the assumption placed on the disturbance term, we may express as the conditional probability of adopting a budget stabilization fund as $\operatorname{prob}\left(y_{i t}=1 \mid x, \beta\right)=\Phi\left(x_{i t} \beta\right)$, where $\Phi$ denotes the standard normal cumulative distribution function. The log-likelihood function for this problem may then be written as:

$$
\tilde{a}(y, x ; \boldsymbol{\beta})=\sum_{i=1}^{N} \sum_{t=1}^{T}\left\{y_{i t} \ln \Phi\left(x_{i t} \beta\right)+\left(1-y_{i t}\right) \ln \left[1-\Phi\left(x_{i t} \beta\right)\right]\right\} \text {. }
$$

\footnotetext{
${ }^{30}$ Relaxing the assumption of error independence was investigated by assuming the commonly employed random effects panel probit model. The estimate of the equicorrelation coefficient, computed using Butler's and Moffit's (1982) Hermite integration technique, could not be rejected as significantly different from zero at conventional confidence levels.
} 
From the log likelihood function it is possible to show that the pooled probit estimator is given by: $:^{31}$

$$
\hat{\beta}=\arg \max _{\beta} \frac{1}{N} \sum_{i=1}^{N} \sum_{t=1}^{T}\left\{y_{i t} \ln \Phi\left(x_{i t} \beta\right)+\left(1-y_{i t}\right) \ln \left[1-\Phi\left(x_{i t} \beta\right)\right]\right\} .
$$

In addition to estimating the parameter vector that maximizes the log-likelihood function, marginal effects of the exogenous variables on the probability of adoption are also computed at the mean of the regressors. From the log-likelihood function expressed in equation (4.3), we may write the marginal coefficient vector as $\delta=\phi\left(\bar{x}_{i t} \beta\right) \beta$, where $\phi$ is the standard normal density function and $\bar{x}_{i t}$ is the mean vector of the regressors.

The next section of the chapter describes the regressors employed in the model and the estimation results are subsequently presented in Section 4.4.

\subsubsection{Factors in stabilization fund adoption}

\subsubsection{Political Factors}

As alluded to in the introduction of this chapter, a state's inability to save in the general fund due to political manipulation by legislators for self-gain may represent an influential factor in states' decisions to adopt a stabilization fund. If a state's decision-makers have an incentive to spend inefficiently and therefore place high demands on surplus balances, legislators may collectively decide to save these surplus balances in a budget stabilization fund if the benefits to doing so are high enough even though each legislator may individually prefer to spend the surplus. To account for the prisoner's dilemma motive for

\footnotetext{
${ }^{31}$ Recently, Bertschek and Lechner (1998) have shown that a class of GMM estimators attains greater efficiency than does the pooled estimator. Despite the inefficiency of the pooled estimator, Avery et al. (1983) have shown that it remains consistent.
} 
adopting a stabilization fund when legislators face an incentive to spend inefficiently, the number of seats in the lower house and upper house of each state's legislature is included in the model. We use the number of members as a proxy for the number of seats. The number of members is obtained from various issues of the Statistical Abstract of the United States and the Book of States.

Moreover, the common pool problem associated with public sector savings may make such balances susceptible to political manipulation. Since legislators with the ability to control the political outcome determine the manner in which public sector funds are allocated, a legislator may opt to forgo current saving in favor of current spending if his prospects for controlling the political outcome in the future diminish. In short, legislators may face an incentive to spend funds when they are ensured control over the allocation of such funds. Thus to avoid such political manipulation of savings, legislators may collectively opt to retain funds in a budget stabilization fund since such accounts can be structured to reduce discretionary influence. While the empirical results from Chapter 3 provide an estimate of the impact of a one-time, or short-run, anticipated change in the controlling parties of states' legislatures on the current level of savings, the incentive to adopt a budget stabilization fund as means to reduce political manipulation will be dependent on the long-run experience of states. All other factors constant, a state which has witnessed more political instability than another state will, on average, have a lower level of current savings. Since all legislators may benefit from having reserve balances available during a contraction, decision-makers in states which have experienced more political instability over the long-run will have more to gain from saving and thus may be more likely to choose to constrain their own behavior by adopting a budget stabilization 
fund. To account for the impact of political control, the total number of changes in the controlling party of both states' houses over the previous twenty-year period is included in the model. We would expect that states which have experienced more changes in political control over the long-run to be more likely to adopt a stabilization fund, ceteris paribus, since the decision-makers in these states have more to gain from saving relative to decision-makers in states which are politically stable. ${ }^{32}$

\subsubsection{Fiscal Constraints}

In addition to political motives, states face a complex set of fiscal constraints which may limit their ability to raise revenue in the short-run, and thus may increase the likelihood that a state will adopt a budget stabilization fund. One such constraint that has been shown to be correlated with state fiscal behavior is balanced budget laws. While balanced budget laws are aimed at controlling public sector deficits, most states' laws are imposed prior to the start of the fiscal year and thus impose no significant constraint on states' fiscal behavior (ACIR, 1987). The Advisory Commission on Intergovernmental Relations

\footnotetext{
32 The choice to model a twenty-year time period is derived from the fact that exploring the impact of long-term political stability requires a sufficiently long time period. The lack of data on the composition of states' legislatures prior to 1936 limited the time period that could be employed. The total number of changes in political control in 1945 is the sum of the number of changes in the state's lower house and upper house between 1936 and 1944. Figures for 1946 to 1955 were computed using data from 1936 to one year prior to each respective year. Beginning in 1956 and continuing to 1996, figures were computed using the previous twenty-year period. In addition, I also explored using separate variables for the state's lower and upper house, but the number of changes in each house was highly positively correlated over such a long time horizon. Estimating the model separately with only the lower house and only the upper house revealed that each was significant at the 10 percent level; however, when the number of changes in both the lower house and upper house were included neither was significant due to the correlation between them. As a result, I have chosen to include the sum of the number of changes in the lower house and upper house.
} 
has classified state balanced budget laws into five categories. First, the state's governor is required to submit a balanced budget; second, the state's legislature is required to adopt a balanced budget; third, the state may carry a budget deficit into the next fiscal year so long as it to be corrected in the upcoming fiscal year; fourth, the state may not carry forward a budget deficit into the next budget cycle; and finally, the state may not carry forward a budget deficit into the next fiscal year. Of these five categories, only the categories that prohibit deficits to be carried forward into future fiscal years or future budget cycles impose end-of-the-year limits.

Empirical evidence by Poterba (1994), Alt and Lowry (1994), Bohn and Inman (1996), and Levinson (1998) suggests that strict balanced budget rules, such as those which require fiscal-year-end adjustments, have more influence on decision-makers' fiscal behavior than less stringent laws. In particular, Poterba (1994) finds that in response to a $\$ 100$ unanticipated shock, states with stringent balanced budget rules adjust expenditures and taxes a total of $\$ 120$ dollars. This is consistent with the findings of Bohn and Inman (1996) and Alt and Lowry (1994), who find that states with strict balanced budget rules are associated with higher levels of per capita savings. Bohn and Inman also find that the annual probability of running a deficit is smaller for states with strict anti-deficit rules, and they claim that these states use savings as a means to ensure that fiscal limits do not bind. Thus the evidence seems to suggest that states with stringent balanced budget rules in place may be more likely to adopt budget stabilization funds than states with weak balanced budget rules since the states with strict rules are precluded from deficit financing and thus may have a greater demand for precautionary balances to avoid spending cuts and/or tax increases during recessions. To account for the potential 
influence of state balanced budget rules, a binary variable is constructed to coincide with each of the ACIR's (1987) five categories of balanced budget rules. ${ }^{33}$ We would expect stringent balanced budget rules to be positively correlated with states' adoption choice, and weak balanced budget rules to be uncorrelated with stabilization fund adoption, ceteris paribus.

In addition to controlling for specific balanced budget rules, Bohn and Inman (1996) find that enforcement of fiscal rules is also a significant factor affecting state fiscal behavior. They find that elected supreme courts, rather than appointed supreme courts, are associated with larger state general fund surpluses, suggesting that outsiders are more likely to enforce existing fiscal rules. To control for the potential impact of supreme court oversight, a binary variable is included in the model and equal to unity of the state has an elected supreme court, and equals zero otherwise. Data on whether state supreme courts are elected or appointed are from Bohn and Inman (1996) and are assumed to be constant over time.

Moreover, states' choices of savings instruments may also be influenced by the existence of expenditure and tax limitation laws. Despite the somewhat mixed empirical evidence regarding the ability of expenditure and tax limitation laws to limit the growth in public sector spending, both types of constraints have the potential to be tremendously

\footnotetext{
${ }^{33}$ Each state's balanced budget classification is from ACIR (1987). In addition, the ACIR's study indicates that many states' balanced budget rules have been in place since the $19^{\text {th }}$ century, and only Tennessee's classification changed from 'weak' to stringent in 1977, which is after they adopted their stabilization fund. Thus, the balanced budget rule binary variables for each state are constant throughout the sample period.
} 
influential as to the manner in which states save. ${ }^{34}$ In the case of revenue limitation laws, states may find their ability to increase revenue greatly hampered in a severe recession. In addition, while expenditure limitation laws are aimed at limiting the growth in spending, many such laws place restraints on general fund surpluses. California's expenditure limitation law, which is commonly known as Proposition 13, requires one-half of any general fund surplus to be returned to citizens. Clearly if California's decision-makers are committed to saving, doing so only using the general fund may not be feasible. Thus, states with such general fund restrictions should be more likely to adopt budget stabilization funds than states without such restrictions, ceteris paribus. Binary variables are included in the empirical model to control for the existence of tax and expenditure limitation laws. The dates of adoption for tax and expenditure limitation laws were obtained from the National Conference of State Legislature's (NCSL) State Tax and Expenditure Limits, 1998.

\subsubsection{Revenue Issues}

In addition to balanced budget rules and tax and expenditure limitation laws, a state's ability to generate revenue will also be dependent on its existing tax structure and tax collections. The Advisory Commission on Intergovernmental Relations (ACIR) computes an index of each state's tax effort, which is the ratio of actual state tax collections to the

\footnotetext{
${ }^{34}$ For evidence that tax and expenditure limitation laws are not binding see Abrams and Dugan (1986), Cox and Lowery (1990), and Bails (1990). Evidence of their effectiveness can be found in Dugan (1988), Stansel (1994), Ruben (1995), and Elder (1992).
} 
state's tax capacity. ${ }^{35} \mathrm{~A}$ tax index greater than 100 (which is the base) signifies that a state's ability to generate additional revenue through taxation may be reaching its limit. All other factors constant, states with higher ACIR tax efforts should find it more difficult to increase tax revenue in the event of a revenue shortfall, and thus may be more likely to adopt a budget stabilization fund. Since the ACIR's tax effort index is not computed prior to 1967 and is also not computed annually, each state's average tax effort is computed based on the ACIR's reported figures that range from 1967 to 1988.

Aside from fiscal and political motives, the fact that many states adopted budget stabilization funds around the time of the recession of the early 1980s is indicative that fiscal stress played a role in many states' decisions to adopt stabilization funds, and thus must also be explored as a potential determinant. While many factors may contribute to state fiscal stress, Holcombe and Sobel (1997) have convincingly argued that the primary cause of state fiscal stress is the short-run variability of state revenue streams. During economic downturns, tax bases tend to contract which adversely impacts state revenue streams. Thus, a measure of the short-run correlation between a state's revenue and the state's business cycle will provide a measure of how a state's revenue stream will respond to an economic downturn. ${ }^{36}$

To obtain an measure of each state's short-run revenue variability, I follow the methodology of Sobel and Holcombe (1996b). Using a twenty-year rolling sample, the

35 The ACIR determines the state's tax capacity based on the state's tax revenue if taxes were imposed on twenty-six commonly used tax bases. For more information see ACIR (1990), 1988 State Fiscal Capacity and Effort.

${ }^{36}$ For a discussion regarding the difference between the long-run and short-run variability of revenue streams, see Sobel and Holcombe (1996b). 
following equation is estimated for each state:

$$
\ln \Delta R_{i}=\alpha+\beta \ln \Delta P I_{i}+\varepsilon_{i}
$$

where $R_{i}$ is the real general fund revenue of state $i$ and $P I_{i}$ is the total real personal income of state $i$. The estimate of $\beta$, which Sobel and Holcombe (1996b) refer to as the short-run elasticity, is a measure of the responsiveness (cyclical variability) of state revenue to changes in personal income. ${ }^{37}$ If the estimate of $\beta$ is greater than unity, then the state's general fund revenue varies more than personal income, indicating that the state's revenue growth should slow more than the state's economy during a contraction. Thus, one would expect a state with more variable revenue to be more likely to adopt a stabilization fund, ceteris paribus.

While the responsiveness of a state's revenue stream to changes in the state's business cycle is an important indicator of the potential revenue shortfall a state may face during an economic downturn, cyclical variability in a state's economy is also an important variability measure. For example, a state whose economy does not vary much in response to shocks, but whose revenue varies highly with changes in the state's economy, may be more likely to adopt a stabilization fund than a state whose economy varies highly in response to a shock, but whose revenue does not much vary much with

\footnotetext{
${ }^{37}$ Since a consistent series for state personal income is not available prior to 1929, each state's estimate of $\beta$ for 1945, 1946, 1947, 1948, and 1949 were obtained by estimating equation (4.5) over the period from 1929 to the each respective year. Beginning in 1950 and continuing until 1996, the estimates were obtained from the sample period 19301950 , updated by one period each year. General fund revenue for each state were obtained from the Statistical Abstract of the United States, state personal income data were obtained from the Bureau of Economic Analysis, and all nominal values were deflated using the CPI (1992=100).
} 
changes in the state's business cycle. Thus, to account for cyclical variability in a state's economy, a twenty-year moving sample of each state's standard deviation of the growth in real personal income is included in the empirical model. ${ }^{38}$ All other factors constant, one would expect states with more variable economies to be more likely to adopt a budget stabilization fund.

An additional important indicator of variability for states is the variability of revenue over the business cycle that is caused by non-cyclical factors. As Sobel and Holcombe (1996b) note, the estimated standard error of the short-run elasticity of revenue obtained from equation (4.5), provides a measure of the variability of a state's revenue over the business cycle due to non-cyclical factors. While the estimate of $\beta$ from equation (4.5) provides information regarding how a state's revenue stream changes as a result of the cyclical variability in the state's economy, the standard error of $\beta$ is a measure of the predictability of the cyclical variability of a state's revenue. To control for the variability in revenue generated by non-cyclical factors, the estimated standard errors of each state's short-run elasticity estimate is included as a regressor in the model. States whose cyclical variability of revenue is less predictable, and thus have larger estimated standard errors of their short-run elasticity of revenue, should have a higher demand for precautionary balances and hence be more likely to adopt a budget stabilization, ceteris paribus.

\footnotetext{
38 The variance of states' real growth in personal income was also employed in the panel probit model and there was no significant change in the results. Since a consistent series for state personal income is not available prior to 1929, each state's standard deviation of real personal income growth for 1945, 1946, 1947, 1948, and 1949 were obtained by computing the standard deviation using data over the period from 1929 to the each respective year. Beginning in 1950 and continuing until 1996, the estimates were obtained from the sample period 1930-1950, updated by one period each year.
} 
While the variability measures capture the cyclical variation in state revenue, the cyclical variation in the state's economy, and the non-cyclical variation in revenue, none of these measures will capture the actual severity states experienced during contractions. For example, two states that have the same cyclical variation (as measured by the standard deviation of their growth in personal income) in their economy could have substantially different recession experiences. During a recession, one state's real personal income growth could fluctuate highly, but be positive, while another state's real personal income growth could fluctuate the same amount but be negative. In each case the cyclical variability measure will be the same, but the state which experienced negative growth in real personal income suffered more during the recession than did the state experiencing positive growth. Thus to account for the severity of recessions, a five-year moving average of the growth in states' real personal incomes is included as a regressor. A fiveyear moving average was selected because states' decision-makers may be making choices influenced by contractions for several years following the contraction. A priori, one would expect that if the severity of a recession has influenced states' choice to adopt a budget stabilization fund, then states will be more likely to adopt a budget stabilization fund when the state's average real personal income growth is lower, all other factors constant. Thus, a negative coefficient estimate for this variable would indicate that states are more likely to adopt budget stabilization during, or just following, contractionary periods. 


\subsubsection{Fiscal Preferences}

Decision-makers' fiscal discipline and commitment to saving may also influence their decision to adopt a budget stabilization fund. For example, states that are large savers and are committed to saving may adopt a budget stabilization fund as a way to ensure the state continues saving. On the other hand, states whose decision-makers have not been actively saving may see a budget stabilization fund as a means to instill fiscal discipline and commit them to saving. Since Bohn and Inman (1996) have found that state per capita savings is highly correlated with the fiscal constraints states face, simply including per capita savings in the model would likely induce collinearity problems. Thus, to proxy each state's fiscal discipline, a fixed time-effects panel model is estimated in which states' per capita savings is regressed on state balanced budget rules, revenue and expenditure limitation laws, debt restrictions, and the variability measures described in the preceding paragraphs. ${ }^{39}$ The difference between each state's actual saving and predicted saving is then included in the panel probit model as a proxy for the state's fiscal discipline. A negative coefficient estimate for this variable would indicate that a state which is currently saving less than what their fiscal constraints would predict is more likely to adopt a budget stabilization, ceteris paribus. On the other hand, a positive coefficient estimate would imply that a state which is currently saving more than their fiscal

\footnotetext{
39 The debt categories included in the fixed effects panel model are from Kiewiet and Szakaly (1996). Since Kiewiet and Szakaly (1996) found state debt restrictions to be correlated with the level of state debt, debt restrictions are not included in the panel probit model to avoid collinearity problems with the ratio of debt to personal income. However, estimates were completed using debt restrictions and the ratio of debt to personal income and none of the coefficients of the debt restrictions were statistically different from zero.
} 
constraints would predict is more likely to adopt a budget stabilization fund, all other factors constant.

The final variable included in the panel probit model is a proxy for the state's credit worthiness. State bond ratings are tightly linked to the state's credit worthiness, and bond ratings are a central component of public sector financing. If a state's bond ratings are lowered, then capital investment costs for the state rise. A state's decision-makers may see budget stabilization funds as a way to improve the state's bond rating, or at least maintain current ratings. As Oregon's Director of Debt Management has noted, "bond rating companies look to see if there are revenue balances or reserves, which could be called upon in the event of revenue shortfalls. The ending general fund balance and a stabilization fund are the most common forms of available monies to meet an issuer's contingencies." ${ }^{40}$ Given Bayoumi et al.'s (1995) finding that the ratio of debt to personal income is negatively correlated with state bond yields, each state's ratio of real gross debt to personal income is included as a proxy for the state's credit worthiness. A positive coefficient estimate for this variable would indicate that states that are likely to have good credit ratings are more likely to adopt a budget stabilization, all other factors constant. In contrast, a negative coefficient estimate for this variable would indicate that state's which are likely to have lower credit ratings are more likely to adopt a stabilization fund, ceteris paribus.

\footnotetext{
${ }^{40}$ From a "Testimony in Support of a Budget Stabilization Fund," given by Chuck Smith to Oregon's Senate Budget Committee. The entire testimony is available from URL http://www.ost.state.or.us/testimony/onsfund.htm [Accessed 20 September 1999].
} 


\subsection{Empirical Results}

The maximum likelihood coefficient and marginal coefficient estimates of the panel probit model are presented in Table 4.2 and provide some interesting insights. First, stringent balanced budget rules and the enforcement of fiscal rules (elected supreme court) are uncorrelated with states' decisions to adopt budget stabilization funds.

However, when the state's legislature is merely required to adopt a balanced budget at the beginning of the fiscal year, the state is significantly less likely to adopt a stabilization fund. This may be due to the fact that when deficit financing is permitted, the state's decision-makers are not forced to engage in the politically costly actions of reducing expenditures and/or increasing taxes.

From the variability measures, only the variability of states' revenue due to noncyclical factors is correlated with adopting a budget stabilization fund. Thus, while the cyclical variability in states' economies and the cyclical variability of revenue over the business cycle are uncorrelated with states' decisions, states which have more noncyclical variability in their revenue streams over the business cycle (as measured by the standard error of the state's short-run elasticity of revenue with respect to the state's business cycle) are more likely to adopt stabilization funds than states with more predictable variability, other factors constant. In fact, the standard error of states' shortrun elasticity of revenue has the largest marginal effect on states' adoption choices. A one unit increase in a state's standard error (a reduction in the predictability of cyclical variation) increases the probability the state will adopt a budget stabilization fund by nearly 3 percent, ceteris paribus. 
Table 4.2 - Determinants of State Budget Stabilization Fund Adoption

\begin{tabular}{|c|c|c|}
\hline Variables & Coefficient estimates & $\begin{array}{c}\text { Marginal coefficient } \\
\text { estimates }\end{array}$ \\
\hline Constant & $\begin{array}{l}-1.565^{*} \\
(0.858)\end{array}$ & $\begin{array}{l}-3.680 \\
(2.263)\end{array}$ \\
\hline Fiscal Constraints & & \\
\hline Governor submits balanced budget & $\begin{array}{l}-0.170 \\
(0.351)\end{array}$ & $\begin{array}{c}-0.401 \\
(0.828)\end{array}$ \\
\hline Legislature adopts balanced budget & $\begin{array}{c}-0.863^{* * * *} \\
(0.313)\end{array}$ & $\begin{array}{c}-2.029^{* * * *} \\
(0.769)\end{array}$ \\
\hline Deficit corrected in upcoming fiscal year & $\begin{array}{c}0.365 \\
(0.243)\end{array}$ & $\begin{array}{c}0.859 \\
(0.594)\end{array}$ \\
\hline Deficit not permitted in next fiscal year & $\begin{array}{l}-0.431 \\
(0.323)\end{array}$ & $\begin{array}{c}-1.015 \\
(0.757)\end{array}$ \\
\hline Deficit not permitted in next budget cycle & $\begin{array}{l}-0.369 \\
(0.294)\end{array}$ & $\begin{array}{l}-0.868 \\
(0.691)\end{array}$ \\
\hline ACIR tax effort & $\begin{array}{c}-0.012 \\
(0.008)\end{array}$ & $\begin{array}{l}-0.030 \\
(0.019)\end{array}$ \\
\hline Elected supreme court & $\begin{array}{l}-0.066 \\
(0.181)\end{array}$ & $\begin{array}{l}-0.155 \\
(0.425)\end{array}$ \\
\hline Revenue limitation law & $\begin{array}{l}0.851^{* *} \\
(0.374)\end{array}$ & $\begin{array}{l}2.001^{* * *} \\
(0.993)\end{array}$ \\
\hline Expenditure limitation law & $\begin{array}{l}1.081^{* * *} \\
(0.301)\end{array}$ & $\begin{array}{c}2.543^{* * * *} \\
(0.822)\end{array}$ \\
\hline Fiscal Preferences & & \\
\hline Difference between actual and predicted savings & $\begin{array}{l}0.002^{* * *} \\
(0.0007)\end{array}$ & $\begin{array}{c}0.005^{* * *} \\
(0.002)\end{array}$ \\
\hline Ratio of real gross debt to real personal income & $\begin{array}{c}-1.135^{* * *} \\
(0.484)\end{array}$ & $\begin{array}{c}-2.670^{* * *} \\
(1.040)\end{array}$ \\
\hline Variability Measures & & \\
\hline Std. error of short-run elasticity of total revenue & $\begin{array}{l}1.241^{* *} \\
(0.492)\end{array}$ & $\begin{array}{l}2.917^{* *} \\
(1.287)\end{array}$ \\
\hline Std. deviation of real personal income growth & $\begin{array}{l}-0.081 \\
(0.074)\end{array}$ & $\begin{array}{l}-0.192 \\
(0.171)\end{array}$ \\
\hline $\begin{array}{l}\text { Short-run elasticity of total revenue with respect to state } \\
\text { business cycle }\end{array}$ & $\begin{array}{c}0.113 \\
(0.186)\end{array}$ & $\begin{array}{c}0.267 \\
(0.440)\end{array}$ \\
\hline 5-year moving average of real PI growth & $\begin{array}{l}-0.071^{*} \\
(0.036)\end{array}$ & $\begin{array}{l}-0.167^{*} \\
(0.087)\end{array}$ \\
\hline Political Factors & & \\
\hline Number of seats in lower house & $\begin{array}{c}-0.0001 \\
(0.001)\end{array}$ & $\begin{array}{c}-0.0002 \\
(0.003)\end{array}$ \\
\hline Number of seats in upper house & $\begin{array}{l}0.022^{* * *} \\
(0.010)\end{array}$ & $\begin{array}{l}0.052^{* *} \\
(0.025)\end{array}$ \\
\hline $\begin{array}{l}\text { Total number of changes in controlling parties over } \\
\text { previous twenty years }\end{array}$ & $\begin{array}{l}0.040^{*} \\
(0.022)\end{array}$ & $\begin{array}{l}0.095^{*} \\
(0.056)\end{array}$ \\
\hline Sample size & \multicolumn{2}{|c|}{1849} \\
\hline Log-likelihood & \multicolumn{2}{|c|}{-159.06} \\
\hline Likelihood Ratio Index & \multicolumn{2}{|c|}{0.17} \\
\hline
\end{tabular}

Notes: Standard errors in parentheses. Significance levels are as follows: "denotes significance at the 1 percent level, ${ }^{* * *}$ at the 5 percent level, and ${ }^{*}$ at the 10 percent level. Marginal coefficients and their standard errors are reported times 100. 
In addition, the measure of the severity of recessions, the five-year moving average of states' real personal income growth, is negative and significant at the 10 percent level. This is consistent with the notion that recessions have played a role in states' choices. The marginal coefficient indicates that a 1 percent reduction in a state's five-year average growth rate in personal income increases the likelihood that a state will adopt a stabilization fund by .167 percent. Despite the small magnitude of the estimated marginal coefficient, this results lends evidence in support of Gold (1983) and Sobel and Holcombe (1996a), who claim that many states which adopted stabilization funds, especially in the early 1980s did so as a result of the 1980-1982 recession.

Further, the coefficient of the total number of changes in the controlling political party of states' houses over the previous twenty years is statistically significant at the 10 percent level. This result is consistent with the notion that decision-makers in states which have experienced more long-term political instability have more to gain from saving and thus may be more likely to adopt a budget stabilization fund to reduce the common pool problem. In addition, the coefficient for the number of seats in the state's upper house is significant at the 5 percent level. Although the magnitude of the marginal coefficient for the number of seats in the upper house is rather small (.052), this finding is consistent with a political prisoner's dilemma motive for adopting a stabilization fund.

Aside from possible political motives, the existence of both tax and expenditure limitation laws significantly increases the probability that a state will adopt a budget stabilization fund. A tax limitation law in place increases the probability that a state will adopt a budget stabilization fund by 2 percent, while the existence of an expenditure limitation law increases the probability by 2.5 percent. The finding that expenditure 
limitation laws significantly increases the probability that a state adopts a stabilization fund suggests that states' decision-makers have attempted to circumvent the 'tax revolt' of the 1970s and 1980s by finding alternate methods to maintain reserves, which may explain many state's adoption choices in the mid-1980s. This result indicates that while the recession of the early 1980 s did in fact play a role in states' choices, the recession alone is not likely to explain the entire growth in stabilization fund usage which occurred during the 1980 s.

The empirical results are also consistent with the notion that states in good fiscal health are more likely to adopt budget stabilization funds than states in poor fiscal health, all other factors constant. In fact, the results show that states are more likely to adopt a stabilization fund when their current savings is larger than predicted based upon their existing fiscal constraints. Moreover, states are more likely to adopt a budget stabilization fund when their ratio of real gross debt to personal income is low, which is likely to coincide with a high credit rating. Thus, there is some evidence that states that are committed to saving and maintaining the state's credit worthiness see budget stabilization funds as a way to maintain their fiscal health.

To summarize the empirical results, the panel probit estimates yield evidence that is consistent with the claim that budget stabilization funds are more likely to be adopted as a means of saving in states which are committed to fiscal discipline, as measured by the state's ratio of real gross debt to personal income and the difference between actual savings and predicted savings based on the state's fiscal constraints. Budget stabilization funds are also more likely to be adopted in years during, or just following, an economic contraction. In addition, existing tax and expenditure limitation laws increases the 
probability that a state will adopt a budget stabilization fund. This suggests that some states may have attempted to circumvent the fiscal constraints of the tax revolt era by using stabilization funds rather than the state's general fund as a vehicle for saving. In addition, the empirical results also illustrate that states with greater unpredictability in the cyclical variability of their revenue streams are more likely to adopt budget stabilization funds. Finally, the results are consistent with the notion that decision-makers in states which have witnessed high politically instability adopted budget stabilization funds as a method to reduce political manipulation of savings resulting from the common pool problem.

\subsection{Conclusion}

While budget stabilization funds are a popular vehicle of saving for state governments, the rise in fund usage has been a relatively recent phenomenon. Of the 44 states that currently utilize a budget stabilization fund in conjunction with the state's general fund for securing precautionary funds, more than two-thirds did not begin utilizing a stabilization fund until after 1980.

While previous research investigating the effectiveness of budget stabilization funds has generally indicated that states have benefited from their presence, an investigation of the factors influencing states' decisions to adopt budget stabilization funds has thus far been untouched by the literature. Using unpublished data obtained from each state on the year of stabilization fund adoption, this chapter examines the role that state economic, political, fiscal preferences, and fiscal conditions played in states' 
decision to adopt stabilization funds by estimating a panel probit model over the period from 1945-1996.

The empirical results provide some evidence that states adopted budget stabilization funds for a variety of reasons. First, the results provide evidence in support of Gold (1983) and Sobel and Holcombe (1996a), who claim that the dramatic increase in stabilization fund usage during the 1980s was due largely to the 1980-1982 recession. However, the estimates also reveal that not all of the adoptions that occurred during the 1980s are likely to be a direct result of the recession. The existence of tax and expenditure limitation laws, the majority of which were adopted between 1979 and 1985 , also significantly influenced states' adoption choices. Thus, there is evidence that at least some states adopted budget stabilization funds during the 1980s as a means to lessen the sting of tax and expenditure limitation laws rather than in response to the recession. This finding is likely due to the fact that stabilization funds provide states' decision-makers with an acceptable method to circumvent some fiscal mandates.

In addition, the results indicate that the predictability of the cyclical variability of a state's revenue over the business cycle, rather than cyclical variability in the state's economy or the cyclical variability in the state's revenue, is a principle factor affecting states' choices. Thus, states whose revenue streams are less predictable over the business cycle, regardless of how cyclical, are more likely to adopt stabilization funds, all other factors constant.

Furthermore, the fact that the number of seats in a state's upper house is positively correlated with adopting a stabilization fund is consistent with a political prisoner's dilemma motive. Since legislators may individually prefer to spend any surplus, even 
though they may collectively be better off by saving the funds, they may opt to save in a stabilization fund since stabilization funds have the potential to require saving.

Next, states are more likely to adopt budget stabilization funds when their ratio of real gross debt to personal income is small, and their current level of savings is greater than the quantity that would be predicted given their fiscal constraints, ceteris paribus. These findings are consistent with the notion that states which are committed to sound fiscal policies and maintaining the state's credit worthiness are more likely to adopt stabilization funds than states which have lower credit ratings and less commitment to fiscal discipline.

Finally, the empirical results provide evidence consistent with the hypothesis that decision-makers opted to establish stabilization funds as a means to reduce political manipulation resulting from the common pool problem. 


\section{Chapter 5}

\section{Are State Budget Stabilization Funds only the Illusion of Savings?}

\subsection{Introduction}

"Prudent financial management requires not only paying today's bills in a timely manner, but also providing for an uncertain future. For a state government, that uncertainty can include more than economic downturns. It also includes the potential for natural disasters, cutbacks in federal support for vital state programs, and adverse court decisions. Although Illinois is in its best financial shape since 1989 , it is still unprepared for uncertainty. The state's lack of reserves could mean that it will again suffer severe fiscal distress in the future." - "Saving for a Rainy Day," State of Illinois Comptroller's Fiscal Focus, February/March 1999.

State governments consider reserve balances to be an integral component of fiscal management and the number of states utilizing budget stabilization funds as a means to maintain fungible monies has increased dramatically in the last two decades. While states continue to rely on expenditure reductions and discretionary tax increases to mitigate periods of fiscal stress, states have become increasingly dependent on accumulated reserves (or savings) as a short-run policy tool. According to a 1993 General Accounting Office survey of states, of the 32 states which reported experiencing a fiscal deficit, about one-third of the aggregate deficit was corrected using accumulated balances held in budget stabilization funds.

The fiscal institutions facing many states can make raising revenue difficult in the short-run. Along with balanced budget rules, many states also face expenditure and tax limitation laws which restrict revenue and spending growth, and debt restrictions which limit the short-term and long-term general obligation debt a state may issue, all of which 
impact states' policy options in the event of a revenue shortfall. ${ }^{41}$ However, since most states face balanced budget laws are stock rather than flow in nature, current expenditures for these states may exceed current revenue as long as the state has sufficient reserves to match the revenue shortfall. Consequently, states have long engaged in the practice of saving during expansions for use during periods of depressed revenue growth, but the dramatic increase in budget stabilization fund usage has been a significant change in states' attempts to secure precautionary funds.

In general, when states run surpluses in the general fund, states with budget stabilization funds (hereafter BSFs) deposit a fraction of that surplus in the state's stabilization fund and retain the remainder in the general fund. From an accounting standpoint, surpluses in states' general funds are non-accumulating since they are automatically treated as revenue in the next fiscal year. In contrast, BSF funds are accumulating because they are not automatically considered a component of revenue in the next fiscal year. Thus, the total fungible reserves available to a state at the end of any given fiscal year is the sum of the state's BSF balance and general fund surplus, while the contribution to savings in that particular fiscal year is the sum of the change in the state's general fund surplus plus the change in the state's BSF balance from the previous year.

States' abilities to mitigate periods of fiscal stress using savings are dependent on the total balances available from the state's general fund and BSF. From an economic

\footnotetext{
${ }^{41}$ For evidence that stringent balanced budget rules have real effects see Levinson (1998), Alesina and Bayoumi (1996), Poterba (1996, 1995, 1994), Bohn and Inman (1996), Alt and Lowry (1994), and ACIR (1987). See Poterba (1996), Rueben (1995), and Elder (1992) for an examination of state tax and expenditure limitation laws; see von Hagen (1991), Bunch (1991), and Kiewiet and Szakaly (1996) regarding state debt limitations. For a review of state fiscal institutions in general see Knight and Levinson (1999b) and Bohn and Inman (1996).
} 
standpoint it does not matter whether states retain balances only in the general fund, only in a BSF, or both, since general fund surpluses and BSF balances earn the same market return and are subject to the same economic risks (inflation risk and systematic risk). There are however potential advantages to holding funds in a stabilization fund as opposed to the general fund. First, states whose decision-makers do not possess the fiscal discipline necessary to retain surplus balances for future use may adopt stabilization funds that require monies to be placed into the BSF. This can be accomplished by requiring surplus balances in the general fund to be transferred to the BSF or by requiring deposits on an annual basis. For this to enhance a state's fiscal health, it is necessary that legislators retain the monies placed in the BSF until they are truly needed.

Second, without contributing more to savings in a given year, states may structure BSFs in such a way as to retain the funds they do save longer. Since, in principle, a BSF which is structured identically to the states general fund should be a perfect substitute for general fund balances, states can increase their total balances available at any given time if funds placed in the BSF are retained longer than surplus balances in the general fund. This can be accomplished by opting for more stringent withdrawal rules than exist in the general fund (such as a supermajority voting rule) making it more difficult to spend existing BSF balances, and states may also restrict the services for which BSF balances can be used.

Next, states facing flow balanced budget constraints (such as Michigan) and states facing restrictions on the size of general fund surpluses (such as California) may use a budget stabilization fund as means to circumvent such restrictions and maintain precautionary balances. Finally, adopting a budget stabilization fund to be used in 
conjunction with the general fund may ignite a sense of fiscal awareness in states' decision-makers causing them to be more financially prudent regardless of the fund's structure. Hence, states use of budget stabilization funds have the potential to alter the savings behavior of states by increasing the amount of money states save in a given year and/or increasing the rate at which states retain the funds that they do save.

While budget stabilization funds can be potentially beneficial for states, if the structure of a state's budget stabilization fund closely resembles the state's general fund, which means that funds are deposited and withdrawn at the discretion of the legislature for any purpose, utilizing a budget stabilization fund may have no noticeable impact on the state's savings behavior. If a state's legislature does not possess the fiscal discipline to retain monies in the state's general fund and BSF balances can be appropriated as easily as general fund balances, it is difficult to imagine that the state's legislature will save any more, or retain funds longer, simply because they have multiple vehicles for saving.

Although research investigating the impact that budget stabilization funds have had on states' fiscal behavior is rather limited, this research does suggest that stabilization funds have had a favorable impact on states' fiscal health. Over the period from 19691995, Levinson (1998) finds that states with budget stabilization funds experienced less volatile business cycles than states that do not possess stabilization funds. Similarly, in a paper examining the impact that stabilization funds had on states' ability to cope with fiscal stress during the 1990-1991 recession, Sobel and Holcombe (1996a) find that states with budget stabilization funds experienced fewer reductions in expenditures below their long-run growth rate than states without stabilization funds, and that states whose funds had explicit deposit requirements experienced significantly less fiscal stress than states 
whose BSFs did not contain such requirements. More recently, Knight and Levinson (1999a), using a panel of data from 1984-1997, find that states with BSFs save more than states without BSFs and that states' total balances are higher after adopting a BSF. In addition, Knight and Levinson find that total balances respond one-for-one with increases in stabilization fund balances, suggesting that budget stabilization funds and states' general funds are not perfect substitutes.

Using data on the fiscal-year-end balance of each state's BSF from inception, this chapter examines the impact of each state's budget stabilization fund on the state's savings behavior over their entire history of BSF usage. A transfer function model is estimated for each state to obtain estimates of the change in each state's average rate of saving and average total balances between the state's pre-BSF savings behavior and BSF savings behavior. This approach allows me to formally examine the substitutability or complementarity of BSFs and general fund surpluses. Second, using the estimated behavioral changes from the transfer function models, I examine the extent to which the structure of stabilization funds has influenced their effectiveness by regressing the estimated change in states' average rate of savings and average total balances on fund characteristics.

The empirical results illustrate that one-third of states have experienced a significant change in their savings behavior after enacting a budget stabilization fund, suggesting that for a majority of states budget stabilization funds have been perfectly substitutable with states' general funds. The states that have benefited witnessed a significant increase in their total balances, but not their savings rate. This indicates that the states that are saving more after enacting stabilization funds are doing so by retaining 
balances longer, not from contributing more to savings. Most important, the estimates reveal that states can most benefit from a BSF if they are required to deposit funds and restrict how the funds may be spent. Thus the results do not indicate that budget stabilization funds are ineffective, rather they indicate that the more stringent a state's budget stabilization is relative to the state's general fund, the more likely the state is to save more after utilizing a budget stabilization fund.

The remainder of the chapter proceeds as follows: Section 5.2 discusses budget stabilization funds and the role they have in states' saving, Section 5.3 outlines the empirical methodology used to estimate the change in states' savings behavior and presents the results of such estimation, Section 5,4 examines the role BSF characteristics play in the behavioral changes experienced by states after enacting a BSF, and Section 5.5 concludes the chapter.

\subsection{The Role of Budget Stabilization Funds in States' Saving}

Although the goal of BSFs to provide a stock of fungible balances is common to all states, there is wide variation across states in the structure of stabilization funds. The most profound differences in the structure of stabilization funds occur in the methods for depositing funds, withdrawing funds, and the maximum size of the fund. This information, along with the adoption date and first deposit date, are included in Table 5.1.

As is evident, a majority of states deposit funds into their BSF only in the event of a general fund surplus and withdraw funds at the discretion of the legislature. However, several states, whose funds would be classified as 'stringent funds,' use statutory formulae 
Table 5.1 - Structure of State Budget Stabilization Funds

\begin{tabular}{|c|c|c|c|c|c|c|}
\hline State & Fund Name & $\begin{array}{c}\text { Year } \\
\text { Adopted } \\
\end{array}$ & $\begin{array}{c}\text { First } \\
\text { Balance } \\
\end{array}$ & Deposit Rule & Withdrawal Rule & Maximum Fund Size \\
\hline $\mathrm{AK}$ & Budget Reserve Fund & 1986 & 1991 & Appropriation & Appropriation & No limit \\
\hline $\mathrm{AK}$ & Constitutional Budget Reserve & 1990 & 1991 & $\begin{array}{l}\text { Mineral revenues in } \\
\text { excess of permanent } \\
\text { fund }^{*}\end{array}$ & $3 / 4$ of legislature & No limit \\
\hline $\mathrm{AL}$ & -- & -- & -- & -- & -- & -- \\
\hline $\mathrm{AZ}$ & Budget Stabilization Fund & 1990 & 1994 & Statutory formula & Statutory formula & Rolling cap \\
\hline AR & -- & -- & -- & -- & -- & -- \\
\hline $\mathrm{CA}$ & $\begin{array}{l}\text { Special Fund for Economic } \\
\text { Uncertainties }\end{array}$ & 1976 & 1977 & General Fund Surplus & Revenue Shortfall & No limit \\
\hline $\mathrm{CO}$ & $\begin{array}{l}\text { Required Fund Balance } \\
\text { (non-accumulating) }\end{array}$ & 1982 & 1982 & $4 \%$ of revenue forecast & Revenue shortfall & $4 \%$ of revenue forecast \\
\hline CT & Budget Reserve Fund & 1979 & 1984 & $\begin{array}{l}\text { Not less than } 10 \% \text { of } \\
\text { General Fund surplus }\end{array}$ & $\begin{array}{c}\text { Governor request and 2/3 } \\
\text { legislative approval }\end{array}$ & $\begin{array}{c}5 \% \text { of current net General } \\
\text { Fund appropriations }\end{array}$ \\
\hline $\mathrm{DE}$ & Budget Reserve Account & 1979 & 1979 & General Fund surplus & $3 / 5$ of legislature & $\begin{array}{c}5 \% \text { of General Fund } \\
\text { revenue }\end{array}$ \\
\hline $\mathrm{FL}$ & Working Capital Fund & 1959 & 1965 & General Fund surplus & Revenue shortfall & $\begin{array}{l}10 \% \text { of previous year's } \\
\text { General Fund revenue }\end{array}$ \\
\hline FL & Budget Stabilization Fund & 1992 & 1995 & $\begin{array}{l}\text { Required appropriation } \\
\text { equal to } 5 \% \text { of last year's } \\
\text { general fund revenue }\end{array}$ & Revenue shortfall & $\begin{array}{l}10 \% \text { of previous year's } \\
\text { General Fund revenue }\end{array}$ \\
\hline GA & Revenue Shortfall Reserve & 1976 & 1976 & $\begin{array}{c}3 \% \text { of General Fund } \\
\text { surplus }\end{array}$ & Appropriation & No limit \\
\hline $\mathrm{HI}$ & -- & -- & -- & -- & -- & -- \\
\hline ID & Budget Stabilization Fund & 1984 & 1984 & Appropriation & Appropriation & No limit \\
\hline IL & -- & -- & -- & -- & -- & -- \\
\hline IN & $\begin{array}{l}\text { Counter-Cyclical Revenue and } \\
\text { Economic Stabilization Fund }\end{array}$ & 1982 & 1985 & Statutory formula & Statutory formula & $\begin{array}{c}7 \% \text { of General Fund } \\
\text { revenue }\end{array}$ \\
\hline IA & Cash Reserve Fund & 1984 & 1994 & Appropriation & $\begin{array}{c}\text { Single-bill appropriation } \\
\text { not to cause fund to fall } \\
\text { below } 3 \% \text { of revenue } \\
\text { estimate for that year }\end{array}$ & Statutory formula \\
\hline IA & Economic Emergency Fund & 1984 & 1992 & Appropriation & Appropriation & $\begin{array}{l}5 \% \text { of revenue estimate } \\
\text { for that fiscal year }\end{array}$ \\
\hline
\end{tabular}




\begin{tabular}{|c|c|c|c|c|c|c|}
\hline State & Fund Name & $\begin{array}{c}\text { Year } \\
\text { Adopted }\end{array}$ & $\begin{array}{c}\text { First } \\
\text { Balance }\end{array}$ & Deposit Rule & Withdrawal Rule & Maximum Fund Size \\
\hline KY & $\begin{array}{c}\text { Budget Reserve Trust Fund } \\
\text { Account }\end{array}$ & 1983 & 1983 & $\begin{array}{c}\text { General Fund surplus and } \\
\text { appropriation }\end{array}$ & Appropriation & $\begin{array}{l}5 \% \text { of General Fund } \\
\text { revenue }\end{array}$ \\
\hline $\mathrm{KS}$ & General Fund Ending Balance & 1993 & 1993 & $\begin{array}{l}7.5 \% \text { of General Fund } \\
\text { expenditures that year }\end{array}$ & Appropriation & No limit \\
\hline LA & $\begin{array}{l}\text { Revenue Stabilization and } \\
\text { Mineral Trust Fund }\end{array}$ & 1990 & -- & $\begin{array}{l}\text { Revenues exceeding } \$ 750 \\
\text { million from minerals }\end{array}$ & Appropriation & No limit \\
\hline $\mathrm{ME}$ & Rainy Day Fund & 1985 & 1985 & $\begin{array}{l}1 / 2 \text { of General Fund } \\
\text { surplus }\end{array}$ & Appropriation & $\begin{array}{c}5 \% \text { of General Fund } \\
\text { revenue }\end{array}$ \\
\hline MD & Revenue Stabilization Account & 1985 & 1986 & $\begin{array}{l}\text { Required appropriation } \\
\text { equal to } 5 \% \text { of estimated } \\
\text { GF revenue that year }\end{array}$ & Appropriation & $\begin{array}{c}\text { Lessor of } 5 \% \text { of General } \\
\text { Fund revenue or } \$ 50 \\
\text { million }\end{array}$ \\
\hline MA & $\begin{array}{c}\text { Commonwealth Stabilization } \\
\text { Fund }\end{array}$ & 1985 & 1986 & General Fund surplus & Appropriation & $5 \%$ of budgeted revenue \\
\hline MI & $\begin{array}{l}\text { Countercyclical Budget and } \\
\text { Economic Stabilization Fund }\end{array}$ & 1977 & 1978 & Statutory formula & Statutory Formula & $\begin{array}{l}25 \% \text { of General Fund } \\
\text { revenue }\end{array}$ \\
\hline $\mathrm{MN}$ & Budget Reserve Account & 1981 & 1984 & Appropriation & Appropriation & $\$ 522$ million \\
\hline $\mathrm{MN}$ & Cash Flow Account & 1995 & 1996 & Required appropriation & Appropriation & $\$ 350$ million \\
\hline MS & $\begin{array}{c}\text { Working Cash Stabilization } \\
\text { Reserve Fund }\end{array}$ & 1982 & 1983 & Appropriation & Appropriation & $\begin{array}{c}71 / 2 \% \text { of General Fund } \\
\text { revenue }\end{array}$ \\
\hline MO & Budget Stabilization Fund & 1992 & 1992 & Appropriation & Appropriation & $\begin{array}{l}5 \% \text { of General Fund } \\
\text { Revenue }\end{array}$ \\
\hline MT & -- & -- & -- & -- & -- & - \\
\hline $\mathrm{NC}$ & Savings Reserve Account & 1991 & 1991 & General Fund surplus & Appropriation & $\begin{array}{l}5 \% \text { of General Fund } \\
\text { revenue }\end{array}$ \\
\hline ND & Budget Stabilization Fund & 1987 & 1990 & $\begin{array}{l}\text { General Fund surplus in } \\
\text { excess of } \$ 40 \text { million }\end{array}$ & $\begin{array}{c}\text { Revenue must be } 21 / 2 \% \\
\text { below forecast }\end{array}$ & No limit \\
\hline $\mathrm{NE}$ & Cash Reserve Fund & 1983 & 1984 & General Fund surplus & Revenue shortfall & No limit \\
\hline $\mathrm{NH}$ & $\begin{array}{c}\text { Revenue Stabilization Reserve } \\
\text { Account }\end{array}$ & 1987 & 1987 & General Fund surplus & Revenue shortfall & $\begin{array}{c}5 \% \text { of General Fund } \\
\text { revenue }\end{array}$ \\
\hline NJ & Surplus Revenue Fund & 1990 & 1993 & $\begin{array}{c}50 \% \text { of General fund } \\
\text { surplus }\end{array}$ & Revenue shortfall & $\begin{array}{c}5 \% \text { of anticipated } \\
\text { General Fund revenue }\end{array}$ \\
\hline NY & Tax Stabilization Reserve Fund & 1945 & 1946 & Statue & Revenue shortfall & No limit \\
\hline NY & Constitutional Reserve Fund & 1993 & 1994 & General Fund surplus & Appropriation & No limit \\
\hline NM & Tax Stabilization Reserve & 1966 & 1967 & & & \\
\hline
\end{tabular}




\begin{tabular}{|c|c|c|c|c|c|c|}
\hline State & Fund Name & $\begin{array}{c}\text { Year } \\
\text { Adopted }\end{array}$ & $\begin{array}{c}\text { First } \\
\text { Balance }\end{array}$ & Deposit Rule & Withdrawal Rule & Maximum Fund Size \\
\hline NV & Budget Stabilization Designation & 1994 & 1994 & Statutory formula & Revenue shortfall & $\begin{array}{c}8 \% \text { of General Fund } \\
\text { revenue }\end{array}$ \\
\hline $\mathrm{OH}$ & Budget Stabilization Fund & 1981 & 1985 & $\begin{array}{c}5 \% \text { of previous year's } \\
\text { General Fund revenue if } \\
\text { surplus is realized }\end{array}$ & Appropriation & No limit \\
\hline $\mathrm{OK}$ & Constitutional Reserve Fund & 1986 & 1988 & $\begin{array}{c}10 \% \text { of previous year's } \\
\text { General fund revenue if } \\
\text { surplus is realized }\end{array}$ & $\begin{array}{c}\text { Governor request and } 2 / 3 \\
\text { legislative approval or } 3 / 4 \\
\text { legislative approval }\end{array}$ & No limit \\
\hline OR & -- & -- & -- & -- & -- & -- \\
\hline PA & Tax Stabilization Reserve Fund & 1985 & 1986 & $\begin{array}{c}15 \% \text { of General Fund } \\
\text { surplus }\end{array}$ & $2 / 3$ legislative approval & $\begin{array}{c}3 \% \text { of anticipated } \\
\text { General Fund Revenue }\end{array}$ \\
\hline RI & $\begin{array}{c}\text { Budget Reserve and Cash } \\
\text { Stabilization Account }\end{array}$ & 1985 & 1985 & Appropriation & Revenue shortfall & $3 \%$ of resources \\
\hline $\mathrm{SC}$ & General Reserve Fund & 1978 & 1978 & $\begin{array}{c}\text { Statute requiring } 3 \% \text { of } \\
\text { previous year's General } \\
\text { Fund revenue }\end{array}$ & $\begin{array}{l}\text { Revenue shortfall and } \\
\text { zero balance in CRF }\end{array}$ & No limit \\
\hline $\mathrm{SC}$ & Capital Reserve Fund & 1986 & 1986 & $\begin{array}{c}\text { Statute requiring } 2 \% \text { of } \\
\text { previous year's General } \\
\text { Fund revenue }\end{array}$ & Revenue shortfall & No limit \\
\hline SD & Budget Reserve Fund & 1991 & 1992 & General Fund surplus & Revenue shortfall & $\begin{array}{c}5 \% \text { of General Fund } \\
\text { appropriations }\end{array}$ \\
\hline $\mathrm{TN}$ & Revenue Fluctuation Reserve & 1972 & 1972 & $\begin{array}{l}10 \% \text { of estimated tax } \\
\text { revenue growth }\end{array}$ & Revenue shortfalls & $\begin{array}{c}5 \% \text { of estimated tax } \\
\text { revenue }\end{array}$ \\
\hline $\mathrm{TX}$ & Economic Stabilization Fund & 1987 & 1990 & $\begin{array}{l}1 / 2 \text { of General Fund } \\
\text { surplus plus oil \& gas } \\
\text { royalties }\end{array}$ & $\begin{array}{l}\text { Revenue shortfall or } \\
\text { appropriation }\end{array}$ & $\begin{array}{c}10 \% \text { of General Fund } \\
\text { revenue }\end{array}$ \\
\hline UT & Budget Reserve Account & 1986 & 1987 & $\begin{array}{c}25 \% \text { of General Fund } \\
\text { surplus }\end{array}$ & Revenue shortfall & $\begin{array}{c}8 \% \text { of General Fund } \\
\text { appropriations }\end{array}$ \\
\hline VA & Revenue Stabilization Fund & 1992 & 1995 & Statutory formula & Statutory formula & $\begin{array}{c}10 \% \text { of annual tax } \\
\text { revenues }\end{array}$ \\
\hline VT & Budget Stabilization Trust Fund & 1988 & 1988 & General Fund surplus & Revenue shortfall & $\begin{array}{c}5 \% \text { of prior year's } \\
\text { appropriations }\end{array}$ \\
\hline WA & Emergency Reserve Fund & 1981 & 1989 & $\begin{array}{c}100 \% \text { of General Fund } \\
\text { surplus }\end{array}$ & $2 / 3$ legislative approval & $\begin{array}{c}5 \% \text { of biennial General } \\
\text { Fund revenue }\end{array}$ \\
\hline
\end{tabular}




\begin{tabular}{|c|c|c|c|c|c|c|}
\hline State & Fund Name & $\begin{array}{c}\text { Year } \\
\text { Adopted }\end{array}$ & $\begin{array}{c}\text { First } \\
\text { Balance }\end{array}$ & Deposit Rule & Withdrawal Rule & Maximum Fund Size \\
\hline WI & Required Reserve & 1981 & 1981 & $\begin{array}{c}1 \% \text { of General Fund } \\
\text { revenue }\end{array}$ & Revenue shortfall & No limit \\
\hline WI & Budget Stabilization Fund & 1985 & 1985 & Appropriation & Appropriation & No limit \\
\hline WV & Revenue Shortfall Reserve Fund & 1994 & 1995 & General Fund surplus & Revenue shortfall & $\begin{array}{c}5 \% \text { of General Fund } \\
\text { appropriations }\end{array}$ \\
\hline WY & Budget Reserve Account & 1982 & 1983 & Appropriation & Appropriation & $\begin{array}{c}5 \% \text { of estimated General } \\
\text { Fund revenue }\end{array}$ \\
\hline
\end{tabular}

Notes: ${ }^{*}$ Mineral income includes royalties, rent, income tax, production tax, and property tax revenue obtained from minerals. Source: Phone survey of states. 
to determine deposits and withdrawals. These states include Arizona, Indiana, Michigan, and Virginia. In general, the statues governing such funds stipulate that deposits and withdrawals can only be made when the growth in real personal income (or some similar economic indicator) exceeds or falls below some established level. Sobel and Holcombe (1996a) find that states which are required to save in their stabilization funds experienced significantly less fiscal stress during the 1990-1991 recession, and Knight and Levinson (1999a) find that over the period from 1984 to 1997 states with deposit and withdrawal formulas saved significantly more than states whose funds were not subject to such requirements.

In contrast to 'stringent funds,' a majority of states have structured stabilization funds so that deposits and withdraws occur at the discretion of the state's decisionmakers, and thus would fall into a classification of 'weak funds.' Sobel and Holcombe (1996a) find that states that were not required to save in their budget stabilization funds had negligible balances entering the 1990-1991 recession. At least on the surface, a weak stabilization fund would seem to be more substitutable with the state's general fund since legislators can more easily allocate the funds for any purpose. However, if legislators of a given state are committed to saving and thus do not access their stabilization funds unless they are truly needed, states adopting 'weak funds' may benefit. From the standpoint of existing research it does seem as though states will be better off (enhancing their fiscal position) with the adoption of 'stringent funds' as opposed to 'weak funds.'

Despite the evidence suggesting that stringent funds enhance a state's fiscal position, visual inspection of aggregate per capita total balances and aggregate per capita 
stabilization balances, which is shown in Figure 5.1, does not reveal much of a noticeable relationship. $^{42}$

\section{Figure 5.1 - Average Per Capita Budget Stabilization Fund Balances and Average Per CapitaTotal Balances 1975-1996 (in 1992 dollars)}

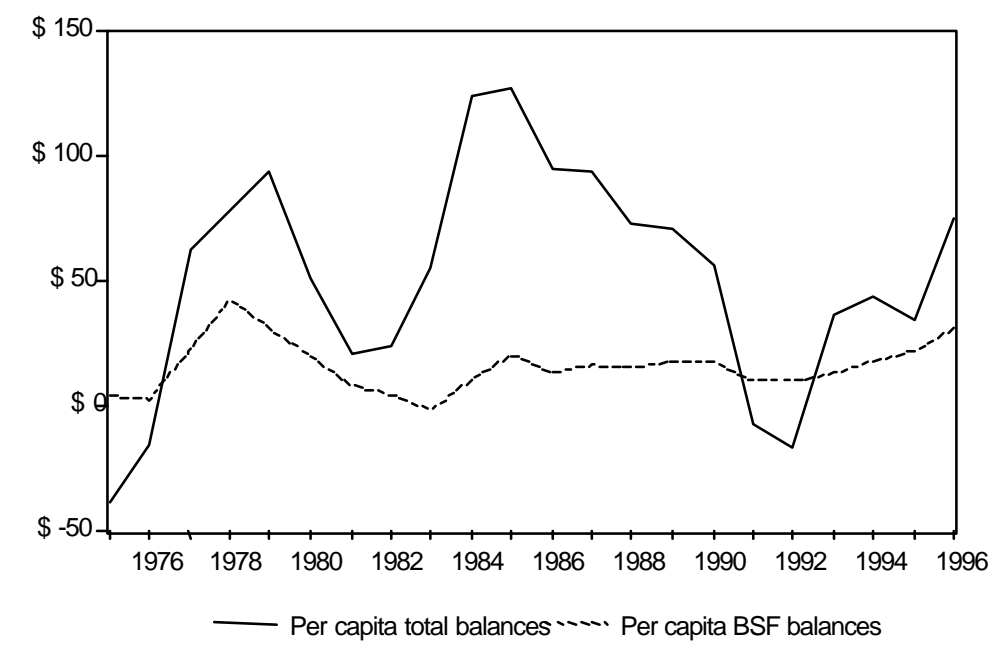

Notes: Only includes states with stabilization funds.

Aside from the apparent simultaneous increase in average per capita total balances and average per capita BSF balances that occurred in the late 1970s, average per capita BSF balances have remained fairly stable while average per capita total balances show considerable volatility. Thus, the raw data seem to suggest that average per capita total

\footnotetext{
${ }^{42}$ Figure 1 includes only states which utilize budget stabilization funds. Thus, AL, AR, HI, IL, MT, and OR are excluded. According to the National Conference of State Legislatures (NCSL) and National Association of State Budget Offices (NASBO), Alabama has a budget stabilization fund. Discussions with Carolyn Middleton of Alabama's Executive Budget Office revealed that Alabama's budget is separated between education and the general fund and are voted on by the Legislature separately. In addition, the stabilization fund utilized by AL can only be used for deficits in education expenditures, and thus is not a general fund account stabilization fund.
} 
balances are not very responsive to changes in average per capita BSF balances. This of course does not imply that the level of average per capita total balances is not higher since the introduction of stabilization funds, only that changes in average per capita total balances do not closely mirror changes in average per capita BSF balances.

One feature that the raw data reveals is that states have accessed their stabilization funds quite frequently over the period from 1975 to 1996. As Table 5.2 illustrates, during this period the percentage of states with stabilization funds that have either deposited or

Table 5.2 - Budget Stabilization Fund Usage 1975-1996

\begin{tabular}{c|c|c|c|c}
\hline \hline Year & $\begin{array}{c}\text { Number of states } \\
\text { depositing }\end{array}$ & $\begin{array}{c}\text { Percentage of } \\
\text { states with funds } \\
\text { depositing }\end{array}$ & $\begin{array}{c}\text { Number of states } \\
\text { withdrawing }\end{array}$ & $\begin{array}{c}\text { Percentage of } \\
\text { states with funds } \\
\text { withdrawing }\end{array}$ \\
\hline \hline & & & & \\
1975 & 2 & 50 & 2 & 50 \\
1976 & 1 & 17 & 4 & 67 \\
1977 & 3 & 38 & 3 & 38 \\
1978 & 5 & 56 & 3 & 33 \\
1979 & 6 & 60 & 3 & 30 \\
1980 & 2 & 20 & 7 & 70 \\
1981 & 5 & 36 & 5 & 36 \\
1982 & 4 & 24 & 6 & 35 \\
1983 & 7 & 35 & 4 & 30 \\
1984 & 14 & 64 & 6 & 18 \\
1985 & 16 & 64 & 10 & 24 \\
1986 & 11 & 37 & 3 & 93 \\
1987 & 23 & 70 & 11 & 32 \\
1988 & 17 & 50 & 9 & 26 \\
1989 & 21 & 62 & 17 & 46 \\
1990 & 13 & 35 & 22 & 56 \\
1991 & 9 & 23 & 14 & 34 \\
1992 & 18 & 44 & 10 & 24 \\
1993 & 24 & 59 & 10 & 23 \\
1994 & 28 & 65 & 15 & 35 \\
1995 & 25 & 58 & 8 & 19 \\
1996 & 33 & 77 & & \\
\hline \hline
\end{tabular}

For states with multiple funds, it is considered a deposit if the sum of all fund balances in year $t$ exceed the sum of all fund balances in year $\mathrm{t}-1$. Withdrawals are determined analogously. 
withdrawn funds in a given year has averaged more than 80 percent. The most active year during this period (excluding 1975 when only 4 states had stabilization funds) was 1995 when 93 percent of states utilizing stabilization funds either deposited or withdrew funds. Even though 1995 was a period of aggregate economic expansion, 35 percent of states with stabilization funds withdrew funds. In fact, during the recent expansion (1992-1996) an average of 27 percent of states utilizing stabilization funds withdrew funds in any given year. While this may seem high, a majority of states withdraw funds only in the event of a revenue shortfall. This means most states may withdraw funds at any time when actual revenues are less than forecasted revenues. Thus withdraws during expansions can occur even for the most fiscally disciplined state.

The next section of the chapter outlines the empirical methodology used to examine how states' behavior has changed since enacting BSFs.

\subsection{Estimating the Change between States' Pre-Budget Stabilization Fund and Budget Stabilization Fund Savings Behavior}

\subsubsection{Specifying the transfer function model}

In the empirical models, a transfer function is estimated for each state on its real contribution to savings in a given year (or rate of savings) and then separately on its total quantity of real funds available in any given year (or total balances). A state's rate of saving $\left(R S_{t}\right)$ is defined as the real change in the fiscal year-end balance of the state's general fund from the previous year plus the real change in the state's BSF balance,

divided by the state's revenue. This provides a measure of the state's contributions to total 
balances in any given year as a percentage of revenue collected. ${ }^{43} \mathrm{~A}$ state's total balances $\left(T B_{t}\right)$ is the state's fiscal year-end general fund surplus plus the balance in the state's BSF. As Gold (1995) claims, the total balances available to a state at any given time is perhaps the best indicator of a state's fiscal health. If states have only retained existing funds longer and not actually contributed more to savings during their BSF usage, then one would expect to find a statistical difference in the state's total balances, but not in rate of savings, between its pre-BSF and BSF years. If on the other hand, states have increased their annual contributions to total balances during their BSF years then one would expect to find statistical differences in the state's rate of saving and total balances.

To examine how a state's savings behavior with a budget stabilization fund compares to their savings behavior without a budget stabilization fund, a transfer function is applied to an autoregressive moving average (ARMA) model for each state's rate of saving and total balances. ${ }^{44} \mathrm{~A}$ transfer function is a series of binary variables, or interventions, which are used to determine the impact that some known event has had on a particular time-series of interest. In its simplest form, a transfer function is simply the coefficient of the intervention variable (or binary variable) which is applied to a given time-series (such as an ARMA) model. If an event occurred at time $t$ which was assumed to have a permanent effect on a particular time-series, the transfer function is the coefficient of this intervention variable (which equals zero prior to the event occurring

\footnotetext{
${ }^{43}$ All figures were deflated using the CPI (1992=100).

${ }^{44}$ See Enders (1995), Mills (1990), and McCleary and Hay (1980) for a discussion of intervention analysis and transfer functions.
} 
and one in every subsequent period) and is interpreted as the change in the level of the time-series due to the intervention. ${ }^{45}$

While obtaining estimates of the total behavioral change states have experienced is of primary interest, separate transfer functions are specified for both adopting, and depositing in, a BSF because many states adopted BSFs several years prior to depositing funds. For instance, Ohio formally adopted a BSF in 1981 but did not have a positive balance until 1985. If such a state changes its savings behavior after adopting a BSF, such as retaining higher balances in the general fund with the intention of later transferring those funds to the BSF, then ignoring the potential impact of adopting a BSF may bias downward the estimated total change experienced by states.

The general form of each transfer function used is $v(L)=\frac{\omega_{0}}{1-\delta_{1} \cdot L} I_{t}$, where $I_{t}$ is the intervention variable which specifies the year of the intervention event, $\omega_{0}$ is the initial impact, or short-run effect, of the intervention, $\delta_{1}$ is the "decay rate" of the initial impact, and $L$ is the standard lag operator. The functional form of the model estimated for each state's rate of saving and total balances may be expressed as:

$$
y=\alpha_{0}+\sum_{i=1}^{p} \alpha_{i} y_{t-i}+\sum_{i=0}^{q} \beta_{i} \varepsilon_{t-i}+\frac{\omega_{A}}{1-\delta_{A} \cdot L} A_{t}+\frac{\omega_{D}}{1-\delta_{D} \cdot L} D_{t}
$$

where $y$ is either the state's rate of saving or the state's total balances, $\alpha_{i}$ and $\beta_{i}$ are the coefficients of the $p$ autoregressive terms and $q$ moving average terms respectively, $A_{t}$ is

\footnotetext{
45 Transfer function models are similar to a standard test between two means, but because many time-series processes are serially correlated such a test is likely to yield questionable results. A properly specified transfer function model will account for the possibility of serial correlation by ensuring the residuals in the model approximate white noise.
} 
the intervention term for a state's adoption of a BSF, and $D_{t}$ is the intervention term for a state's first deposit into the BSF. ${ }^{46}$ While the estimated mean of a 'standard' ARMA model is $\frac{\alpha_{0}}{1-\sum_{i=1}^{p} \alpha_{i}}$ with $\sum_{i=1}^{p} \alpha_{i}<1$ to ensure stationarity, the estimated mean of the series with the interventions specified above is $\frac{\alpha_{0}}{1-\sum_{i=1}^{p} \alpha_{i}}+\frac{\omega_{A}}{1-\delta_{A}}+\frac{\omega_{D}}{1-\delta_{D}}$ with $\sum_{i=1}^{p} \alpha_{i}<1$, $\left|\delta_{A}\right|<1$, and $\left|\delta_{D}\right|<1$ to ensure stationarity. Thus the intervention terms provide one manner in which to estimate how a state's behavior has changed as a result of adopting, and depositing in, a BSF. ${ }^{47}$

Prior to estimating the intervention models, a stationary ARMA model for each state's rate of saving and total balances was specified. ${ }^{48}$ The ordered criteria used to select the AR and MA lags were: (1) insignificance of the Ljung-Box $Q$-Statistic (1979) for

\footnotetext{
${ }^{46}$ Since 14 of the 44 states with BSFs had positive balances in the year in which the fund was adopted (see Table 5.1), only one transfer function is modeled for these states because it is not possible to isolate both the impact of adopting and depositing.

${ }^{47}$ While the empirical models include separate interventions for adopting and depositing in BSFs, including only one intervention term for the year of BSF adoption would also allow one to estimate the total behavioral change between pre-BSF and BSF savings behavior, albeit without specific effects for adopting and depositing.

48 Augmented Dickey-Fuller (1979) tests were performed on each state's rate of saving and total balances for the period from 1946 to one year prior to the first intervention, which for most states was one year prior to BSF adoption. The sample periods for New York (1915-1944), Florida (1938-1958), New Mexico (1938-1965), and Alaska (19601985) differed since NY, FL, and NM adopted BSFs much earlier than other states, and AK did not receive statehood until 1959. The stationarity tests are reported in Tables $\mathrm{C} 1$ and C2 located in Appendix C.
} 
residual serial correlation; (2) Box-Jenkins (1976) notion of parsimony for the significance of AR and MA terms; and (3) lowest Bayesian Information Criterion (BIC).

The stationarity of each series has implications for the structure of the intervention term. If a given state's rate of savings is stationary, then specifying the intervention terms to equal zero in all years prior to the occurrence of the respective intervention, and unity in other all years, implies that the intervention is assumed to exhibit a permanent effect. To model the same impact on a nonstationary series, or series which has been first differenced, the intervention term must also be first differenced. In this case the intervention variable takes on the value of unity in the year of the intervention and equals zero in all other years. This formulation is equivalent to modeling a permanent impact when the series is stationary. Thus for all states whose rate of saving and total balances are stationary or trend stationary, the intervention variables equal zero prior to either adopting, or depositing in, a BSF and equal unity in every subsequent year. For the states whose series must be first differenced to ensure stationarity, the intervention variables equal unity only in the year in which the state either adopted, or deposited in, a BSF and equal zero in all other years. Specifying the intervention variables differently according to the stationarity of each series ensures that the interpretation of the transfer function holds across all states regardless of the stationarity of the series.

Statistical differences exist in the savings behavior of states between a state's preBSF years and BSF years if the estimated mean of the state's rate of saving or estimated mean of its total balances is different between the two periods. If states have been contributing more to savings as a result of utilizing budget stabilization funds, then one 
would expect to find a positive and significant change in the state's rate of saving between its pre-BSF and BSF years. If on the other hand, states are not contributing more to savings but are retaining the funds they do save longer, then one would expect to find a positive and significant change in the state's total balances but an insignificant change in the state's rate of saving.

\subsubsection{Results of Intervention Estimates}

The estimates of the change in each state's average rate of saving and average total balances between each state's pre-BSF and BSF savings behavior are reported in Tables 5.3 and 5.4 and provide some interesting findings. ${ }^{49}$

Beginning with individual states' savings rates $\left(R S_{t}\right)$ which are located in Table 5.3, the estimated change in states' behavior resulting from adoption, depositing, and the total estimated change are reported in separate columns. As the results indicate, while most states' average rate of saving is higher during the BSF period, nearly all states did not experience statistically significant gains. In fact, the estimates reveal that only Kentucky contributed significantly more to savings in a given fiscal year when budget

\footnotetext{
49 The maximum likelihood estimates of each state's initial impact and "rate of decay" are in Tables D1 and D2 located in Appendix D. Since the intervention models 'fit the data,' each state's intervention model was estimated with both short-run transfer functions $\left(\omega_{A}\right.$ and $\left.\omega_{D}\right)$ and short and long-run transfer functions. The model with the lowest Bayesian Information Criterion (BIC) was then selected contingent on the insignificance of the Ljung-Box $Q$-Statistic. Thus states whose behavior was better modeled with only an initial impact term have no decay terms reported.
} 
Table 5.3 - Estimated Change in States' Savings Rates

Dependent variable: $R S_{t}=($ Current Savings/Revenue $) * 100$

\begin{tabular}{|c|c|c|c|c|c|c|c|}
\hline State & $\begin{array}{l}\text { Adoption } \\
\text { Impact }\end{array}$ & $\begin{array}{c}\text { First } \\
\text { Deposit } \\
\text { Impact } \\
\end{array}$ & $\begin{array}{c}\text { Total } \\
\text { Estimated } \\
\text { Change } \\
\end{array}$ & State & $\begin{array}{c}\text { Adoption } \\
\text { Impact }\end{array}$ & $\begin{array}{l}\text { First Deposit } \\
\text { Impact }\end{array}$ & $\begin{array}{c}\text { Total } \\
\text { Estimated } \\
\text { Change } \\
\end{array}$ \\
\hline AK & $\begin{array}{c}4.617 \\
(19.145)\end{array}$ & $\begin{array}{c}3.493 \\
(24.379)\end{array}$ & $\begin{array}{c}8.110 \\
(17.463)\end{array}$ & ND & $\begin{array}{c}-0.392 \\
(3.603)\end{array}$ & $\begin{array}{c}2.428 \\
(4.827)\end{array}$ & $\begin{array}{c}2.036 \\
(2.019)\end{array}$ \\
\hline $\mathrm{AZ}$ & $\begin{array}{c}1.200 \\
(2.746)\end{array}$ & $\begin{array}{l}-0.375 \\
(4.016)\end{array}$ & $\begin{array}{c}0.825 \\
(3.137)\end{array}$ & $\mathrm{NE}$ & $\begin{array}{l}-3.186 \\
(2.936)\end{array}$ & $\begin{array}{l}3.380^{* * *} \\
(0.403)^{\dagger}\end{array}$ & $\begin{array}{c}0.195 \\
(5.755)^{\dagger}\end{array}$ \\
\hline $\mathrm{CA}$ & $\begin{array}{c}2.423 \\
(6.666)\end{array}$ & $\begin{array}{l}-1.951 \\
(6.719)\end{array}$ & $\begin{array}{c}0.472 \\
(1.891)\end{array}$ & $\mathrm{NH}$ & -- & $\begin{array}{l}-0.607 \\
(2.230)\end{array}$ & $\begin{array}{l}-0.607 \\
(2.230)\end{array}$ \\
\hline $\mathrm{CO}$ & $\begin{array}{l}-5.546 \\
(4.010)\end{array}$ & $\begin{array}{c}6.706 \\
(4.122)\end{array}$ & $\begin{array}{c}1.160 \\
(0.928)\end{array}$ & $\mathrm{NJ}$ & $\begin{array}{l}-1.193 \\
(5.336)\end{array}$ & $\begin{array}{c}2.280 \\
(6.999)\end{array}$ & $\begin{array}{c}1.087 \\
(4.606)\end{array}$ \\
\hline CT & $\begin{array}{c}1.648 \\
(6.211)\end{array}$ & $\begin{array}{l}-0.456 \\
(6.781)\end{array}$ & $\begin{array}{c}1.192 \\
(4.425)\end{array}$ & NM & $\begin{array}{l}-2.863 \\
(5.529)\end{array}$ & $\begin{array}{c}2.648 \\
(5.515)\end{array}$ & $\begin{array}{l}-0.215 \\
(0.829)\end{array}$ \\
\hline $\mathrm{DE}$ & -- & $\begin{array}{c}3.617 \\
(3.552)\end{array}$ & $\begin{array}{c}3.617 \\
(3.552)\end{array}$ & NY & $\begin{array}{l}-1.324 \\
(1.459)\end{array}$ & $\begin{array}{c}1.127 \\
(2.318)\end{array}$ & $\begin{array}{l}-0.197 \\
(2.269)\end{array}$ \\
\hline FL & $\begin{array}{c}2.904 \\
(2.458)\end{array}$ & $\begin{array}{l}-2.007 \\
(2.325)\end{array}$ & $\begin{array}{c}0.897 \\
(1.480)\end{array}$ & $\mathrm{NV}$ & -- & $\begin{array}{c}2.738 \\
(3.032)\end{array}$ & $\begin{array}{c}2.738 \\
(3.032)\end{array}$ \\
\hline GA & -- & $\begin{array}{c}0.270 \\
(1.485)\end{array}$ & $\begin{array}{c}0.270 \\
(1.485)\end{array}$ & $\mathrm{OH}$ & $\begin{array}{c}2.361 \\
(2.821)\end{array}$ & $\begin{array}{l}-1.521 \\
(3.086)\end{array}$ & $\begin{array}{c}0.840 \\
(1.787)\end{array}$ \\
\hline IA & $\begin{array}{c}0.635 \\
(2.076)\end{array}$ & $\begin{array}{c}1.139 \\
(3.265)\end{array}$ & $\begin{array}{c}1.774 \\
(2.659)\end{array}$ & OK & $\begin{array}{l}-1.549^{* *} \\
(0.692)^{\dagger}\end{array}$ & $\begin{array}{c}1.317 \\
(1.959)\end{array}$ & $\begin{array}{c}-0.233 \\
(2.645)^{\dagger}\end{array}$ \\
\hline ID & -- & $\begin{array}{c}1.184 \\
(0.929)\end{array}$ & $\begin{array}{c}1.184 \\
(0.929)\end{array}$ & PA & $\begin{array}{l}-0.433 \\
(7.592)\end{array}$ & $\begin{array}{l}-0.257 \\
(7.856)\end{array}$ & $\begin{array}{l}-0.690 \\
(2.591)\end{array}$ \\
\hline IN & $\begin{array}{c}3.756 \\
(4.084)\end{array}$ & $\begin{array}{c}-3.366 \\
(206.685)^{\dagger}\end{array}$ & $\begin{array}{c}0.389 \\
(206.127)^{\dagger}\end{array}$ & RI & -- & $\begin{array}{c}0.132 \\
(2.897)\end{array}$ & $\begin{array}{c}0.132 \\
(2.897)\end{array}$ \\
\hline $\mathrm{KS}$ & -- & $\begin{array}{c}1.426 \\
(3.404)\end{array}$ & $\begin{array}{c}1.426 \\
(3.404)\end{array}$ & $\mathrm{SC}$ & -- & $\begin{array}{c}0.317 \\
(1.809)\end{array}$ & $\begin{array}{c}0.317 \\
(1.809)\end{array}$ \\
\hline KY & -- & $\begin{array}{l}1.460^{*} \\
(0.801)\end{array}$ & $\begin{array}{l}1.460^{*} \\
(0.801)\end{array}$ & SD & $\begin{array}{c}5.980 \\
(7.892)\end{array}$ & $\begin{array}{l}-5.892 \\
(9.467)\end{array}$ & $\begin{array}{c}0.088 \\
(2.285)\end{array}$ \\
\hline LA & $\begin{array}{l}-1.583 \\
(1.682)\end{array}$ & -- & $\begin{array}{l}-1.583 \\
(1.682)\end{array}$ & $\mathrm{TN}$ & -- & $\begin{array}{c}0.050 \\
(0.981)\end{array}$ & $\begin{array}{c}0.050 \\
(0.981)\end{array}$ \\
\hline MA & $\begin{array}{c}1.232 \\
(6.551)\end{array}$ & $\begin{array}{c}-1.482 \\
(106.876)^{\dagger}\end{array}$ & $\begin{array}{c}-0.251 \\
(106.256)^{\dagger}\end{array}$ & $\mathrm{TX}$ & $\begin{array}{c}0.293 \\
(2.482)\end{array}$ & $\begin{array}{l}-0.910 \\
(2.863)\end{array}$ & $\begin{array}{l}-0.617 \\
(1.696)\end{array}$ \\
\hline MD & $\begin{array}{l}-1.379 \\
(5.564)\end{array}$ & $\begin{array}{c}1.645 \\
(5.764)\end{array}$ & $\begin{array}{c}0.266 \\
(1.942)\end{array}$ & UT & $\begin{array}{l}-4.482 \\
(5.239)\end{array}$ & $\begin{array}{c}5.503 \\
(5.438)\end{array}$ & $\begin{array}{c}1.021 \\
(1.429)\end{array}$ \\
\hline ME & -- & $\begin{array}{l}-0.063 \\
(1.004)\end{array}$ & $\begin{array}{l}-0.063 \\
(1.004)\end{array}$ & VA & $\begin{array}{c}1.917 \\
(2.323)\end{array}$ & $\begin{array}{l}-2.509 \\
(4.533)\end{array}$ & $\begin{array}{l}-0.592 \\
(3.341)\end{array}$ \\
\hline MI & $\begin{array}{c}5.989 \\
(5.060)\end{array}$ & $\begin{array}{l}-5.089^{* * *} \\
(1.838)^{\dagger}\end{array}$ & $\begin{array}{c}0.899 \\
(7.630)^{\dagger}\end{array}$ & VT & -- & $\begin{array}{l}-0.399 \\
(2.296)\end{array}$ & $\begin{array}{l}-0.399 \\
(2.296)\end{array}$ \\
\hline $\mathrm{MN}$ & $\begin{array}{c}0.307 \\
(4.740)\end{array}$ & $\begin{array}{c}0.063 \\
(5.047)\end{array}$ & $\begin{array}{c}0.370 \\
(2.558)\end{array}$ & WA & $\begin{array}{c}0.476 \\
(1.839)\end{array}$ & $\begin{array}{l}-0.848 \\
(2.429)\end{array}$ & $\begin{array}{l}-0.372 \\
(1.841)\end{array}$ \\
\hline MO & -- & $\begin{array}{c}1.861 \\
(2.422)\end{array}$ & $\begin{array}{c}1.861 \\
(2.422)\end{array}$ & WI & -- & $\begin{array}{c}0.734 \\
(0.892)\end{array}$ & $\begin{array}{c}0.734 \\
(0.892)\end{array}$ \\
\hline MS & $\begin{array}{c}2.731 \\
(5.656)\end{array}$ & $\begin{array}{l}-1.851 \\
(5.774)\end{array}$ & $\begin{array}{c}0.880 \\
(1.754)\end{array}$ & WV & $\begin{array}{l}-1.420 \\
(8.207)\end{array}$ & $\begin{array}{c}3.008 \\
(10.496)\end{array}$ & $\begin{array}{c}1.588 \\
(5.134)\end{array}$ \\
\hline $\mathrm{NC}$ & -- & $\begin{array}{c}0.838 \\
(3.278) \\
\end{array}$ & $\begin{array}{c}0.838 \\
(3.278) \\
\end{array}$ & WY & $\begin{array}{c}15.247^{* *} \\
(6.416)\end{array}$ & $\begin{array}{c}-16.860^{* * * *} \\
(6.555)\end{array}$ & $\begin{array}{l}-1.163 \\
(1.661) \\
\end{array}$ \\
\hline
\end{tabular}

Notes: Standard errors in parentheses. Coefficient estimates, including initial impact and decay terms for all models, are reported in Appendix B.

† indicates bootstrapped standard errors obtained from 10,000 Monte Carlo simulations. 
Table 5.4 - Estimated Change in States' Total Balances

Dependent variable: $T B_{t}=$ Total Balances

\begin{tabular}{|c|c|c|c|c|c|c|c|}
\hline State & $\begin{array}{c}\text { Adoption } \\
\text { Impact }\end{array}$ & $\begin{array}{c}\text { First } \\
\text { Deposit } \\
\text { Impact } \\
\end{array}$ & $\begin{array}{c}\text { Total } \\
\text { Estimated } \\
\text { Change } \\
\end{array}$ & State & $\begin{array}{c}\text { Adoption } \\
\text { Impact }\end{array}$ & $\begin{array}{l}\text { First Deposit } \\
\text { Impact }\end{array}$ & $\begin{array}{c}\text { Total } \\
\text { Estimated } \\
\text { Change } \\
\end{array}$ \\
\hline AK & $\begin{array}{c}888.234 \\
(1243.204)\end{array}$ & $\begin{array}{c}624.050 \\
(1042.449)\end{array}$ & $\begin{array}{c}1512.285 \\
(1783.087)\end{array}$ & ND & $\begin{array}{l}-56.360 \\
(54.266)\end{array}$ & $\begin{array}{c}130.889^{* *} \\
(57.847)\end{array}$ & $\begin{array}{c}74.529 \\
(47.592)\end{array}$ \\
\hline $\mathrm{AZ}$ & $\begin{array}{l}-227.202 \\
(227.641)\end{array}$ & $\begin{array}{c}184.053 \\
(264.137)\end{array}$ & $\begin{array}{c}-43.154 \\
(321.948)\end{array}$ & $\mathrm{NE}$ & $\begin{array}{l}-11.280 \\
(38.670)\end{array}$ & $\begin{array}{l}82.315^{\text {*** }} \\
(30.514)^{\dagger}\end{array}$ & $\begin{array}{l}71.021^{* * *} \\
(42.956)^{\dagger}\end{array}$ \\
\hline $\mathrm{CA}$ & $\begin{array}{l}-1984.857 \\
(1880.915)\end{array}$ & $\begin{array}{l}3145.902^{*} \\
(1852.051)\end{array}$ & $\begin{array}{c}1164.045 \\
(1482.672)\end{array}$ & $\mathrm{NH}$ & -- & $\begin{array}{c}-23.016 \\
(14.224)\end{array}$ & $\begin{array}{l}-23.016 \\
(14.224)\end{array}$ \\
\hline $\mathrm{CO}$ & $\begin{array}{l}-366.796^{*} \\
(208.919)\end{array}$ & $\begin{array}{l}462.273^{* *} \\
(602.930)\end{array}$ & $\begin{array}{c}94.476 \\
(100.667)\end{array}$ & $\mathrm{NJ}$ & $\begin{array}{l}-474.975 \\
(592.354)\end{array}$ & $\begin{array}{c}917.970 \\
(564.923)\end{array}$ & $\begin{array}{c}442.994 \\
(846.051)\end{array}$ \\
\hline $\mathrm{CT}$ & $\begin{array}{c}434.507 \\
(263.096)\end{array}$ & $\begin{array}{c}210.068 \\
(279.419)\end{array}$ & $\begin{array}{l}644.575^{* * *} \\
(220.460)\end{array}$ & NM & $\begin{array}{c}38.627 \\
(126.167)\end{array}$ & $\begin{array}{c}47.041 \\
(126.517)\end{array}$ & $\begin{array}{c}85.668 \\
(252.860)\end{array}$ \\
\hline $\mathrm{DE}$ & -- & $\begin{array}{l}409.396^{* *} \\
(146.644)^{\dagger}\end{array}$ & $\begin{array}{l}409.396^{* *} \\
(146.644)^{\dagger}\end{array}$ & NY & $\begin{array}{l}451.708 \\
(378.32)\end{array}$ & $\begin{array}{c}-115.870 \\
(99.684)\end{array}$ & $\begin{array}{c}335.837 \\
(325.407)\end{array}$ \\
\hline FL & $\begin{array}{c}167.591 \\
(248.862)\end{array}$ & $\begin{array}{l}-120.251 \\
(237.491)\end{array}$ & $\begin{array}{c}47.340 \\
(166.837)\end{array}$ & NV & -- & $\begin{array}{c}139.693^{* * * *} \\
(49.614)\end{array}$ & $\begin{array}{c}139.693^{* * *} \\
(49.614)\end{array}$ \\
\hline GA & -- & $\begin{array}{c}318.096 \\
(242.978)\end{array}$ & $\begin{array}{c}318.096 \\
(242.978)\end{array}$ & $\mathrm{OH}$ & $\begin{array}{c}58.976 \\
(441.516)\end{array}$ & $\begin{array}{l}828.421^{*} \\
(441.695)\end{array}$ & $\begin{array}{c}887.398 \\
(630.738)\end{array}$ \\
\hline IA & $\begin{array}{c}-14.036 \\
(95.983)\end{array}$ & $\begin{array}{c}155.091 \\
(120.769)\end{array}$ & $\begin{array}{c}141.054 \\
(116.660)\end{array}$ & OK & $\begin{array}{l}-371.653^{* *} \\
(143.447)\end{array}$ & $\begin{array}{l}334.719^{* *} \\
(140.898)\end{array}$ & $\begin{array}{c}-26.934 \\
(280.080)\end{array}$ \\
\hline ID & -- & $\begin{array}{c}4442.304 \\
(215519.47)^{\dagger}\end{array}$ & $\begin{array}{c}4442.304 \\
(215519.47)^{\dagger}\end{array}$ & PA & $\begin{array}{c}335.983 \\
(728.789)\end{array}$ & $\begin{array}{c}194.723 \\
(732.948)\end{array}$ & $\begin{array}{c}530.707 \\
(688.983)\end{array}$ \\
\hline IN & $\begin{array}{c}175.736 \\
(209.685)\end{array}$ & $\begin{array}{l}448.963^{*} \\
(224.500)\end{array}$ & $\begin{array}{c}624.699^{* * *} \\
(127.719)\end{array}$ & RI & -- & $\begin{array}{c}32.140 \\
(119.174)\end{array}$ & $\begin{array}{c}32.140 \\
(119.174)\end{array}$ \\
\hline $\mathrm{KS}$ & & $\begin{array}{c}189.231 \\
(137.450)\end{array}$ & $\begin{array}{c}189.231 \\
(137.450)\end{array}$ & $\mathrm{SC}$ & -- & $\begin{array}{c}127.193 \\
(110.382)\end{array}$ & $\begin{array}{c}127.193 \\
(110.382)\end{array}$ \\
\hline KY & 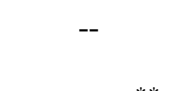 & $\begin{array}{l}305.713^{* *} \\
(152.186)\end{array}$ & $\begin{array}{l}305.713^{\text {** }} \\
(152.186)\end{array}$ & SD & $\begin{array}{c}63.984 \\
(51.906)\end{array}$ & $\begin{array}{c}-33.800 \\
(56.238)\end{array}$ & $\begin{array}{c}30.184 \\
(24.201)\end{array}$ \\
\hline LA & $\begin{array}{c}-338.496^{* *} \\
(150.682)\end{array}$ & -- & $\begin{array}{c}-338.496^{* *} \\
(150.682)\end{array}$ & $\mathrm{TN}$ & -- & $\begin{array}{l}457.557^{*} \\
(231.164)\end{array}$ & $\begin{array}{l}457.557^{*} \\
(231.164)\end{array}$ \\
\hline MA & $\begin{array}{c}650.925 \\
(421.091)\end{array}$ & $\begin{array}{l}-579.003 \\
(431.452)\end{array}$ & $\begin{array}{c}71.921 \\
(293.873)\end{array}$ & $\mathrm{TX}$ & $\begin{array}{c}-980.146^{* *} \\
(460.253)\end{array}$ & $\begin{array}{c}-4.674 \\
(462.204)\end{array}$ & $\begin{array}{c}-984.820^{* *} \\
(490.299)\end{array}$ \\
\hline MD & $\begin{array}{l}-169.725 \\
(285.885)\end{array}$ & $\begin{array}{c}129.177 \\
(246.883)\end{array}$ & $\begin{array}{c}-40.547 \\
(408.408)\end{array}$ & UT & $\begin{array}{c}-49.739 \\
(71.739)\end{array}$ & $\begin{array}{l}130.794^{*} \\
(74.297)\end{array}$ & $\begin{array}{l}81.054^{* * *} \\
(31.295)\end{array}$ \\
\hline $\mathrm{ME}$ & -- & $\begin{array}{l}111.427^{* * *} \\
(54.871)\end{array}$ & $\begin{array}{l}111.427^{* * *} \\
(54.871)\end{array}$ & VA & $\begin{array}{l}370.334^{* *} \\
(148.609)\end{array}$ & $\begin{array}{c}39.423 \\
(179.954)\end{array}$ & $\begin{array}{l}409.758^{* *} \\
(178.454)\end{array}$ \\
\hline MI & $\begin{array}{l}913.900^{*} \\
(522.515)\end{array}$ & $\begin{array}{c}75.793 \\
(528.807)\end{array}$ & $\begin{array}{l}989.694^{* * * *} \\
(248.048)\end{array}$ & VT & -- & $\begin{array}{c}-106.042 \\
(755.632)^{\dagger}\end{array}$ & $\begin{array}{c}-106.042 \\
(755.632)^{\dagger}\end{array}$ \\
\hline $\mathrm{MN}$ & $\begin{array}{l}262.359^{* *} \\
(101.034)^{\dagger}\end{array}$ & $\begin{array}{l}512.084^{* * *} \\
(140.489)\end{array}$ & $\begin{array}{l}774.429^{* * *} \\
(153.000)^{\dagger}\end{array}$ & WA & $\begin{array}{l}-205.521 \\
(178.647)\end{array}$ & $\begin{array}{c}-54.303 \\
(217.856)\end{array}$ & $\begin{array}{l}-259.825 \\
(184.063)\end{array}$ \\
\hline MO & -- & $\begin{array}{c}1781.798^{* *} \\
(410468.91)^{\dagger}\end{array}$ & $\begin{array}{c}1781.798^{* *} \\
(410468.91)^{\dagger}\end{array}$ & WI & -- & $\begin{array}{l}639.186^{* * *} \\
(125.831)\end{array}$ & $\begin{array}{c}639.186^{* * *} \\
(125.831)\end{array}$ \\
\hline MS & $\begin{array}{c}17.034 \\
(121.255)\end{array}$ & $\begin{array}{l}229.530^{*} \\
(123.803)\end{array}$ & $\begin{array}{c}246.564^{* * *} \\
(37.672)\end{array}$ & WV & $\begin{array}{c}-41.942 \\
(109.578)\end{array}$ & $\begin{array}{c}178.497 \\
(111.277)\end{array}$ & $\begin{array}{c}136.555 \\
(132.687)\end{array}$ \\
\hline $\mathrm{NC}$ & -- & $\begin{array}{c}210.431 \\
(207.094) \\
\end{array}$ & $\begin{array}{c}210.431 \\
(207.094) \\
\end{array}$ & WY & $\begin{array}{c}316.666^{* * *} \\
(71.448)\end{array}$ & $\begin{array}{r}-110.736 \\
(70.280)\end{array}$ & $\begin{array}{c}205.930^{* * *} \\
(94.675)\end{array}$ \\
\hline
\end{tabular}

Notes: Standard errors in parentheses. Coefficient estimates, including initial impact and decay terms for all models, are reported in Appendix B.

† indicates bootstrapped standard errors obtained from 10,000 Monte Carlo simulations. 
stabilization funds were used in conjunction with the general fund than when their contributions were retained only in the general fund. ${ }^{50}$ Kentucky's average rate of saving from 1983 to 1996 , the years in the sample that Kentucky had a BSF, was 1.46 percent higher than its average rate of saving from 1946 to $1982 .{ }^{51}$ On the other hand, the fact that 43 of the 44 states which utilize BSFs did not experience significant gains in their rate of saving provides very strong evidence that states have not contributed more to savings each year as a result of enacting BSFs.

The estimated total balance models have states fairing somewhat better than they did in their savings rates. Of the 44 states with stabilization funds, the total estimated change in the state's average total balances for 16 states is positive and significant between their BSF period and pre-BSF period, including Kentucky. Since the total balance model estimates are not adjusted for population, it is difficult to draw conclusions when comparing states. However, as a percentage of 1996 expenditures, the state experiencing the largest increase in average total balances between its BSF years and preBSF years was Missouri. As a percentage of its 1996 budget, Missouri's average total balances during its BSF years was 16.9 percent higher than its average total balances for its pre-BSF years. Delaware and Wyoming also experienced gains in their total balances

\footnotetext{
${ }^{50}$ For states in which both an initial impact and rate of decay were appropriate (see Table D1 and D2 in Appendix D), significance of the long-run impact and total estimated change was determined by Monte Carlo simulation since the long-run effect is a nonlinear transformation of the impact and rate of decay. The standard errors reported for such estimates are bootstrapped standard errors obtained from the simulations.

${ }^{51}$ Incidentally, the finding that Kentucky experienced a significant increase in its savings rate may simply be due to random noise. In a sample size of 44 states, one could expect on average to randomly find 4 states with significantly higher savings rates at the 10 percent level.
} 
of more than 10 percent of their 1996 budget, and the average increase in states' total balances, for those states whose gain was significant, was nearly 6 percent of the 1996 budget.

Despite the sizable gains in total balances experienced by one-third of states, nearly two-thirds of states (28 out of 44) have experienced no significant change in their savings behavior between their BSF years and pre-BSF years. In addition, since only one of the 16 states which did witness statistically higher total balances after utilizing a budget stabilization fund also experienced a significant increase in their rate of savings, this suggests that nearly 95 percent of states which have benefited from BSFs have done so not by saving more, but by retaining existing balances longer. If states have not saved more each year and have a larger average stock of fungible balances in any given year, then it must be the case that states have been retaining the funds that they do save longer. Thus, while the intervention results indicate that BSFs have been perfectly substitutable with the general fund for most states, the few that have gained have done so by retaining balances longer rather than actually saving more.

From a policy perspective, a state's total balances is arguably more important than the rate of savings since states' abilities to survive revenue shortfalls depends on the total quantity of fungible balances available when the shortfall arises (Gold, 1995). The results of the intervention models reveal that nearly two-thirds of states are no better prepared for mitigating revenue shortfalls as a result of enacting a budget stabilization fund, suggesting that BSFs are not an automatic cure for fiscal woes. The one-third of states which have increased the retention of existing funds since utilizing BSFs, and thus have 
significantly higher total balances, have strengthened their ability to deal with periods of fiscal stress relative to when they maintained balances only in the general fund.

\subsection{The Role of Budget Stabilization Fund Characteristics in Influencing Savings Behavior Changes}

The intervention results reveal that for a majority of states budget stabilization funds have been nothing more than substitutes for the state's general fund, implying that most states could be just as well-off fiscally if funds were retained only in the general fund. An important question is why have some states experienced significantly higher total balances and rates of savings after enacting budget stabilization funds while other states have not. A natural point of departure for such an investigation is to examine the role of fund characteristics, such as deposit and withdrawal rules, since there is wide variation across states (see Table 5.1).

To examine the role of fund characteristics in influencing states' behavioral changes, the estimates of each state's total change in their average rate of saving and average total balances after enacting budget stabilization funds are regressed on a set of indicator variables reflecting fund characteristics (which are assumed to be constant over time) and estimated using Weighted Least Squares. Previous research has indicated that fund characteristics may play an important role in the benefits states receive from BSFs. Sobel and Holcombe (1996a) find that states which require deposits in BSFs experienced significantly fewer expenditure reductions below their long-run trend growth during the 1990-1991 recession, and Knight and Levinson (1999a) find that states with stringent withdrawal requirements and no limits on their BSFs saved more than other states with BSFs. 
As the Weighted Least Squares estimates reveal in Table 5.5, relative to the omitted categories of depositing and withdrawing only upon appropriation and limiting the maximum size of the fund to 5 percent or less, fund characteristics play a very important role in the behavioral changes experienced by states after enacting budget stabilization funds. Considered jointly the set of indicator variables are not jointly significant in explaining the estimated change in states' savings rate behavior, but are significant at the 1 percent level in explaining the estimated change in states' total balances behavior.

As for the specific fund characteristics, states which are required to deposit funds by various methods seem to have faired much better than states which deposit only by legislative appropriation. For instance, states which require savings in their budget stabilization funds by limiting the percentage of forecasted revenue they can allocate, which includes Colorado, Kansas, and Wisconsin, had significantly larger gains in their total balances than did states which deposit funds by appropriation, the omitted category. In fact, these states experienced gains in their total balance in excess in \$233 million relative to states which appropriate funds to their BSFs. ${ }^{52}$ States which deposit funds based off a statutory formula, which includes Arizona, Indiana, Michigan, Nevada, and Virginia, experienced significantly larger gains in their rate of saving than do states which deposit by appropriation. Mandating deposits in accordance with state business cycle activity is correlated with states experiencing a 2.4 percent increase in their rate of

\footnotetext{
52 Recall that the Weighted Least Squares coefficients have been normalized by the standard error of states' estimated total changes. Hence the results do not lend themselves to cross-state comparisons. They do however indicate the normalized magnitude gain of specific fund characteristics relative to the omitted categories.
} 


\section{Table 5.5 - Impact of Budget Stabilization Fund Requirements on Estimated Behavioral Change}

\begin{tabular}{l|c|c|}
\hline \hline Variables & Savings Rate Model & Total Balances Model \\
\hline \hline \multirow{2}{*}{ Constant } & 0.411 & $150.820^{* *}$ \\
& $(0.541)$ & $(56.822)$ \\
Deposit by statutory formula & $2.424^{* * *}$ & 32.037 \\
& $(0.400)$ & $(99.370)$ \\
Required deposit by appropriation & -0.095 & $215.430^{*}$ \\
& $(0.446)$ & $(134.680)$ \\
Deposit by General Fund Surplus & 0.130 & -52.761 \\
& $(0.487)$ & $(62.282)$ \\
Limit on Forecast Expenditures & 0.711 & $233.820^{*}$ \\
& $(0.430)$ & $(129.37)$ \\
Withdrawal by statutory formula & $-2.784^{* * *}$ & $320.950^{*}$ \\
& $(0.956)$ & $(164.550)$ \\
Withdrawal by revenue shortfall & -0.268 & $-102.840^{* *}$ \\
& $(0.264)$ & $(48.524)$ \\
Withdrawal by supermajority & $-0.870^{* *}$ & -11.011 \\
F-Test (Model) & $(0.421)$ & $(192.930)$ \\
$R^{2}$ & 0.170 & 59.672 \\
Fund size greater than 5 percent & $(0.293)$ & $(37.045)$ \\
\hline \hline
\end{tabular}

Notes: Standard errors in parentheses. Significance levels are as follows: ${ }^{* * *}$ denotes significance at the 1 percent level, ${ }^{* *}$ at the 5 percent level, and ${ }^{*}$ at the 10 percent level.

saving relative to states that appropriate deposits. In addition, requiring states' decisionmakers to appropriate funds into the BSF, where the amount to deposit is often determined as a percentage of the previous year's revenue, is associated with states experiencing gains in their total balances in excess of $\$ 215$ million relative to states which are not required to appropriate funds. 
Withdrawal requirements more stringent than legislative approval are also influential. Relative to states which withdraw funds by legislative appropriation, states which withdraw funds based off a statutory formula, which include Arizona, Indiana, Michigan, and Virginia, experienced significant behavioral changes in both their savings rate and total balances behavior. While statutory formulas vary somewhat across states, most are structured to coincide with the state's business cycle. In Arizona for instance, withdraws from the state's BSF can only occur when the real annual growth in Arizona's total personal income (excluding transfer payments) is below 2 percent and below the average real annual growth over the previous 7 years. Such states had a 2.7 percent lower rate of saving after enacting a budget stabilization fund. If a statutory formula for withdraws increases the retention rate of balances, then this point estimate is not surprising. If states' decision-makers are forced to retain funds in a BSF because business cycle conditions do not permit withdraws, then such a state could save less each year and continue to maintain the same total quantity of funds as the state maintained when funds were only held in the general fund. Moreover, the states that withdraw funds only by formula experienced total balance increases of more than $\$ 320$ million relative to states that withdraw by legislative approval, which is the largest magnitude of all the indicator variables in the total balance model. ${ }^{53}$

Finally, limits on fund size prove to be an insignificant determinant of the change experienced by states. Although limits on fund sizes generally hover around the recommended 5 percent level of the budget, many states have very large limits (25

\footnotetext{
${ }^{53}$ Alternative empirical specifications of the total balances model in Table 5.5 were also explored. The results of the alternative specifications are in Table E1 in Appendix E.
} 
percent) and others have no limits (Sobel and Holcombe, 1996a). However, given that very few states have had binding limits during any period of their BSF usage, it is not surprising that states whose funds may be greater than 5 percent of the budget have not experienced significant gains relative to states which limit their funds to be five percent of the budget or less.

Considering the results of both the intervention models and Weighted Least Squares estimates, the empirical results provide very strong evidence that budget stabilization funds have been nothing more than substitutes for states' general fund accounts. The estimates also reveal that the fraction of states which have noticeably different behavior as a result of enacting BSFs have gained from retaining the funds they do save longer rather than actually saving more. In addition, the structure of the state's fund is shown to be an influential factor in determining how a state may benefit from a BSF. States whose funds have deposit requirements, either through mandating appropriations or through limiting the allocation of forecasted revenue, and states which withdraw funds by statutory formula, experienced gains in their total balances in excess of $\$ 530$ million relative to states which deposit and withdraw funds solely at the discretion of the state's legislature. Thus for states to actually benefit from utilizing a budget stabilization fund, the empirical results presented here provide very strong evidence that states must adopt a stabilization fund which is much more stringent than the state's general fund. 


\subsection{Conclusions}

The number of states utilizing budget stabilization funds has increased dramatically in the last two decades, bringing the total number of states utilizing such fiscal measures to 44 . At first glance, stabilization funds seem to be perfectly substitutable with states' general funds, however budget stabilization funds have the potential to enhance states' fiscal positions by increasing the retention rate of existing fund balances and/or increasing the rate at which states save. Previous research has indicated that states' fiscal health is enhanced with the adoption of budget stabilization funds, and that the structure of stabilization funds plays a large role in determining whether or not a state will benefit from utilizing a stabilization fund. The literature has suggested that states whose funds possess no maximum limit, stringent deposit rules, and stringent withdrawal rules seem to fair better than states whose funds do not contain such provisions.

Using unpublished data on each state's budget stabilization balance over its entire existence, I estimate a transfer function model to obtain estimates of the change in each state's average rate of savings and average total balances over the entire history of a state's BSF usage. While one-third of states have experienced a significant increase in their total balances since utilizing BSFs, nearly two-thirds of states (28 out of 44 ) have experienced no significant change in their savings behavior between their BSF years and pre-BSF years. Since nearly all of the states with statistically higher total balances after utilizing a budget stabilization fund did not experience a significant increase in their rate of saving, these states have benefited from BSFs by retaining the funds they do save longer rather than contributing more to savings each year. 
In addition, regressing the estimated change in each state's average rate of saving and average total balances on a set of indicator variables reflecting fund characteristics, I find that the structure of a state's fund is an important determinant of the estimated change experienced by states. The estimates, which are consistent with those of Sobel and Holcombe (1996a) and Knight and Levinson (1999a), reveal that states whose funds have explicit rules requiring funds be deposited, and withdraw funds only by statutory formula, experienced significantly larger changes in their total balances as a result of utilizing budget stabilization funds than did states whose funds only permit deposits and withdraws at the discretion of the legislature and limit the size of their fund to be 5 percent of the budget or less. In fact, states which mandate deposits into their BSF and have a statutory formula restricting withdraws, experienced increases in their total balances in excess of $\$ 530$ million relative to states whose funds are governed solely at the discretion of the state's legislature.

Thus while budget stabilization funds appear to be perfectly substitutable with most states' general funds, this is by no means suggestive that budget stabilization funds are an ineffective means of saving for states. In fact, the empirical results provide very strong evidence that BSFs which are stringent, meaning states' decision-makers are required to deposit funds and are limited to withdrawing funds only in accordance with business cycle activity, greatly increases the likelihood that a state will save more after utilizing a BSF. Thus states seeking to enhance their fiscal positions and expand their ability to mitigate periods of fiscal stress should enact stringent budget stabilization funds rather than enacting a fund which closely resembles the state's general fund. 


\section{Chapter 6}

\section{Conclusion and Prospects for Future Research}

State governments have long been active savers, yet very little research has been conducted to understand the political and economic aspects of state governments' savings behavior. Despite the lack of research, states' use of savings in fiscal policy choices plays a central role in states' abilities to mitigate periods in which expenditure demands exceed states' supply of available balances. States' opportunities for weathering recessions without the need for expenditure reductions, tax increases, or the issuance of new debt is dependent on states' supply of reserve balances. The most dramatic change in states' efforts to retain such reserve balances has been the use of budget stabilization funds, often referred to as rainy day funds, designed to provide states' decision-makers with an additional instrument for saving. While stabilization fund usage by state governments has a long history, it has only been in last twenty years that stabilization funds have become an extremely popular means of saving. This dissertation investigates several aspects of the savings behavior of state governments, including the effectiveness of stabilization funds.

An aspect of state government savings that has not previously been explored is the common pool problem associated with savings in the public sector. Chapter 3 addresses the issue of the common pool problem by investigating how political control influences the current level of states' savings. Unlike private sector individuals, the right to access and spend funds in the public sector is granted to the party or coalition that controls political outcomes. Thus, public sector decision-makers who are currently determining the allocation and composition of spending are not necessarily guaranteed 
the right to continue to make such decisions in the future since their prospect for future decision-making is contingent on remaining in office and retaining political control. As a result of the uncertainty in controlling future political outcomes, political manipulation of a state's current savings by legislators for self-gain may occur if the decision-makers presently controlling political outcomes expect to lose their ability to control political outcomes (and thus the allocation of funds) in the future. Chapter 3 develops a theoretical model which shows that a representative legislator will choose to increase the current level of spending and decrease the current level of saving when his prospects for controlling future political outcomes diminish. An empirical model is also estimated to test the theoretical model. The empirical results provide strong evidence in support of the notion that states' legislators opt to increase current spending and reduce current saving when a change in the future controlling party of states' lower houses is expected. The empirical results imply that state governments' savings may be systematically adversely affected by anticipated political changes. Hence, states that are more politically unstable than other states should be ill-prepared to deal with recessions relative to states that are politically stable.

While the common pool problem inherent in public sector savings permits systematic political manipulation of states' savings, budget stabilization funds provide states' decision-makers with the potential means to lessen the common pool problem by constraining the manner in which public sector funds can be allocated. In short, although legislators may have an incentive to exploit the common pool problem for self-gain, if the benefits to saving the funds are large enough, each legislator may voluntarily agree to constrain their own behavior in exchange for other legislators constraining their behavior 
(Buchanan, 1990). Thus, the adoption of budget stabilization funds may be in response to systematic political manipulation of states' saving.

The determinants of state budget stabilization fund adoption are investigated in Chapter 4. An empirical model is estimated using 46 states over the period from 1945 to 1996 to examine the role that political, economic, fiscal conditions, and fiscal preferences have had on states' choices to adopt stabilization funds. The empirical results presented in Chapter 4 provide evidence consistent with the notion that decision-makers in states with long-run problems of political stability are more likely to adopt stabilization funds as a additional method for saving than politically stable states because the expected gains from saving are larger for politically unstable states. In addition, I also find evidence consistent with a political prisoner's dilemma motive for adopting a stabilization fund since the number of seats in states' upper houses is positively correlated with stabilization fund adoption. Given that legislator incentives to spend inefficiently are increasing with the number of political districts (because an increasing number of districts provides them with increased opportunities to centralize spending and decentralize costs) legislators may place high demands on surplus balances. Since the number of seats in states' upper houses is positively correlated with states' adoption choices, this provides evidence consistent with the notion that the benefits to retaining surplus balances is large enough that states' decision-makers have opted to establish stabilization funds even though they have an incentive to spend any surplus funds.

In addition to political motives, I also find evidence that states hit more severely by recessions are more likely to adopt budget stabilization funds, which may explain a fraction of the large increase in stabilization fund adoptions immediately following the 
1980-1982 recession. Moreover, the empirical results in Chapter 4 indicate that states which have expenditure and tax limitation laws in place are more likely to adopt a stabilization fund. This finding suggests that at least some states adopted stabilization funds to circumvent the fiscal constraints enacted as a result of the 'tax revolt' of the late 1970s and early 1980s. I also find evidence that states which are committed to fiscal discipline and maintaining sound fiscal health are more likely to adopt budget stabilization funds than are states in poor fiscal health.

The final research chapter of the dissertation, Chapter 5, investigates how states' savings behavior has changed since utilizing budget stabilization funds. Since monies retained in budget stabilization funds are typically allocated from states' general fund surpluses, states may not be enhancing their fiscal health by adopting stabilization funds since the balances held in the stabilization fund may be perfectly substitutable with balances held in states' general funds. In short, budget stabilization funds and general funds may be fungible substitutes.

Using unpublished data from each state, an empirical model is estimated in Chapter 5 for each state to examine how each state's average rate of saving and average total balances have changed since adopting a budget stabilization fund. The empirical results reveal that while one-third of the states has experienced significantly higher average total balances after adopting budget stabilization funds, the majority of states' budget stabilization funds are no more than fungible substitutes for states' general funds. That is, only 16 of the 44 states currently utilizing budget stabilization funds have experienced a significant increase in their reserve balances since adopting a stabilization fund. Moreover, I find that nearly all states which have benefited from stabilization funds 
have done so not by increasing the rate at which they save annually, rather they have benefited from retaining the funds they do save longer.

Chapter 5 also estimates an empirical model to explore the role that the structure of states' budget stabilization funds has played in the savings' gains experienced by states since adopting a stabilization fund. The empirical results reveal strong evidence that the structure of states' stabilization funds is extremely influential in determining the gains to savings states have experienced. I find that states whose stabilization funds contain explicit withdrawal and deposit rules are much more likely to experience significant gains in their total balances than are states whose decision-makers have complete discretion governing deposits and withdrawals. Thus while many states have not enhanced their fiscal health, and thus their ability to mitigate recessions, by adopting budget stabilization funds, this does not suggest that stabilization funds are an ineffective means of saving. In fact, the empirical results from Chapter 5 reveal that budget stabilization funds are an effective means of saving, but only when they are structured properly.

While this dissertation has provided insights into several important aspects regarding the savings behavior of state governments, the prospects for future research in this area are bright. For instance, this dissertation adopted a direct approach to investigating the effectiveness of budget stabilization funds by exploring how states' savings behavior has changed since utilizing stabilization funds. However the 'effectiveness' of budget stabilization funds may be measured by different criteria. An indirect approach to examining the 'effectiveness' of stabilization funds would be to examine if states' growth rates in expenditures have remained closer to their long-run averages since adopting stabilization funds. 
In addition, the concept of fiscal stability provides an additional indirect approach to exploring states' savings and budget stabilization funds. Pollock and Suyderhoud (1986) constructed a theoretical index of state fiscal stability based on the state's expenditures, revenue, and their long-run growth rates, and an empirical investigation of the role of savings and budget stabilization funds in achieving greater fiscal stability seems particularly fruitful. While the notion of state fiscal stability can be a rather complex idea, the data provided in this dissertation does provide a point of departure for further investigations into this matter. 


\section{Appendix A}

\section{The Determinants of Public Sector Saving}

To obtain the reduced-form arguments of the legislator's savings function, we may totally differentiate equation (5) and use the fact that $S_{t}=R_{t}-G_{t}(\cdot)$ to sign the corresponding derivatives. For instance, the impact of current fungible assets on current spending is given by:

$$
\frac{\partial G_{t}}{\partial A_{t}}=\frac{\beta P_{t+1}\left(1+r_{t}\right) V_{A A}\left(A_{t+1}, X_{t+1}\right)}{\psi}>0
$$

where $\psi=\theta_{t}^{2} U_{N N}\left(\theta_{t} G_{t}-\gamma_{t} R_{t}\right)+\beta P_{t+1} V_{A A}\left(A_{t+1}, X_{t+1}\right)$. We know from Stokey and Lucas (1989) that $V_{A A}$ is negative due to the concavity of the utility function and the convex constraint (Theorem 4.8, p.81). As a result, $\psi<0$ which in turn implies that $\frac{\partial S_{t}}{\partial A_{t}}<0$

The impact of current interest rates on current spending has an ambiguous sign. The effect is given by:

$$
\frac{\partial G_{t}}{\partial r_{t}}=\frac{\beta P_{t+1} A_{t} V_{A A}\left(A_{t+1}, X_{t+1}\right)}{\psi}<0
$$

Since no theoretical restrictions are placed on the state's current fungible assets $\left(A_{t}\right)$, the impact of current interest rates on current spending can not be conclusively signed. As a result, the sign of $\frac{\partial S_{t}}{\partial r_{t}}$ is also ambiguous. However, it is likely that under a wide range of parameter values current fungible assets will be positive, implying that an increase in current real interest rates will likely increase current spending (by way of the income effect). 
In addition, the effect of current revenue on current spending is conclusively positive, however its impact on savings is positive only when restrictions are placed on the model's parameters. The impact of current revenue on current spending may be written as:

$$
\frac{\partial G_{t}}{\partial R_{t}}=\frac{\theta_{t} \gamma_{t} U_{N N}\left(\theta_{t} G_{t}-\gamma_{t} R_{t}\right)+\beta P_{t+1} V_{A A}\left(A_{t+1}, X_{t+1}\right)}{\psi}>0
$$

$\theta_{t}>\gamma_{t}$ is a sufficient condition to ensure that $\frac{\partial G_{t}}{\partial R_{t}}<1$. If this condition holds we have $\frac{\partial S_{t}}{\partial R_{t}}>0$

The probability that a legislator is reelected and part of the majority party $\left(P_{t+1}\right)$ has a negative effect on current spending and a positive effect on current saving, which can be seen from the following expression:

$$
\frac{\partial G_{t}}{\partial S_{t}}=\frac{\beta V_{A}\left(A_{t+1}, X_{t+1}\right)}{\psi}<0 .
$$

Moreover, using the one period update of equation (6) in conjunction with equation (5) allows us to sign the effect that future revenue has on current spending. Differentiating equation (5) with respect to future revenue $\left(R_{t+1}\right)$ yields:

$$
\frac{\partial G_{t}}{\partial R_{t+1}}=\frac{\beta P_{t+1} V_{A R_{t+1}}\left(A_{t+1}, X_{t+1}\right)}{\psi}>0
$$

The sign of $V_{A R_{t+1}}\left(A_{t+1}, X_{t+1}\right)$ can be found by differentiating the one period update of equation (6) with respect to future revenue, recalling that $R_{t+1}$ does not belong to $X_{t+2}$. Thus, $V_{A R_{t+1}}\left(A_{t+1}, X_{t+1}\right)=\beta P_{t+2}\left(1+r_{t+1}\right) V_{A A}\left(A_{t+2}, X_{t+2}\right)<0$ which implies that 
$\frac{\partial S_{t}}{\partial R_{t+1}}<0$. Hence, expectations of higher future revenue suppresses current savings in favor of current spending. Comparative statics for future revenue extending beyond period $t+1$ can be determined in a similar manner.

Finally, differentiating equation (5) with respect to future interest rates yields an ambiguous effect which is given by:

$$
\frac{\partial G_{t}}{\partial r_{t+1}}=\frac{\beta P_{t+1} V_{A r_{t+1}}\left(A_{t+1}, X_{t+1}\right)}{\psi} \leq 0
$$

Differentiating the one period update of equation (6) with respect to future interest rates $\left(r_{t+1}\right)$ gives us $V_{A r_{t+1}}\left(A_{t+1}, X_{t+1}\right)=\beta P_{t+2}\left[V_{A}\left(A_{t+2}, X_{t+2}\right)+\left(1+r_{t+1}\right) A_{t+1} V_{A A}\left(A_{t+2}, X_{t+2}\right)\right]$, which can not be conclusively signed. 


\section{Appendix B}

Since there was little variation in the estimates of first-order serial correlation between the one and two period future model, only the one period results are presented.

Table B1 - Cochrane-Orcutt Estimates of First-Order Serial Correlation Within Individual States

\begin{tabular}{|c|c|c|c|}
\hline State & Estimates of $\hat{\rho}$ & State & Estimates of $\hat{\rho}$ \\
\hline Alaska & 0.22 & New Hampshire & 0.67 \\
\hline Alabama & 0.51 & New Jersey & 0.77 \\
\hline California & 0.54 & New Mexico & 0.67 \\
\hline Colorado & 0.77 & Nevada & 0.59 \\
\hline Delaware & 0.53 & New York & 0.82 \\
\hline Florida & 0.45 & Ohio & 0.83 \\
\hline Georgia & 0.45 & Oklahoma & 0.60 \\
\hline Hawaii & 0.92 & Oregon & 0.48 \\
\hline Illinois & 0.75 & Pennsylvania & 0.62 \\
\hline Kentucky & 0.69 & Rhode Island & 0.73 \\
\hline Louisiana & 0.44 & South Carolina & 0.57 \\
\hline Massachusetts & 0.85 & Tennessee & 0.50 \\
\hline Maryland & 0.87 & Texas & 0.75 \\
\hline Maine & 0.51 & Utah & 0.70 \\
\hline Michigan & 0.29 & Virginia & 0.67 \\
\hline Missouri & 0.70 & Vermont & 0.85 \\
\hline Mississippi & 0.88 & Washington & 0.27 \\
\hline Montana & 0.21 & Wisconsin & 0.50 \\
\hline North Carolina & 0.77 & West Virginia & 0.74 \\
\hline North Dakota & 0.84 & & \\
\hline
\end{tabular}


Appendix C: Stationarity Test Results and ARMA Specifications

Table C1 - Stationarity Tests on States' Savings Rate Prior to BSF-Adoption

\begin{tabular}{|c|c|c|c|c|c|}
\hline State & $\begin{array}{c}\text { ADF Statistic } \\
\text { (level) }\end{array}$ & State & $\begin{array}{c}\text { ADF Statistic } \\
\text { (level) }\end{array}$ & State & $\begin{array}{c}\text { ADF Statistic } \\
\text { (level) }\end{array}$ \\
\hline AK & $\begin{array}{c}-6.396^{* * *} \\
(0)\end{array}$ & MD & $\begin{array}{c}-6.253^{* * *} \\
(0)\end{array}$ & OK & $\begin{array}{c}-5.655^{* * *} \\
(1)\end{array}$ \\
\hline $\mathrm{AZ}$ & $\begin{array}{c}-8.833^{* * *} \\
(0)\end{array}$ & $\mathrm{ME}$ & $\begin{array}{c}-7.197^{* * *} \\
(0)\end{array}$ & PA & $\begin{array}{c}-6.566^{* * *} \\
(1)\end{array}$ \\
\hline $\mathrm{CA}$ & $\begin{array}{c}-6.716^{* * *} \\
(0)\end{array}$ & MI & $\begin{array}{c}-5.801^{* * *} \\
(1)\end{array}$ & $\mathrm{RI}$ & $\begin{array}{c}-8.489^{* * *} \\
(0)\end{array}$ \\
\hline $\mathrm{CO}$ & $\begin{array}{c}-6.642^{* * *} \\
(2)\end{array}$ & $\mathrm{MN}$ & $\begin{array}{c}-5.818^{* * *} \\
(1)\end{array}$ & $\mathrm{SC}$ & $\begin{array}{c}-5.332^{* * *} \\
(2)\end{array}$ \\
\hline $\mathrm{CT}$ & $\begin{array}{c}-4.662^{* * *} \\
\text { (1) }\end{array}$ & MO & $\begin{array}{c}-6.249^{* * *} \\
(3)\end{array}$ & SD & $\begin{array}{c}-9.493^{* * *} \\
(0)\end{array}$ \\
\hline $\mathrm{DE}$ & $\begin{array}{c}-5.790^{* * *} \\
(0)\end{array}$ & MS & $\begin{array}{c}-8.841^{* * *} \\
(0)\end{array}$ & $\mathrm{TN}$ & $\begin{array}{c}-4.923^{* * *} \\
(0)\end{array}$ \\
\hline FL & $\begin{array}{c}-7.241^{* * *} \\
(0)\end{array}$ & $\mathrm{NC}$ & $\begin{array}{c}-10.228^{* * * *} \\
(0)\end{array}$ & $\mathrm{TX}$ & $\begin{array}{c}-7.021^{* * *} \\
(0)\end{array}$ \\
\hline GA & $\begin{array}{c}-5.937^{* * *} \\
(0)\end{array}$ & ND & $\begin{array}{c}-6.270^{* * *} \\
(1)^{* * *}\end{array}$ & UT & $\begin{array}{c}-9.393^{* * *} \\
(0)\end{array}$ \\
\hline IA & $\begin{array}{c}-6.424^{* * *} \\
\text { (1) }\end{array}$ & $\mathrm{NE}$ & $\begin{array}{c}-6.366^{* * *} \\
(2)\end{array}$ & VA & $\begin{array}{c}-6.813^{* * *} \\
(2)\end{array}$ \\
\hline ID & $\begin{array}{c}-7.197^{* * *} \\
(0)\end{array}$ & $\mathrm{NH}$ & $\begin{array}{c}-7.520^{* * *} \\
(0)\end{array}$ & VT & $\begin{array}{c}-6.073^{* * *} \\
(1)\end{array}$ \\
\hline IN & $\begin{array}{c}-6.331^{* * *} \\
(0)\end{array}$ & $\mathrm{NJ}$ & $\begin{array}{c}-9.251^{* * *} \\
(0)\end{array}$ & WA & $\begin{array}{c}-4.303^{* * *} \\
(4)\end{array}$ \\
\hline KY & $\begin{array}{c}-8.149^{* * *} \\
(0)\end{array}$ & NM & $\begin{array}{c}-6.971^{* * *} \\
(0)\end{array}$ & WI & $\begin{array}{c}-5.869^{* * *} \\
(1)\end{array}$ \\
\hline $\mathrm{KS}$ & $\begin{array}{c}-5.989^{* * *} \\
(1)\end{array}$ & NY & $\begin{array}{c}-5.213^{* * *} \\
(1)\end{array}$ & WV & $\begin{array}{c}-10.642^{* * * *} \\
(0)\end{array}$ \\
\hline LA & $\begin{array}{c}-9.142^{* * *} \\
(0)\end{array}$ & NV & $\begin{array}{c}-9.164^{* * *} \\
(0)\end{array}$ & WY & $\begin{array}{c}-8.029^{* * *} \\
(0)\end{array}$ \\
\hline MA & $\begin{array}{c}-8.119^{* * *} \\
(1) \\
\end{array}$ & $\mathrm{OH}$ & $\begin{array}{c}-6.054^{* * *} \\
(0)\end{array}$ & & \\
\hline
\end{tabular}

Notes: Model lag lengths are in parentheses below ADF Statistics and were selected according to Akaike's Information Criterion (AIC). Significance levels are from Mackinnon (1991) and are denoted as follows: ${ }^{* * *}$ denotes significance at the 1 percent level, ${ }^{* *}$ at the 5 percent level, and ${ }^{*}$ at the 10 percent level. Tests included both a constant term and linear trend. 
Table C2 - Stationarity Tests on States' Total Balances Prior to BSF-Adoption

\begin{tabular}{|c|c|c|c|c|c|c|c|c|}
\hline State & $\begin{array}{c}\text { ADF } \\
\text { Statistic } \\
\text { (level) } \\
\end{array}$ & $\begin{array}{c}\text { ADF } \\
\text { Statistic } \\
(\Delta) \\
\end{array}$ & State & $\begin{array}{c}\text { ADF } \\
\text { Statistic } \\
\text { (level) }\end{array}$ & $\begin{array}{c}\text { ADF } \\
\text { Statistic } \\
(\Delta) \\
\end{array}$ & State & $\begin{array}{c}\text { ADF } \\
\text { Statistic } \\
\text { (level) }\end{array}$ & $\begin{array}{c}\text { ADF } \\
\text { Statistic } \\
(\Delta)\end{array}$ \\
\hline AK & $\begin{array}{c}-2.577 \\
(2)\end{array}$ & $\begin{array}{c}-3.454^{*} \\
(2)\end{array}$ & MD & $\begin{array}{c}-1.495 \\
(0)\end{array}$ & $\begin{array}{c}-5.944^{* * *} \\
(1)\end{array}$ & OK & $\begin{array}{c}-2.249 \\
(0)\end{array}$ & $\begin{array}{c}-7.486^{* * *} \\
\text { (1) }\end{array}$ \\
\hline $\mathrm{AZ}$ & $\begin{array}{c}-2.419 \\
(0)\end{array}$ & $\begin{array}{c}-4.189^{* * *} \\
(4)\end{array}$ & $\mathrm{ME}$ & $\begin{array}{c}-4.295^{* * * *} \\
(0)\end{array}$ & -- & PA & $\begin{array}{c}-3.196^{*} \\
(1)\end{array}$ & -- \\
\hline $\mathrm{CA}$ & $\begin{array}{c}-4.080^{* *} \\
(0)\end{array}$ & -- & MI & $\begin{array}{c}-4.077^{* *} \\
(1)\end{array}$ & -- & RI & $\begin{array}{c}-2.741 \\
(0)\end{array}$ & $\begin{array}{c}-6.422^{* * *} \\
(0)\end{array}$ \\
\hline $\mathrm{CO}$ & $\begin{array}{c}-5.999^{* * *} \\
(1)\end{array}$ & -- & $\mathrm{MN}$ & $\begin{array}{c}-4.599^{* * *} \\
(1)\end{array}$ & -- & $\mathrm{SC}$ & $\begin{array}{c}-3.651^{* *} \\
(1)\end{array}$ & -- \\
\hline $\mathrm{CT}$ & $\begin{array}{c}-3.763^{* *} \\
(1)\end{array}$ & -- & MO & $\begin{array}{c}-5.112^{* * *} \\
(2)\end{array}$ & -- & SD & $\begin{array}{c}-5.063^{* * *} \\
(2)\end{array}$ & -- \\
\hline $\mathrm{DE}$ & $\begin{array}{c}-3.784^{* * *} \\
(0)\end{array}$ & -- & MS & $\begin{array}{c}-4.917^{* * * *} \\
(0)\end{array}$ & -- & $\mathrm{TN}$ & $\begin{array}{c}-2.024 \\
(2)\end{array}$ & $\begin{array}{c}-5.093^{* * *} \\
(0)\end{array}$ \\
\hline FL & $\begin{array}{c}-3.350^{*} \\
(0)\end{array}$ & -- & $\mathrm{NC}$ & $\begin{array}{c}-3.646^{* *} \\
(0)\end{array}$ & -- & $\mathrm{TX}$ & $\begin{array}{c}-3.368^{* *} \\
(1)\end{array}$ & -- \\
\hline GA & $\begin{array}{c}-3.000 \\
(0)\end{array}$ & $\begin{array}{c}-6.218^{* * *} \\
(1)\end{array}$ & ND & $\begin{array}{c}-3.357^{*} \\
(0)\end{array}$ & -- & UT & $\begin{array}{c}-4.328^{* * * *} \\
(0)\end{array}$ & -- \\
\hline IA & $\begin{array}{c}-4.022^{* *} \\
\text { (1) }\end{array}$ & -- & $\mathrm{NE}$ & $\begin{array}{c}-5.099^{* * *} \\
(1)\end{array}$ & -- & VA & $\begin{array}{c}-4.343^{* * * *} \\
(1)\end{array}$ & -- \\
\hline ID & $\begin{array}{c}-5.048^{* * *} \\
(1)\end{array}$ & -- & $\mathrm{NH}$ & $\begin{array}{c}-1.315 \\
(0)\end{array}$ & $\begin{array}{c}-6.079^{* * * *} \\
(1)\end{array}$ & VT & $\begin{array}{c}-2.202 \\
(1)\end{array}$ & $\begin{array}{c}-6.306^{* * *} \\
\text { (1) }\end{array}$ \\
\hline IN & $\begin{array}{c}-3.862^{* *} \\
(0)\end{array}$ & -- & NJ & $\begin{array}{c}-2.734 \\
(0)\end{array}$ & $\begin{array}{c}-7.144^{* * *} \\
(0)\end{array}$ & WA & $\begin{array}{c}-4.376^{* * *} \\
(0)\end{array}$ & - \\
\hline KY & $\begin{array}{c}-3.257^{*} \\
(0)\end{array}$ & -- & NM & $\begin{array}{c}-4.278^{* *} \\
\text { (1) }\end{array}$ & -- & WI & $\begin{array}{c}-4.030^{* *} \\
(1)\end{array}$ & -- \\
\hline KS & $\begin{array}{c}-4.012^{* *} \\
(1)\end{array}$ & -- & NY & $\begin{array}{c}-3.791^{*} \\
(2)\end{array}$ & -- & WV & $\begin{array}{c}-3.942^{* *} \\
(2)\end{array}$ & -- \\
\hline LA & $\begin{array}{c}-5.489^{* * *} \\
(1)\end{array}$ & -- & NV & $\begin{array}{c}-3.992^{* *} \\
(0)\end{array}$ & -- & WY & $\begin{array}{c}-0.949 \\
(2)\end{array}$ & $\begin{array}{c}-5.011^{* * *} \\
(2)\end{array}$ \\
\hline MA & $\begin{array}{c}-4.193^{* *} \\
(0) \\
\end{array}$ & -- & $\mathrm{OH}$ & $\begin{array}{c}-2.469 \\
(0) \\
\end{array}$ & $\begin{array}{c}-5.686^{* * *} \\
(0) \\
\end{array}$ & & & \\
\hline
\end{tabular}

Notes: Model lag lengths are in parentheses below ADF Statistics and were selected according to Akaike's Information Criterion (AIC). Significance levels are from Mackinnon (1991) and are denoted as follows: ${ }^{* * * *}$ denotes significance at the 1 percent level, ${ }^{* *}$ at the 5 percent level, and ${ }^{*}$ at the 10 percent level. Tests included a constant and a linear trend. 
Table C3 - ARMA Specifications of Intervention Models

\begin{tabular}{|c|c|c|c|c|c|}
\hline State & Savings Rate Model & $\begin{array}{c}\text { Total Balances } \\
\text { Model }\end{array}$ & State & $\begin{array}{c}\text { Savings Rate } \\
\text { Model }\end{array}$ & $\begin{array}{c}\text { Total Balance } \\
\text { Model }\end{array}$ \\
\hline AK & $\operatorname{ARMA}(0,0)$ & $\operatorname{ARMA}(0,0)$ & ND & $\operatorname{ARMA}(0,2)$ & $\operatorname{ARMA}(1,0)$ \\
\hline $\mathrm{AZ}$ & $\operatorname{ARMA}(0,0)$ & $\operatorname{ARMA}(0,0)$ & $\mathrm{NE}$ & $\operatorname{ARMA}(0,2)$ & $\operatorname{ARMA}(0,1)$ \\
\hline CA & $\operatorname{ARMA}(0,0)$ & $\operatorname{ARMA}(3,0)$ & $\mathrm{NH}$ & $\operatorname{ARMA}(0,0)$ & $\operatorname{ARMA}(1,0)$ \\
\hline $\mathrm{CO}$ & $\operatorname{ARMA}(2,0)$ & $\operatorname{ARMA}(0,0)$ & $\mathrm{NJ}$ & $\operatorname{ARMA}(1,0)$ & $\operatorname{ARMA}(0,0)$ \\
\hline CT & $\operatorname{ARMA}(0,1)$ & $\operatorname{ARMA}(2,0)$ & NM & $\operatorname{ARMA}(0,1)$ & $\operatorname{ARMA}(1,0)$ \\
\hline DE & $\operatorname{ARMA}(0,0)$ & $\operatorname{ARMA}(1,0)$ & NY & $\operatorname{ARMA}(0,1)$ & $\operatorname{ARMA}(0,1)$ \\
\hline FL & $\operatorname{ARMA}(1,0)$ & $\operatorname{ARMA}(1,0)$ & $\mathrm{NV}$ & $\operatorname{ARMA}(1,0)$ & $\operatorname{ARMA}(1,0)$ \\
\hline GA & $\operatorname{ARMA}(0,0)$ & $\operatorname{ARMA}(1,0)$ & $\mathrm{OH}$ & $\operatorname{ARMA}(0,0)$ & $\operatorname{ARMA}(0,0)$ \\
\hline IA & $\operatorname{ARMA}(2,0)$ & $\operatorname{ARMA}(1,0)$ & OK & $\operatorname{ARMA}(0,2)$ & $\operatorname{ARMA}(2,0)$ \\
\hline ID & $\operatorname{ARMA}(2,0)$ & $\operatorname{ARMA}(2,0)$ & PA & $\operatorname{ARMA}(2,0)$ & $\operatorname{ARMA}(1,1)$ \\
\hline IN & $\operatorname{ARMA}(1,0)$ & $\operatorname{ARMA}(0,1)$ & RI & $\operatorname{ARMA}(0,0)$ & $\operatorname{ARMA}(0,0)$ \\
\hline KS & $\operatorname{ARMA}(0,0)$ & $\operatorname{ARMA}(1,1)$ & $\mathrm{SC}$ & $\operatorname{ARMA}(0,0)$ & $\operatorname{ARMA}(2,0)$ \\
\hline KY & $\operatorname{ARMA}(0,1)$ & $\operatorname{ARMA}(1,0)$ & SD & $\operatorname{ARMA}(0,2)$ & $\operatorname{ARMA}(0,0)$ \\
\hline LA & $\operatorname{ARMA}(1,0)$ & $\operatorname{ARMA}(1,0)$ & $\mathrm{TN}$ & $\operatorname{ARMA}(2,0)$ & $\operatorname{ARMA}(0,0)$ \\
\hline MA & $\operatorname{ARMA}(2,0)$ & $\operatorname{ARMA}(1,0)$ & $\mathrm{TX}$ & $\operatorname{ARMA}(0,0)$ & $\operatorname{ARMA}(1,0)$ \\
\hline MD & $\operatorname{ARMA}(0,0)$ & $\operatorname{ARMA}(0,0)$ & UT & $\operatorname{ARMA}(1,0)$ & $\operatorname{ARMA}(1,0)$ \\
\hline ME & $\operatorname{ARMA}(0,2)$ & $\operatorname{ARMA}(1,1)$ & VA & $\operatorname{ARMA}(0,1)$ & $\operatorname{ARMA}(1,0)$ \\
\hline MI & $\operatorname{ARMA}(0,0)$ & $\operatorname{ARMA}(0,1)$ & VT & $\operatorname{ARMA}(1,0)$ & $\operatorname{ARMA}(2,0)$ \\
\hline $\mathrm{MN}$ & $\operatorname{ARMA}(0,0)$ & $\operatorname{ARMA}(2,0)$ & WA & $\operatorname{ARMA}(3,0)$ & $\operatorname{ARMA}(1,0)$ \\
\hline MO & $\operatorname{ARMA}(0,0)$ & $\operatorname{ARMA}(2,0)$ & WI & $\operatorname{ARMA}(0,1)$ & $\operatorname{ARMA}(0,1)$ \\
\hline MS & $\operatorname{ARMA}(0,0)$ & $\operatorname{ARMA}(0,0)$ & WV & $\operatorname{ARMA}(1,0)$ & $\operatorname{ARMA}(1,0)$ \\
\hline $\mathrm{NC}$ & $\operatorname{ARMA}(0,0)$ & $\operatorname{ARMA}(0,1)$ & WY & $\operatorname{ARMA}(1,0)$ & $\operatorname{ARMA}(1,0)$ \\
\hline
\end{tabular}

Notes: Total balance models of CO, NM, and TX also included a linear time trend. 


\section{Appendix D: Maximum Likelihood Estimates of Intervention Models}

Table D1 - Maximum Likelihood Estimates of Savings Rate Model

\begin{tabular}{|c|c|c|c|c|c|c|c|c|c|}
\hline \multirow[b]{2}{*}{ State } & \multicolumn{2}{|c|}{$\begin{array}{c}\text { Adoption } \\
\text { Intervention }\end{array}$} & \multicolumn{2}{|c|}{$\begin{array}{l}\text { First Balance } \\
\text { Intervention }\end{array}$} & \multirow[b]{2}{*}{ State } & \multicolumn{2}{|c|}{$\begin{array}{c}\text { Adoption } \\
\text { Intervention }\end{array}$} & \multicolumn{2}{|c|}{$\begin{array}{c}\text { First Balance } \\
\text { Intervention } \\
\end{array}$} \\
\hline & $\begin{array}{l}\text { Initial } \\
\text { Impact }\end{array}$ & Decay & $\begin{array}{l}\text { Initial } \\
\text { Impact }\end{array}$ & Decay & & $\begin{array}{l}\text { Initial } \\
\text { Impact }\end{array}$ & Decay & $\begin{array}{l}\text { Initial } \\
\text { Impact }\end{array}$ & Decay \\
\hline AK & $\begin{array}{c}4.617 \\
(19.145)\end{array}$ & -- & $\begin{array}{c}3.493 \\
(24.379)\end{array}$ & -- & ND & $\begin{array}{l}-0.392 \\
(3.603)\end{array}$ & -- & $\begin{array}{c}2.428 \\
(4.827)\end{array}$ & -- \\
\hline $\mathrm{AZ}$ & $\begin{array}{c}1.200 \\
(2.746)\end{array}$ & -- & $\begin{array}{l}-0.375 \\
(4.016)\end{array}$ & -- & $\mathrm{NE}$ & $\begin{array}{l}-3.186 \\
(2.936)\end{array}$ & -- & $\begin{array}{c}6.420 \\
(5.339)\end{array}$ & $\begin{array}{c}-0.899^{* * *} \\
(0.170)\end{array}$ \\
\hline $\mathrm{CA}$ & $\begin{array}{c}2.423 \\
(6.666)\end{array}$ & -- & $\begin{array}{l}-1.951 \\
(6.719)\end{array}$ & -- & $\mathrm{NH}$ & -- & -- & $\begin{array}{l}-0.607 \\
(2.230)\end{array}$ & -- \\
\hline $\mathrm{CO}$ & $\begin{array}{l}-5.546 \\
(4.010)\end{array}$ & -- & $\begin{array}{c}6.706 \\
(4.122)\end{array}$ & -- & $\mathrm{NJ}$ & $\begin{array}{l}-1.193 \\
(5.336)\end{array}$ & -- & $\begin{array}{c}2.280 \\
(6.999)\end{array}$ & -- \\
\hline CT & $\begin{array}{c}1.648 \\
(6.211)\end{array}$ & -- & $\begin{array}{l}-0.456 \\
(6.781)\end{array}$ & -- & NM & $\begin{array}{l}-2.863 \\
(5.529)\end{array}$ & -- & $\begin{array}{c}2.648 \\
(5.515)\end{array}$ & -- \\
\hline $\mathrm{DE}$ & -- & -- & $\begin{array}{c}3.617 \\
(3.552)\end{array}$ & -- & NY & $\begin{array}{l}-1.324 \\
(1.459)\end{array}$ & -- & $\begin{array}{c}1.127 \\
(2.318)\end{array}$ & -- \\
\hline FL & $\begin{array}{c}2.904 \\
(2.458)\end{array}$ & -- & $\begin{array}{l}-2.007 \\
(2.325)\end{array}$ & -- & NV & -- & -- & $\begin{array}{c}2.738 \\
(3.032)\end{array}$ & -- \\
\hline GA & -- & -- & $\begin{array}{c}0.270 \\
(1.485)\end{array}$ & -- & $\mathrm{OH}$ & $\begin{array}{c}2.361 \\
(2.821)\end{array}$ & -- & $\begin{array}{l}-1.521 \\
(3.086)\end{array}$ & -- \\
\hline IA & $\begin{array}{c}0.635 \\
(2.076)\end{array}$ & -- & $\begin{array}{l}1.139 \\
(3.265)\end{array}$ & -- & OK & $\begin{array}{l}-3.024 \\
(2.812)\end{array}$ & $\begin{array}{c}-0.951^{* * *} \\
(0.185)\end{array}$ & $\begin{array}{c}1.317 \\
(1.959)\end{array}$ & -- \\
\hline ID & -- & -- & $\begin{array}{c}1.184 \\
(0.929)\end{array}$ & -- & PA & $\begin{array}{l}-0.433 \\
(7.592)\end{array}$ & -- & $\begin{array}{l}-0.257 \\
(7.856)\end{array}$ & -- \\
\hline IN & $\begin{array}{c}3.756 \\
(4.084)\end{array}$ & -- & $\begin{array}{l}-2.441 \\
(7.247)\end{array}$ & $\begin{array}{c}0.275 \\
(1.956)\end{array}$ & RI & -- & -- & $\begin{array}{c}0.132 \\
(2.897)\end{array}$ & -- \\
\hline $\mathrm{KS}$ & -- & -- & $\begin{array}{c}1.426 \\
(3.404)\end{array}$ & -- & $\mathrm{SC}$ & -- & -- & $\begin{array}{c}0.317 \\
(1.809)\end{array}$ & -- \\
\hline KY & -- & -- & $\begin{array}{l}1.460^{*} \\
(0.801)\end{array}$ & -- & SD & $\begin{array}{c}5.890 \\
(7.892)\end{array}$ & -- & $\begin{array}{l}-5.892 \\
(9.467)\end{array}$ & -- \\
\hline LA & $\begin{array}{l}-1.583 \\
(1.682)\end{array}$ & -- & -- & -- & $\mathrm{TN}$ & -- & -- & $\begin{array}{c}0.050 \\
(0.981)\end{array}$ & -- \\
\hline MA & $\begin{array}{c}1.232 \\
(6.551)\end{array}$ & -- & $\begin{array}{c}-2.291 \\
(10.008)\end{array}$ & $\begin{array}{l}-0.545 \\
(3.140)\end{array}$ & TX & $\begin{array}{c}0.293 \\
(2.482)\end{array}$ & -- & $\begin{array}{l}-0.910 \\
(2.863)\end{array}$ & -- \\
\hline MD & $\begin{array}{l}-1.379 \\
(5.564)\end{array}$ & -- & $\begin{array}{c}1.645 \\
(5.764)\end{array}$ & -- & UT & $\begin{array}{l}-4.482 \\
(5.239)\end{array}$ & -- & $\begin{array}{c}5.503 \\
(5.438)\end{array}$ & -- \\
\hline $\mathrm{ME}$ & -- & -- & $\begin{array}{l}-0.063 \\
(1.004)\end{array}$ & -- & VA & $\begin{array}{c}1.917 \\
(2.323)\end{array}$ & -- & $\begin{array}{l}-2.509 \\
(4.533)\end{array}$ & -- \\
\hline MI & $\begin{array}{c}5.989 \\
(5.060)\end{array}$ & -- & $\begin{array}{l}-9.268 \\
(8.109)\end{array}$ & $\begin{array}{c}-0.821^{* * *} \\
(0.241)\end{array}$ & VT & -- & -- & $\begin{array}{l}-0.399 \\
(2.296)\end{array}$ & -- \\
\hline $\mathrm{MN}$ & $\begin{array}{c}0.307 \\
(4.740)\end{array}$ & -- & $\begin{array}{c}0.063 \\
(5.047)\end{array}$ & -- & WA & $\begin{array}{c}0.476 \\
(1.839)\end{array}$ & -- & $\begin{array}{l}-0.848 \\
(2.429)\end{array}$ & -- \\
\hline MO & -- & -- & $\begin{array}{c}1.861 \\
(2.422)\end{array}$ & -- & WI & - & -- & $\begin{array}{c}0.734 \\
(0.892)\end{array}$ & -- \\
\hline MS & $\begin{array}{c}2.731 \\
(5.656)\end{array}$ & -- & $\begin{array}{l}-1.851 \\
(5.774)\end{array}$ & -- & WV & $\begin{array}{l}-1.420 \\
(8.207)\end{array}$ & -- & $\begin{array}{c}3.008 \\
(10.496)\end{array}$ & -- \\
\hline $\mathrm{NC}$ & -- & -- & $\begin{array}{c}0.838 \\
(3.278) \\
\end{array}$ & -- & WY & $\begin{array}{c}15.247^{* *} \\
(6.416) \\
\end{array}$ & -- & $\begin{array}{c}-16.86^{* * *} \\
(6.555) \\
\end{array}$ & -- \\
\hline
\end{tabular}

Notes: Standard errors in parentheses. Asymptotic impacts of intervention terms are included in Tables 5.3 and 5.4 in Chapter 5. The year of BSF adoption and first balance were the same for DE, GA, ID, KY, ME, MO, NC, NH, NV, RI, SC, TN, VT, and WI. 
Table D2 - Maximum Likelihood Estimates of Total Balances Model

\begin{tabular}{|c|c|c|c|c|c|c|c|c|c|}
\hline \multirow[b]{2}{*}{ State } & \multicolumn{2}{|c|}{$\begin{array}{c}\text { Adoption } \\
\text { Intervention }\end{array}$} & \multicolumn{2}{|c|}{$\begin{array}{l}\text { First Balance } \\
\text { Intervention }\end{array}$} & \multirow[b]{2}{*}{ State } & \multicolumn{2}{|c|}{$\begin{array}{c}\text { Adoption } \\
\text { Intervention }\end{array}$} & \multicolumn{2}{|c|}{$\begin{array}{c}\text { First Balance } \\
\text { Intervention }\end{array}$} \\
\hline & $\begin{array}{l}\text { Initial } \\
\text { Impact }\end{array}$ & Decay & $\begin{array}{l}\text { Initial } \\
\text { Impact }\end{array}$ & Decay & & $\begin{array}{l}\text { Initial } \\
\text { Impact }\end{array}$ & Decay & $\begin{array}{c}\text { Initial } \\
\text { Impact }\end{array}$ & Decay \\
\hline $\mathrm{AK}$ & $\begin{array}{l}888.234 \\
(1243.2)\end{array}$ & -- & $\begin{array}{c}624.050 \\
(1234.0)\end{array}$ & -- & ND & $\begin{array}{c}-56.360 \\
(54.266)\end{array}$ & -- & $\begin{array}{l}130.88^{* * *} \\
(57.847)\end{array}$ & -- \\
\hline $\mathrm{AZ}$ & $\begin{array}{l}-227.202 \\
(227.64)\end{array}$ & -- & $\begin{array}{l}184.053 \\
(227.64)\end{array}$ & -- & $\mathrm{NE}$ & $\begin{array}{l}-11.280 \\
(38.670)\end{array}$ & -- & $\begin{array}{l}149.15^{* * * *} \\
(53.867)\end{array}$ & $\begin{array}{c}-0.812^{* * *} \\
(0.103)\end{array}$ \\
\hline CA & $\begin{array}{l}-1981.85 \\
(1880.9)\end{array}$ & -- & $\begin{array}{c}3145.9 \\
(1852.9)\end{array}$ & -- & $\mathrm{NH}$ & -- & -- & $\begin{array}{l}-23.016 \\
(14.224)\end{array}$ & -- \\
\hline $\mathrm{CO}$ & $\begin{array}{l}-366.79^{*} \\
(208.91)\end{array}$ & -- & $\begin{array}{l}462.27^{* *} \\
(206.93)\end{array}$ & -- & $\mathrm{NJ}$ & $\begin{array}{l}-474.97 \\
(592.35)\end{array}$ & -- & $\begin{array}{c}917.97 \\
(592.35)\end{array}$ & -- \\
\hline CT & $\begin{array}{l}434.507 \\
(263.09)\end{array}$ & -- & $\begin{array}{l}210.068 \\
(279.41)\end{array}$ & -- & NM & $\begin{array}{c}38.627 \\
(126.16)\end{array}$ & -- & $\begin{array}{c}47.041 \\
(126.51)\end{array}$ & -- \\
\hline DE & -- & -- & $\begin{array}{c}79.423^{* * *} \\
(26.044)\end{array}$ & $\begin{array}{c}0.806^{* * * *} \\
(0.078)\end{array}$ & NY & $\begin{array}{l}451.708 \\
(378.32)\end{array}$ & -- & $\begin{array}{l}-115.870 \\
(99.684)\end{array}$ & -- \\
\hline FL & $\begin{array}{l}167.591 \\
(248.86)\end{array}$ & -- & $\begin{array}{l}-120.251 \\
(237.49)\end{array}$ & -- & NV & -- & -- & $\begin{array}{l}139.69^{* * * *} \\
(49.614)\end{array}$ & -- \\
\hline GA & -- & -- & $\begin{array}{l}318.096 \\
(242.97)\end{array}$ & -- & $\mathrm{OH}$ & $\begin{array}{c}58.976 \\
(441.51)\end{array}$ & -- & $\begin{array}{l}828.421 \\
(441.51)\end{array}$ & -- \\
\hline IA & $\begin{array}{l}-14.036 \\
(95.983)\end{array}$ & -- & $\begin{array}{c}155.091 \\
(120.76)\end{array}$ & -- & OK & $\begin{array}{l}-371.6^{* * * *} \\
(143.44)\end{array}$ & -- & $\begin{array}{l}344.71^{* * *} \\
(140.89)\end{array}$ & -- \\
\hline ID & -- & -- & $\begin{array}{c}20.434^{* * *} \\
(5.005)\end{array}$ & $\begin{array}{c}0.995^{* * *} \\
(0.051)\end{array}$ & PA & $\begin{array}{c}355.98 \\
(728.78)\end{array}$ & -- & $\begin{array}{c}194.72 \\
(732.94)\end{array}$ & -- \\
\hline IN & $\begin{array}{l}175.736 \\
(209.68)\end{array}$ & -- & $\begin{array}{l}448.96^{*} \\
(224.50)\end{array}$ & -- & RI & -- & -- & $\begin{array}{c}32.140 \\
(119.17)\end{array}$ & -- \\
\hline KS & & -- & $\begin{array}{c}189.231 \\
(137.45)\end{array}$ & -- & $\mathrm{SC}$ & -- & -- & $\begin{array}{c}127.193 \\
(110.38)\end{array}$ & -- \\
\hline KY & -- & -- & $\begin{array}{l}305.71^{* *} \\
(152.18)\end{array}$ & -- & SD & $\begin{array}{c}63.984 \\
(51.906)\end{array}$ & -- & $\begin{array}{l}-33.800 \\
(56.238)\end{array}$ & -- \\
\hline LA & $\begin{array}{c}-338.49^{* * *} \\
(150.68)\end{array}$ & -- & -- & -- & $\mathrm{TN}$ & -- & -- & $\begin{array}{l}457.55^{*} \\
(231.16)\end{array}$ & -- \\
\hline MA & $\begin{array}{l}650.925 \\
(421.09)\end{array}$ & -- & $\begin{array}{l}-579.003 \\
(431.45)\end{array}$ & -- & $\mathrm{TX}$ & $\begin{array}{l}-980.14^{* * *} \\
(460.25)\end{array}$ & -- & $\begin{array}{c}4.674 \\
(462.20)\end{array}$ & -- \\
\hline MD & $\begin{array}{l}-169.725 \\
(285.88)\end{array}$ & -- & $\begin{array}{l}129.177 \\
(285.88)\end{array}$ & -- & UT & $\begin{array}{c}-49.739 \\
(71.739)\end{array}$ & -- & $\begin{array}{l}130.79^{*} \\
(74.29)\end{array}$ & -- \\
\hline ME & -- & -- & $\begin{array}{l}111.42^{* *} \\
(54.871)\end{array}$ & -- & VA & $\begin{array}{l}370.33^{* *} \\
(148.60)\end{array}$ & -- & $\begin{array}{c}39.423 \\
(179.95)\end{array}$ & -- \\
\hline MI & $\begin{array}{l}913.90^{*} \\
(522.51)\end{array}$ & -- & $\begin{array}{c}75.793 \\
(528.80)\end{array}$ & -- & VT & -- & -- & $\begin{array}{l}-43.318 \\
(30.348)\end{array}$ & $\begin{array}{c}0.591 \\
(0.366)\end{array}$ \\
\hline MN & $\begin{array}{l}467.52^{* * *} \\
(176.46)\end{array}$ & $\begin{array}{c}-0.782^{* *} \\
(0.135)\end{array}$ & $\begin{array}{c}512.08^{* * * *} \\
(140.48)\end{array}$ & -- & WA & $\begin{array}{l}-205.521 \\
(178.64)\end{array}$ & -- & $\begin{array}{l}-54.303 \\
(217.85)\end{array}$ & -- \\
\hline MO & -- & -- & $\begin{array}{l}283.30^{* *} \\
(117.35)\end{array}$ & $\begin{array}{c}0.841^{* * * *} \\
(0.263)\end{array}$ & WI & -- & -- & $\begin{array}{l}639.18^{* * *} \\
(125.83)\end{array}$ & -- \\
\hline MS & $\begin{array}{c}17.034 \\
(121.25)\end{array}$ & -- & $\begin{array}{l}229.53^{* * *} \\
(123.80)\end{array}$ & -- & WV & $\begin{array}{c}-41.942 \\
(109.57)\end{array}$ & -- & $\begin{array}{l}178.497 \\
(111.27)\end{array}$ & -- \\
\hline $\mathrm{NC}$ & -- & -- & $\begin{array}{l}210.431 \\
(207.09)\end{array}$ & -- & WY & $\begin{array}{l}316.66^{* * * *} \\
(71.448)\end{array}$ & -- & $\begin{array}{l}-110.736 \\
(70.280)\end{array}$ & -- \\
\hline
\end{tabular}

Notes: Standard errors in parentheses. Asymptotic impacts of intervention terms are included in Tables 5.3 and 5.4 in Chapter 5. The year of BSF adoption and first balance were the same for DE, GA, ID, KY, ME, $\mathrm{MO}, \mathrm{NC}, \mathrm{NH}, \mathrm{NV}, \mathrm{RI}, \mathrm{SC}, \mathrm{TN}, \mathrm{VT}$, and WI. 


\section{Appendix E}

Table E1 - Robustness Tests of the Total Balances Model in Table 5.5

\begin{tabular}{|c|c|c|c|c|}
\hline & $\begin{array}{l}\text { Model in } \\
\text { Table 5.5 }\end{array}$ & $\begin{array}{l}\text { Size of } \\
\text { Budget }\end{array}$ & $\begin{array}{c}\text { Weighting by } \\
\text { Budget }\end{array}$ & $\begin{array}{r}\text { P-Value } \\
\text { Model }\end{array}$ \\
\hline Weighting variable & $S E(\hat{\beta})$ & $S E(\hat{\beta})$ & $S E\left(\frac{\hat{\beta}}{\text { Budget }}\right)$ & None \\
\hline Constant & $\begin{array}{c}150.820^{* * *} \\
(56.822)\end{array}$ & $\begin{array}{c}137.550^{* *} \\
(63.818)\end{array}$ & $\begin{array}{c}1.719 \\
(1.081)\end{array}$ & $\begin{array}{c}0.669^{* * * *} \\
(0.119)\end{array}$ \\
\hline Deposit by statutory formula & $\begin{array}{c}32.037 \\
(99.370)\end{array}$ & $\begin{array}{c}38.77 \\
(101.470)\end{array}$ & $\begin{array}{l}2.978 \\
(2.331)\end{array}$ & $\begin{array}{c}0.587 \\
(0.483)\end{array}$ \\
\hline Required deposit by appropriation & $\begin{array}{l}215.430^{*} \\
(134.680)\end{array}$ & $\begin{array}{l}203.410^{*} \\
(124.500)\end{array}$ & $\begin{array}{l}2.002^{*} \\
(1.308)\end{array}$ & $\begin{array}{l}0.361^{* *} \\
(0.175)\end{array}$ \\
\hline Deposit by General Fund Surplus & $\begin{array}{l}-52.761 \\
(62.282)\end{array}$ & $\begin{array}{l}-48.011 \\
(63.760)\end{array}$ & $\begin{array}{l}-0.607 \\
(0.789)\end{array}$ & $\begin{array}{c}0.119 \\
(0.120)\end{array}$ \\
\hline Limit on Forecast Expenditures & $\begin{array}{l}233.820^{*} \\
(129.37)\end{array}$ & $\begin{array}{l}222.340^{*} \\
(133.01)\end{array}$ & $\begin{array}{l}2.757^{*} \\
(1.383)\end{array}$ & $\begin{array}{l}0.327^{*} \\
(0.186)\end{array}$ \\
\hline Withdrawal by statutory formula & $\begin{array}{l}320.950^{*} \\
(164.550)\end{array}$ & $\begin{array}{c}294.880^{*} \\
(175.110)\end{array}$ & $\begin{array}{l}-1.422 \\
(2.499)\end{array}$ & $\begin{array}{l}-0.228 \\
(0.337)\end{array}$ \\
\hline Withdrawal by revenue shortfall & $\begin{array}{c}-102.840^{* * *} \\
(48.524)\end{array}$ & $\begin{array}{c}-100.230^{* *} \\
(49.372)\end{array}$ & $\begin{array}{l}-1.219^{*} \\
(0.677)\end{array}$ & $\begin{array}{l}-0.203^{*} \\
(0.103)\end{array}$ \\
\hline Withdrawal by supermajority & $\begin{array}{c}-11.011 \\
(192.930)\end{array}$ & $\begin{array}{c}-33.313 \\
(200.600)\end{array}$ & $\begin{array}{l}-0.723 \\
(1.642)\end{array}$ & $\begin{array}{l}-0.330^{*} \\
(0.167)\end{array}$ \\
\hline Fund size greater than 5 percent & $\begin{array}{c}59.672 \\
(37.045)\end{array}$ & $\begin{array}{c}54.690 \\
(38.885)\end{array}$ & $\begin{array}{c}0.402 \\
(0.794)\end{array}$ & $\begin{array}{c}0.053 \\
(0.096)\end{array}$ \\
\hline Size of the 1996 budget & -- & $\begin{array}{c}0.002 \\
(0.005) \\
\end{array}$ & -- & -- \\
\hline Sample size & 44 & 44 & 44 & 44 \\
\hline F-Test (Model) & $6.11^{* * *}$ & $5.34^{* * * *}$ & $2.51^{* *}$ & $2.00^{*}$ \\
\hline$R^{2}$ & 0.582 & 0.585 & 0.361 & 0.315 \\
\hline
\end{tabular}

Notes: Standard errors in parentheses. Significance levels are as follows: ${ }^{* * *}$ denotes significance at the 1 percent level, ${ }^{* *}$ at the 5 percent level, and ${ }^{*}$ at the 10 percent level. 


\section{References}

Abrams, B. and W. Dugan, 1986. "The Costs of Constitutional Restraints on Government Spending," Public Choice 49(2), 101-116.

Advisory Commission on Intergovernmental Relations (ACIR), 1987. Fiscal Discipline in the Federal System: Experience of the States, Washington D.C.

Advisory Commission on Intergovernmental Relations (ACIR), 1990. 1988 State Fiscal Capacity and Effort, Washington, DC.

Alesina, A. and T. Bayoumi, 1996. "The Costs and Benefits of Fiscal Rules: Evidence from the U.S. States," NBER Working Paper No. 5614.

Alt, J.E. and R.C. Lowry, 1994. "Divided Government and Budget Deficits: Evidence from the States," American Political Science Review 88, 811-828.

Asdrubali, P., B.E. Sorenson and O.Yosha, 1996. "Channels of Interstate Risksharing: United States 1963-1990," Quarterly Journal of Economics 111, 1081-1110.

Athanasoulis, S. and E. van Wincoop, 1998. "Risksharing Within the United States: What have Financial Markets and Fiscal Federalism Accomplished?" Federal Reserve Bank of New York Working Paper No. 9808.

Avery, R., L. Hansen and V. Hotz, 1983. "Multiperiod Probit Models and Orthogonality Condition Estimation," International Economic Review 24, 21-35.

Bails, D., 1990. "The Effectiveness of Tax-Expenditure Limitations: A Re-evaluation," American Journal of Economics and Sociology 49(2), 223-238.

Barr, J.L. and O.A. Davis, 1966. "An Elementary Political and Economic Theory of the Expenditures of Local Governments," Southern Economic Journal 33, 149-165.

Barro, R, 1979. "On the Determination of the Public Debt," Journal of Political Economy 87(5), 940-971.

Bayoumi, T., M. Goldstein and G. Woglom, 1995. "Do Credit Markets Discipline Sovereign Borrowers? Evidence from U.S. States," Journal of Money, Credit, and Banking 27(4), 1046-1059.

Bertschek, I., and M. Lechner, 1998. "Convenient Estimators for the Panel Probit Model," Journal of Econometrics 87, 329-371.

Bergstrom, T.C. and R.P Goodman, 1973. "Private Demands for Public Goods," American Economic Review 63, 280-296. 
Bohn, H. and R.P. Inman, 1996. "Balanced Budgets and Public Deficits: Evidence from the U.S. States," NBER Working Paper No. 5533.

Box, G., and G. Jenkins, 1976. Time Series Analysis, Forecasting, and Control. Holden Day.

Buchanan, J.M, 1990. "The Domain of Constitutional Economics," Constitutional Political Economy 1(1), 1-18.

Bunch, B.S., 1991. "The Effect of Constitutional Debt Limits on State Governments' Use of Public Authorities," Public Choice 68, 57-69.

Butler, J.S. and R. Moffitt, 1982. "A Computationally Efficient Quadrature Procedure for the One-Factor Multinomial Probit Model," Econometrica 50(3), 761-764.

Cox, J. and D. Lowery, 1990. "The Impact of the Tax Revolt Era State Fiscal Caps," Social Science Quarterly 71(3), 492-590.

Dahlberg, M. and T. Lindstrom, 1998. "Are Local Governments Governed by Forward Looking Decision Makers?" Journal of Urban Economics 44, 254-271.

Davis, O.A. and G.H. Hines, Jr., 1966. "A Political Approach to a Theory of Public Expenditures: The Case of Municipalities," National Tax Journal 19, 259-275.

Dickey, D.A. and W.A. Fuller, 1979. "Distribution of the Estimators for Autoregressive Time Series with a Unit Root," Journal of the American Statistical Association 74, 427-431.

Downs, A., 1957. An Economic Theory of Democracy. New York: Harper Row.

Dugan, W., 1988. "The Effects of Tax or Expenditure Limits on State Government," Center for the Study of the Economy and the State, Working Paper No. 54.

Dye, R.F. and T.J. McGuire, 1992. "Sorting Out State Expenditure Pressures," National Tax Journal 45(3), 315-329.

Elder, H.W., 1992. "Exploring the Tax Revolt: An Analysis of the Effects of Tax and Expenditure Limitations," Public Finance Quarterly 20, 47-63.

Enders, W., 1995. Applied Econometric Time Series. John Wiley \& Sons, Inc.

Fisher, R.C., 1996. State and Local Public Finance. Irwin.

Forbes, R., P. Fischer and J. Peterson, 1981. "Recent Trends in Municipal Revenue Bond Financing," in G.C. Kaufman, ed., Efficiency in the Municipal Bond Market: The Use of Tax-Exempt Financing for Private Purposes, JAI Press. 
Gilligan, T.W. and J.G. Matsusaka, 1995. "Deviations from Constituent Interests: The Role of Legislative Structure and Political Parties in the States," Economic Inquiry 33, 383-401.

Gold, S.D., 1983. "Preparing for the Next Recession: Rainy Day Funds and Other Tools for the States," Legislative Finance Paper No. 41, National Conference of State Legislatures.

Gold, S.D., editor, 1995. The Fiscal Crises of the States: Lessons for the Future. Washington, D.C.: Georgetown University Press.

Goldstein, M. and G. Woglom, 1992. "Market-Based Fiscal Discipline in Monetary Unions: Evidence from the US Municipal Bond Market," in Establishing a Central Bank: Issues in Europe and Lessons from the U.S., Matthew B. Canzoneri, Vittorio Grilli, and Paul R. Masson, eds., Cambridge University Press.

Gramlich, E.M., 1991. "The 1991 State and Local Fiscal Crises," Brookings Papers on Economic Activity 2, 249-287.

Gramlich, E.M. and D. Rubinfeld, 1982. "Micro Estimates of Public Spending Demand Functions and Tests of the Tiebout and Median-Voter Hypotheses," Journal of Political Economy, 536-560.

Greene, K.V. and P.J. Nelson, 1994. "Legislative Majorities and Alternative Theories of the Size of Government," Public Finance 49(1), 42-56.

Hill, J., 1999. "Budget Stabilization Fund Opinion/Editorial," [Online], Available from: URL http://www.ost.state.or.us/news/eedbudstab_02031999.htm [Accessed 23 July 1999].

Holcombe, R.G., 1980. "An Empirical Test of the Median Voter Model," Economic Inquiry, 260-274.

Holcombe, R.G., 1989. "The Median Voter Model in Public Choice Theory," Public Choice, 115-125.

Holcombe, R.G. and R.S. Sobel, 1997. Growth and Variability in State Tax Revenue: An Anatomy of State Fiscal Crises. Westport, Connecticut: Greenwood Press.

Holtz-Eakin, D., H.S. Rosen and S. Tuller, 1994. "Intertemporal Analysis of State and Local Government Spending: Theory and Tests," Journal of Urban Economics $35,159-174$.

Husted, T.A. and L.W. Kenny, 1997. "The Effect of the Expansion of the Voting Franchise on the Size of Government," Journal of Political Economy 105(1), 5482. 
Hynes, D.W., 1999. "Saving for a Rainy Day," [Online], Available from: URL http://www.ioc.state.il.us/FiscalFocus/ffmenu.cfm in the February/March edition [Accessed 23 July 1999].

Inman, R., 1983. "The Anatomy of a Fiscal Crises," Business Review, 15-22.

Kiewiet, R.D. and K. Szakaly, 1996. "Constitutional Limits on Borrowing: An Analysis of State Bonded Indebtedness," Journal of Law, Economics, and Organization 12(1), 62-97.

Knight, B., 1998a. "Supermajority Voting Requirements for Tax Increases: Evidence from the States, University of Wisconsin Working Paper.

Knight, B., 1998b. "Fiscal Effects of Unfunded Mandates: Evidence from State Reimbursement Requirements," University of Wisconsin Working Paper.

Knight, B. and A. Levinson, 1999a. "Rainy Day Funds and State Government Savings," National Tax Journal 52(3), 459-472.

Knight, B. and A. Levinson, 1999b. "Fiscal Institutions in U.S. States," in Institutions, Politics and Fiscal Policy, Kluwer Academic Press, forthcoming.

Koford, K.J., 1982. "Centralized Vote-Trading," Public Choice 39(2), 245-268.

Levinson, A., 1998. "Balanced Budgets and Business Cycles: Evidence from U.S. States," National Tax Journal 51(4), 715-732.

Ljung, G. and G. Box, 1978. "On a Measure of the Lack of Fit in Time Series Models," Biometrica 65, 297-303.

Mackinnon, J.G., 1991. "Critical Values for Cointegration Tests," in Long-run Economic Relationships: Readings in Cointegration, in R.F. Engle and C.W.J. Granger, eds., Oxford University Press.

McCleary, R. and R.A. Hay, Jr., 1980. Applied Time Series Analysis for the Social Sciences. Sage Publications, Ltd.

McKelvey, R.D., 1976. "Intransitivities in Multidimensional Voting Models and Some Implications for Agenda Control," Journal of Economic Theory 32, 472-482.

Mills, T.C., 1990. Time Series Techniques for Economists. Cambridge University Press.

Morton, R.B., 1991. "An Analysis of Legislative Inefficiency and Ideological Behavior," Public Choice 69, 211-222. 
National Association of State Budget Officers (NASBO), 1997. Budget Processes in the States, Washington DC.

National Association of State Budget Officers (NASBO), 1996. Legislative Budget Procedures: A Guide to Appropriations and Processes in the States, Commonwealths, and Territories, Washington DC.

National Conference of State Legislators (NCSL), 1998. State Tax and Expenditure Limits, Denver.

Plott, C.R. and M.E. Levine, 1978. "A Model of Agenda Influence on Committee Decisions," American Economic Review 68(1), 146-160.

Pollock, R. and J.P. Suyderhoud, 1986. "The Role of Rainy Day Funds in Achieving Fiscal Stability," National Tax Journal 43(4), 485-497.

Poole, K.T. and H. Rosenthal, 1996. "Are Legislators Ideologues or the Agents of Constituents?" European Economic Review 40, 707-717.

Poterba, J.M., 1994. "State Responses to Fiscal Crises: The Effects of Budgetary Institutions and Politics," Journal of Political Economy 102(4), 799-821.

Poterba, J.M., 1995. "Balanced Budget Rules and Fiscal Policy: Evidence from the States," National Tax Journal 48(3), 329-336.

Poterba, J.M., 1996. "Budget Institutions and Fiscal Policy in the U.S. States," American Economic Review 86(2), 395-400.

Poterba, J.M. and K. Ruben, 1997. "State Fiscal Institutions and the U.S. Municipal Bond Market," in Fiscal Institutions and Fiscal Performance, James Poterba and Jurgen von Hagen, eds., Chicago: Chicago University Press.

Rueben, K., 1995. "Tax Limitations and Government Growth: The Effect of State Tax and Expenditure Limits on State and Local Government," MIT Working Paper, Department of Economics. Cambridge, MA.

Sobel, R.S., 1992. "Political Incentives and Legislative Voting," Journal of Public Finance and Public Choice 10, 171-182.

Sobel, R.S. and R.G. Holcombe, 1996a. "The Impact of State Rainy Day Funds in Easing State Fiscal Crises During the 1990-1991 Recession," Public Budgeting \& Finance, 28-48.

Sobel, R.S. and R.G. Holcombe, 1996b. "Measuring the Growth and Variability of Tax Bases over the Business Cycle," National Tax Journal 49(4), 535-552. 
Sobel, R.S., 1998. "The Political Costs of Tax Increases and Expenditure Reductions: Evidence from State Legislative Turnover," Public Choice 96, 61-79.

Sorenson, B.E. and O. Yosha, 1997. "Income and Consumption Smoothing among US States: Regions or Clubs?" Brown University Working Paper.

Sorenson, B.E. and O. Yosha, 1998. "International Risksharing and European Monetary Unification," Journal of International Economics, forthcoming.

Stansel, D., 1994. "Taming Leviathan: Are Tax and Expenditure Limits the Answer?" Cato Policy Analysis No. 213, Cato Institute, Washington DC.

Stokey, N.M. and R.E. Lucas, Jr., 1989. Recursive Methods in Economic Dynamics, Harvard University Press.

Strazicich, M.C., 1996. "Are State and Provincial Governments Tax Smoothing? Evidence from Panel Data," Southern Economic Journal 62(4), 979-988.

Strazicich, M.C., 1997. "Does Tax Smoothing Differ by the Level of Government: Time Series Evidence from Canada and the United States," Journal of Macroeconomics 19(2), 305-326.

Turnbull, G.K. and P.M. Mitias, 1995. "Which Median Voter," Southern Economic Journal 62(1), 183-191.

U.S. General Accounting Office (GAO), 1993. Balanced Budget Requirements: State Experiences and Implications for the Federal Government, GAO/AFMD-9358BR, Washington DC.

Vogel, R.C. and R.P. Trost, 1979. "The Response of State Government Receipts to Economic Fluctuations and the Allocation of Counter-Cyclical Revenue Sharing Grants," Review of Economics and Statistics 61(3), 389-400.

von Hagen, J., 1991. "A Note on the Empirical Effectiveness of Formal Fiscal Constraints," Journal of Public Economics 44, 199-210.

von Hagen, J., 1998. "Fiscal Policy and Intranational Risk-sharing," Center for European Integration Studies Working Paper.

von Hagen, J. and G.W. Hammond, 1998. Regional Insurance Against Asymmetric Shocks: An Empirical Study for the European Community," The Manchester School 66(3), 331-353.

Weingast, B.R., K.A. Shepsle and C. Johnsen, 1981. "The Political Economy of Benefits and Costs: A Neoclassical Approach to Distributive Politics," Journal of Political Economy 89, 642-664. 